\title{
Synthesis and Cellular Profiling of Diverse Organosilicon Small Molecules
}

\author{
Annaliese K. Franz, Philip D. Dreyfuss, and Stuart L. Schreiber* \\ Howard Hughes Medical Institute \\ Department of Chemistry and Chemical Biology, Harvard University \\ Broad Institute of Harvard and MIT, Program in Chemical Biology \\ Cambridge, MA, 02142 USA
}

\section{Supporting Information}

I. General Methods

II. Methods for High-throughput Screening and Data Analysis

III. Synthetic Methods

IV. Growth Inhibition Assays for Spirocycles (S)-12 and (R)-13

V. X-ray Data for Spirocycle Ester-6I

VI. Representative ${ }^{1} \mathrm{H}$ and ${ }^{13} \mathrm{C}$ NMR Spectra 


\section{General Methods}

Materials. Commercially available reagents were obtained from commercial sources (Aldrich, Strem, Ryan Scientific (Bionet), Chembridge, and ChemDiv) and used without further purification unless indicated otherwise. Indole-2,3-dione (isatin) reagents were purchased from commercial sources or prepared in one step by alkylation. $N$-(2-propynyl)-1H-indole-2,3-dione was purchased from Ryan Scientific, 7-bromo-1,5-dimethylisatin (5b) and tricyclic isatin 5a were purchased from Chembridge, and $N$-(3-iodobenzyl)-isatin was purchased from ChemDiv. Dry solvents were dispensed from a solvent purification system that passes solvents through packed columns ( $\mathrm{THF}$ and $\mathrm{CH}_{2} \mathrm{Cl}_{2}$ : dry neutral alumina; toluene: dry neutral alumina and Q5 reactant; DMF: activated molecular sieves). Anhydrous pyridine and trimethylorthoformate were purchased from Aldrich. 2,6-lutidine was distilled from $\mathrm{CaH}_{2}$ under nitrogen.

The following abbreviations are used throughout: tetrahydrofuran (THF), 2,6-di-tert-butyl-4methylpyridine (DTBMP), methyl-tert-butylether (MTBE), ethyl acetate (EtOAc), acetonitrile (MeCN), N,N-dimethylaminopyridine (DMAP), dimethylformamide (DMF), diisopropylethyl amine (DIPEA).

Solution and Solid Phase Synthesis. All reactions were performed in oven- or flame-dried glassware (including 4, 8 and $20 \mathrm{~mL}$ VWR or Wheaton vials fitted with Teflon-coated or septa caps). Solid phase synthesis was performed using 3-[diisopropyl(p-methoxyphenyl)silyl]propyl functionalized 500-600 um polystyrene (1\% divinylbenzene) macrobeads as loose beads or contained in micro X-kans (Discovery Partners International, now Nexus Biosystems, XK-C096 XMicrokans ${ }^{\mathrm{TM}}$ ) for split pool synthesis without using chemical encoding. Micro X-kans ${ }^{\mathrm{TM}}$ were filled with 28-30 mg of macrobead resin (1.0-1.2 mmol/g loading) to produce approximately 10-18 mg/kan quantities for each compound. Yields are calculated upon cleavage of the final product for multi-step solid phase reactions assuming an average of $0.033 \mathrm{mmol} / \mathrm{kan}$. The silyl-functionalized macrobeads were prepared at the Institute of Chemistry and Chemical Biology (Harvard Medical School) or at the Broad Chemical Biology Program (Broad Institute of Harvard and MIT) according to published procedure. ${ }^{1}$

Purification and Analysis. All ${ }^{1} \mathrm{H},{ }^{13} \mathrm{C},{ }^{19} \mathrm{~F}$, and ${ }^{29} \mathrm{Si}$ spectra were recorded at ambient temperature at 600, 100, 282, or 99 (or 59) MHz, respectively, using a Varian Unity/Inova 600 (600 MHz), Varian Unity/Inova 500 (500 MHz), Varian Mercury 400 (400 MHz), or Varian Mercury 300 (300 MHz) spectrometer. The ${ }^{1} \mathrm{H}$ spectral data are reported as follows: chemical shift in parts per million downfield from tetramethylsilane on the $\delta$ scale, multiplicity (s, singlet; $d$, doublet; t, triplet; q, quartet; s, septet; m, multiplet; dd, doublet of doublets, and b, broadened), coupling constant (Hz), and integration. Carbon NMR chemical shifts are reported in ppm from tetramethylsilane with the solvent reference employed as the internal standard (deuterochloroform $\left(\mathrm{CDCl}_{3}\right)$ at $\left.77.0 \mathrm{ppm}\right)$. Fluorine and silicon NMR chemical shifts are reported in ppm with trifluoroacetic acid or tetramethylsilane employed as an external standard, respectively. IR frequencies are given in $\mathrm{cm}^{-1}$ and spectra were obtained on a Perkin-Elmer Model 2000 FT-IR spectrophotometer.

Several instruments were employed for tandem high performance liquid chromatography/mass spectral (LCMS) analyses. Most analytical separations were performed on a Micromass Platform LCZ mass spectrometer or a Micromass Platform LCT mass spectrometer in either atmospheric pressure chemical ionization (APCI) or electropspray ionization (EI) mode after separation on a Waters Alliance separation module. Most separations were performed on a Waters Symmetry® C18 column $(2.1 \times 50 \mathrm{~mm}, 3.5 \mu \mathrm{m})$ with a flow rate of $0.4 \mathrm{~mL} / \mathrm{min}$ and a $12 \mathrm{~min}$ gradient of $15-100 \% \mathrm{CH}_{3} \mathrm{CN}$ in $\mathrm{H}_{2} \mathrm{O}$, with a constant formic acid buffer using a Waters 996 photodiode array detector. Analytical SFC/MS analyses were performed on a Berger SFC/Waters ZQ MS system in atmospheric pressure 
chemical ionization (APCI) mode. The separations were performed on a Thermo betasil silica column (4.6 x $250 \mathrm{~mm}, 5 \mu \mathrm{m})$ with a flow rate of $4.0 \mathrm{~mL} / \mathrm{min}$ and $10 \%$ methanol modifier (isocratic method), using a Waters 996 photodiode array detector. Chiral separations were performed on a Berger SFC/Waters ZQ MS system with a Chirapak AD column (4.6 x 250 mm, $5 \mu \mathrm{m})$ or an Agilent 1100 HPLC system with a Chiralcel OD column $(4.6$ x $150 \mathrm{~mm}, 5 \mu \mathrm{m})$. High-resolution mass spectra were obtained at the mass spectrometry facility at Harvard University using a mass resolution of 10,000.

When indicated, the progress of reactions was monitored by analytical thin layer chromatography using glass plates pre-coated with Merck silica get 60 F254 and visualized with UV light. Flash chromatography was performed either on EM Science silica gel 60 (230-400 mesh) or using a CombiFlash Companion system (Teledyne ISCO, Inc.) with pre-packed FLASH silica columns (Biotage, Inc.).

Small Molecule Screening. Multidimensional screening was performed at the Broad Chemical Biology (BCB) Screening Platform (Eli \& Edith Broad Institute of Harvard and MIT). Compounds for screening were prepared as DMSO stock solutions (either 10 or $15 \mathrm{mM}$ ) and screened in 384-well plates in duplicate assay experiments. In between use of compounds for different screening experiments, the compound plate is dried in vacuo using a Genevac ${ }^{\mathrm{TM}} \mathrm{HT}-12$ centrifugating vacuum chamber, sealed and stored at $-20{ }^{\circ} \mathrm{C}$. Mammalian cells were cultured in a humidified environment with $5 \% \mathrm{CO}_{2}$ at $37^{\circ} \mathrm{C}$ (standard tissue culture techniques).

\section{Methods for High-throughput Screening and Data Analysis}

High-throughput screening. The screens presented here were not selected based on a specific criteria for this work, rather the 41 screens described here represent all of the HTS projects to which the compounds described in this paper were exposed at the Broad Chemical Biology Screening Platform from November 2005 to July 2006 (note: this data does not include any of the small molecule microarray or high-content image-based screening performed). As such, the 41 assays represent diverse screening projects using whole cells (mammalian cell lines), whole organisms (yeast, bacteria), and pure proteins that are relevant to cancer, developmental biology, infectious disease and psychiatric disease (Figure S-1 and Table S-1). For example, these assays include readouts of cell viability (mitochondrial potential and intracellular reducing equivalents), chemical-genetic modifier screens, reporter gene function, protein-DNA binding, enzyme activity, and other relevant screens. Cell-based assays were performed using antibody-based cytoblot, fluorescent dyes, and other methods that have been used extensively in HTS of small-molecule collections. For the purpose of this work, the existing BCB screening data from 41 assay experiments was mined to provide a global analysis of the biological activity of these organosilicon small molecules. The individual screening experiments, the computational details of data normalization and global analysis, and the details of the specific biological activity for active compounds will be reported separately.

In order to establish a distribution based on mock treatment, an additional 384-well plate of baseline controls (DMSO) was employed for each replicate, in addition to the DMSO-only control wells that were incorporated into each compound assay plate. Aliquots of compound stock solutions in DMSO were transferred from compound plates to each assay plate using an automated pin-based compound transfer robot (CyBio $\mathrm{CyBi}^{\mathrm{TM}}$-Well). The final concentration of the compound assayed was dependent on the specific details of each of the 41 assays performed, but typically the final compound concentration was $20 \mu \mathrm{M}$ for experiments with mammalian cell lines and $100 \mu \mathrm{M}$ for experiments with yeast strains. The screening data from multiple assays was normalized as described below and in detail 
elsewhere. ${ }^{2}$ Compounds identified to have activity in primary HTS have been retested to confirm activity.
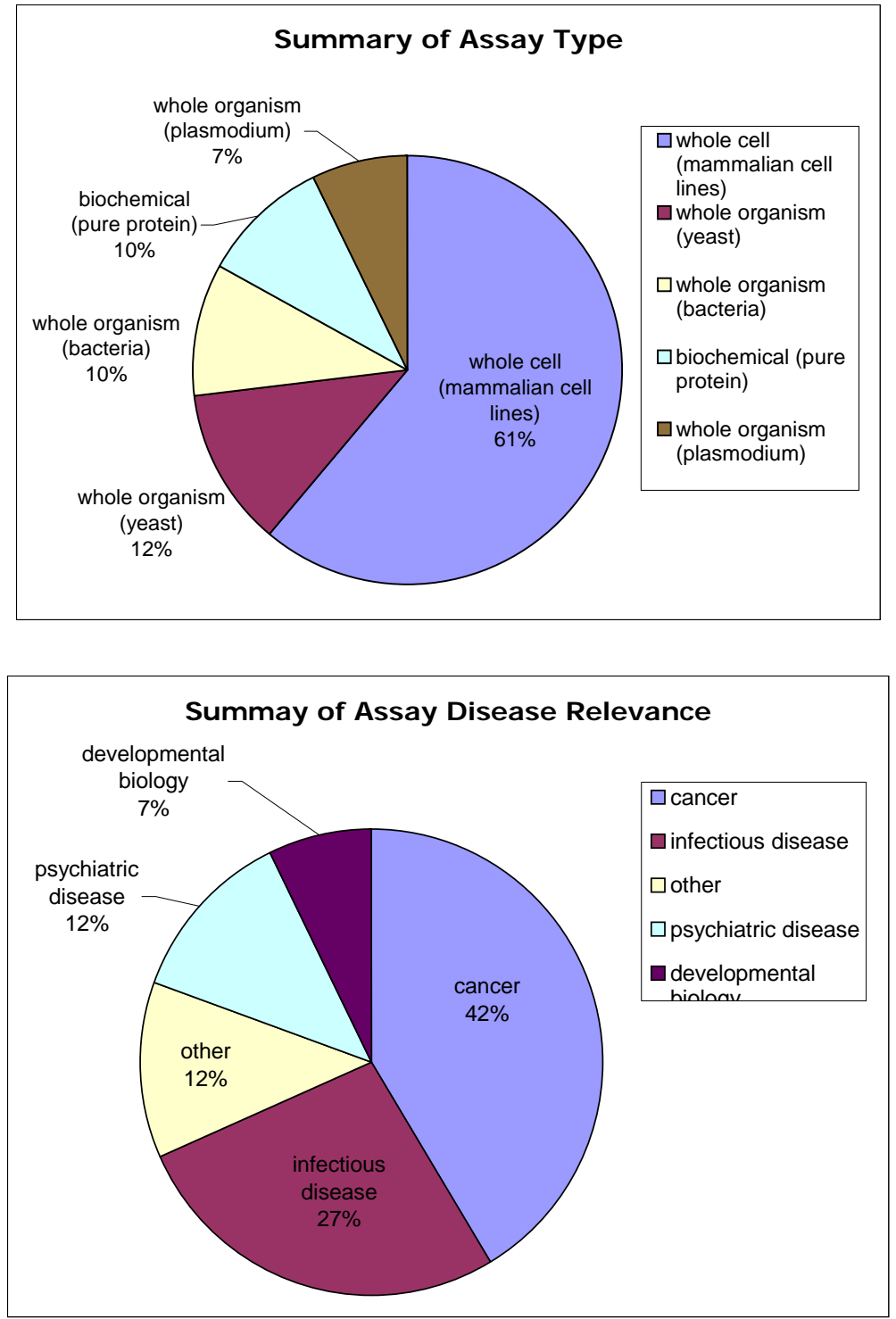

Figure S-1. Summary of the panel of 41 BCB assays based on disease relevance and assay type. The "other" category includes assays such as annotation for counter screens, genomic profiling and more fundamental aspects of biology that are related to several/many areas of disease biology. 
Table S-1. Description of type, biological object, and disease relevance for the 41 BCB assays. Assay number 6 and 7 refer to A549 and HepG2 cell viability assays, respectively, described in more detail for the secondary screening of compounds $(S)-\mathbf{1 2}$ and $(R)-\mathbf{1 3 .}$

\begin{tabular}{|c|c|c|c|}
\hline Assay number & Assay Type & Biological Object & Disease Relevance \\
\hline 1 & whole cell & mammalian cell line & cancer \\
\hline 2 & whole cell & mammalian cell line & cancer \\
\hline 3 & whole cell & mammalian cell line & cancer \\
\hline 4 & whole cell & mammalian cell line & cancer \\
\hline 5 & whole cell & mammalian cell line & cancer \\
\hline 6 & whole cell & mammalian cell line & cancer \\
\hline 7 & whole cell & mammalian cell line & cancer \\
\hline 8 & whole cell & mammalian cell line & cancer \\
\hline 9 & whole cell & mammalian cell line & cancer \\
\hline 10 & whole cell & mammalian cell line & cancer \\
\hline 11 & whole cell & mammalian cell line & cancer \\
\hline 12 & whole cell & mammalian cell line & cancer \\
\hline 13 & whole cell & mammalian cell line & cancer \\
\hline 14 & whole cell & mammalian cell line & cancer \\
\hline 15 & whole cell & mammalian cell line & cancer \\
\hline 16 & whole cell & mammalian cell line & developmental biology \\
\hline 17 & whole cell & mammalian cell line & developmental biology \\
\hline 18 & whole cell & mammalian cell line & infectious disease \\
\hline 19 & whole cell & mammalian cell line & infectious disease \\
\hline 20 & whole cell & mammalian cell line & psychiatric disease \\
\hline 21 & whole cell & mammalian cell line & psychiatric disease \\
\hline 22 & whole cell & mammalian cell line & psychiatric disease \\
\hline 23 & whole cell & mammalian cell line & psychiatric disease \\
\hline 24 & whole cell & mammalian cell line & psychiatric disease \\
\hline 25 & whole cell & mammalian cell line & other \\
\hline 26 & whole cell & organism: yeast & cancer \\
\hline 27 & whole cell & organism: yeast & cancer \\
\hline 28 & whole cell & organism: yeast & other \\
\hline 29 & whole cell & organism: yeast & other \\
\hline 30 & whole cell & organism: yeast & other \\
\hline 31 & whole cell & organism: plasmodium & infectious disease \\
\hline 32 & whole cell & organism: plasmodium & infectious disease \\
\hline 33 & whole cell & organism: plasmodium & infectious disease \\
\hline 34 & whole cell & organism: bacteria & infectious disease \\
\hline 35 & whole cell & organism: bacteria & infectious disease \\
\hline 36 & whole cell & organism: bacteria & infectious disease \\
\hline 37 & whole cell & organism: bacteria & infectious disease \\
\hline 38 & biochemical & protein & other \\
\hline 39 & biochemical & protein & infectious disease \\
\hline 40 & biochemical & protein & infectious disease \\
\hline 41 & biochemical & protein & developmental biology \\
\hline
\end{tabular}


Analysis of HTS data. Standard methods for data analysis of multidimensional screening based on HTS assays with different read-outs have been developed at the Broad Institute. Assay measurements were made within the linear range of instrument detection to promote the validity of an assumption of mock-distribution symmetry. To account for plate-to-plate variation in signal, median raw values of control well signals were first subtracted from all raw values (i.e., control measurements and compound measurements) on the same plate, providing a common distribution centroid (approaching zero) for all plates in one experiment, which we define as a collection of distinct probe source plates (e.g., a multi-microtiter plate library) ${ }^{3}$ exposed to the same assay conditions. Next, the (now-relative) values for all control measurements in the experiment were collected together, and values failing Chauvenet's criterion ${ }^{4}$ for this overall distribution were discarded to protect against the overcontribution of edge effects and other systematic artifacts, known to present a technical problem for microtiter plate experiments. ${ }^{5}$ The standard deviation of the distribution derived from the remaining control measurements was used as a per-experiment normalization value to evaluate independently each background-subtracted value for a compound measurement in that experiment. By dividing background-subtracted compound measurements by this normalization value, each compound was assigned a score, intuitively similar to a Z-score, along a dimensionless measurement axis that corresponds to the confidence that the measurement can not be explained by assay noise. To normalize screening data from multiple assays, each compound was independently assigned such a signed Zscore (i.e., "+" or "-“) corresponding to the number of standard deviations it fell above or below the mean of a well-defined mock-treatment distribution (vida supra). Experiments were performed in two technical replicates (A and B), and thus each compound was independently assigned two such Z-scores under each measurement condition. To combine the replicates, a composite Z-score was calculated by scaling the vector $\left[Z_{\mathrm{A}}, Z_{\mathrm{B}}\right]$ by the cosine correlation with a vector corresponding to "perfect reproducibility" (i.e., equal Z-scores in both replicates). The resulting collection of composite Z-scores represents the primary dataset to be used for further analysis. This normalization procedure is similar to earlier work at the Broad Institute and the full computational details will be presented elsewhere. ${ }^{2}$ Data visualization for compound signatures and profile analysis was performed using Spotfire Decision Site 7.0 (Spotfire, Inc.; Somerville, MA).

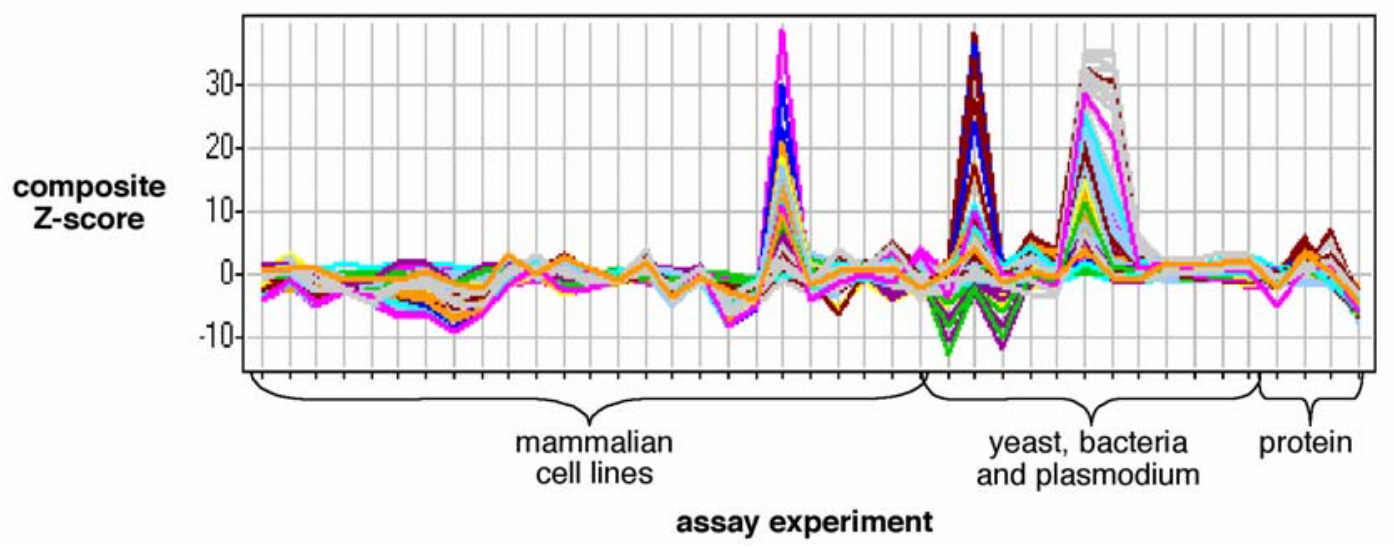

Figure S-2. Global view of compound signatures shown for 90 compounds in the panel of 41 assay experiments. The horizontal axis indicates the assay experiment number (as detailed in Table S-1) and the vertical axis shows the performance of the compound in each assay, based on the composite Zscore for duplicate assay experiments. The individual cellular profiles for representative compounds are included with the characterization data for each compound, with the R-enantiomer shown on the left and the S-enantiomer shown on the right. 


\section{Synthetic Methods}

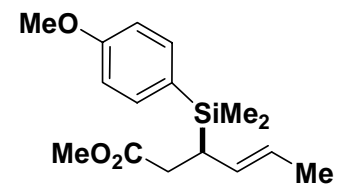

(R,E)-methyl-3-((4-methoxyphenyl)dimethylsilyl)hex-4-enoate ( $R$-1). Chlorodimethylsilane (12.00 g, $0.126 \mathrm{~mol}$ ) was dissolved in $60 \mathrm{~mL}$ of THF in a $500-\mathrm{mL}$ round bottom and cooled to $0{ }^{\circ} \mathrm{C}$. A solution of 4-methoxyphenylmagnesium bromide (0.152 mol, $0.5 \mathrm{M}$ in THF) was added drop-wise slowly over 15 min while stirring. The reaction mixture was allowed to warm to $23{ }^{\circ} \mathrm{C}$ and stirred for $16 \mathrm{~h}$. Then the reaction mixture was quenched with $\mathrm{NH}_{4} \mathrm{Cl}$ (sat. aq.) and partitioned with $100 \mathrm{~mL}$ of MTBE. The organic layer was separated and the aqueous layer was extracted with $3 \times 100 \mathrm{~mL}$ of MTBE. The combined organic layers were dried $\left(\mathrm{Na}_{2} \mathrm{SO}_{4}\right)$ and concentrated in vacuo. Analysis of the unpurified dimethyl(4-methoxphenyl)silane reagent using ${ }^{1} \mathrm{H}$ NMR spectroscopy demonstrated sufficient purity to be employed directly in the next reaction.

The procedure outlined follows the route previously reported by Panek and co-workers. ${ }^{6} \mathrm{~A}$ solution of racemic 3-butyn-2-ol (9.3 mL, $0.126 \mathrm{~mol})$ of was dissolved in $150 \mathrm{~mL}$ of THF in a 500-mL round bottom flask equipped with a reflux condenser under positive nitrogen pressure. Dimethyl(4methoxphenyl)silane (approximately $0.126 \mathrm{~mol}$ from the above reaction) and a small piece of sodium metal (ca. $5 \mathrm{mg}$ ) were added to the reaction mixture. The solution was stirred for $15 \mathrm{~min}$ and then 2.50 $\mathrm{mL}(0.7 \mathrm{mmol})$ of bis( $\eta$-divinyltetramethyldisiloxane)tri-tert-butylphosphineplatinum(0) (3\% solution in xylenes) was added. The reaction mixture was then heated under reflux for $12 \mathrm{~h}$, during which time the solution became a dark brown color. The solution was allowed to cool to $23^{\circ} \mathrm{C}$ and the solvent was removed under reduced pressure to yield a crude orange residue containing (E)-4-(dimethyl(4methoxyphenyl)silyl)but-3-en-2-ol. Analysis of the unpurified oil using ${ }^{1} \mathrm{H}$ NMR spectroscopy demonstrated sufficient purity to be directly employed in the next reaction; ${ }^{1} \mathrm{H}$ NMR (500 $\mathrm{MHz}$, $\left.\mathrm{CDCl}_{3}\right) \delta 7.44$ (d, $\left.J=8.8 \mathrm{~Hz}, 2 \mathrm{H}\right), 6.92$ (d, $\left.J=8.8 \mathrm{~Hz}, 2 \mathrm{H}\right), 6.15$ (dd, $\left.J=3.7,18.7 \mathrm{~Hz}, 1 \mathrm{H}\right), 5.95$ (dd, $J$ = 1.1, $18.7 \mathrm{~Hz}, 1 \mathrm{H}), 4.31(\mathrm{t}, J=5.9 \mathrm{~Hz}, 1 \mathrm{H}), 3.81(\mathrm{~s}, 3 \mathrm{H}), 1.65$ (s, $1 \mathrm{H}), 1.27$ (d, $J=6.6 \mathrm{~Hz}, 3 \mathrm{H}), 0.33$ (s, 6H); ${ }^{13} \mathrm{C}$ NMR (100 MHz, $\left.\mathrm{CDCl}_{3}\right) \delta 160.4,151.1,135.2,129.2,126.3,113.6,70.4,55.0,22.9,-2.5$.

Racemic (E)-4-(dimethyl(4-methoxyphenyl)silyl)but-3-en-2-ol (18.5g, approximately 0.073 mol from the above reaction) was directly dissolved in $300 \mathrm{~mL}$ of pentanes in a $500-\mathrm{mL}$ round bottom flask. Lipase Amano AK (9.25 g, 0.5 equiv by weight) and vinyl acetate (18.6 mL, $201.8 \mathrm{mmol}$ ) were added. The reaction mixture was stirred at $23^{\circ} \mathrm{C}$ and after $4 \mathrm{~h}$ the reaction progress was monitored by removing aliquots to compare the ${ }^{1} \mathrm{H}$ NMR proton integration for the $(S)$-alcohol (m, $1 \mathrm{H}$ at $\left.4.34 \mathrm{ppm}\right)$ and $(R)$-acetate $(\mathrm{m}, 1 \mathrm{H}$ at $5.38 \mathrm{ppm})$ products. The reaction was determined to be complete when the integration is a 1:1 ratio, and the reaction mixture was filtered through a fritted funnel to remove the lipase enzyme. The filtrate was concentrated in vacuo and the residue was purified by flash chromatography (EtOAc/hexanes) to separate the $(S)$-alcohol and $(R)$-acetate products. The $(S)$-alcohol was used directly in the subsequent Johnson ortho ester Claisen reaction to afford (S,E)-3-((4methoxyphenyl)dimethylsilyl)hex-4-enoate, while the $(R)$-acetate was reduced with $\mathrm{LiAlH}_{4}$ to afford the $(R)$-alcohol, and then used directly in the Johnson ortho ester Claisen reaction to afford $(R, E)$ methyl 3-((4-methoxyphenyl)dimethylsilyl)hex-4-enoate.

A stirred solution of $7.62 \mathrm{~g}$ (32.3 mmol) (R,E)-4-((4-methoxyphenyl)dimethylsilyl)but-3-en-2ol in $60 \mathrm{~mL}$ of dry toluene in a $250 \mathrm{~mL}$ round bottom flask equipped with a reflux condenser was treated with $16.4 \mathrm{~mL}$ (129.2 mmol) of trimethyl orthoacetate and $0.168 \mathrm{~mL}$ (2.26 mmol, 0.07 equiv) of propionic acid. The reaction mixture was heated under reflux for $48 \mathrm{~h}$ and then allowed to cool to $23^{\circ} \mathrm{C}$. The solution was concentrated in vacuo leaving the crude (R,E)-methyl-3-((4methoxyphenyl)dimethylsilyl)hex-4-enoate $(R-1)$ as a yellow oil. The crude residue was purified by 
flash chromatography (gradient elution 5\% EtOAc/hexanes) to yield the product as a yellow oil (8.52g, $80 \%$ yield over 3-4 steps): ${ }^{1} \mathrm{H}$ NMR $\left(500 \mathrm{MHz}, \mathrm{CDCl}_{3}\right) \delta 7.39(\mathrm{t}, J=8.8 \mathrm{~Hz}, 2 \mathrm{H}), 6.90(\mathrm{~d}, J=8.8 \mathrm{~Hz}$, 2H), 5.27 (m, 2H), 3.82 (s, 3H), 3.58 (s, 3H), 2.14-2.35 (m, 3H), 1.63 (d, J = 4.8 Hz, 3H), 0.25 (s, 6H); ${ }^{13} \mathrm{C}$ NMR $\left(100 \mathrm{MHz}, \mathrm{CDCl}_{3}\right) \delta 174.0,160.5,135.4,130.0,127.6,123.6,113.5,55.0,51.4,34.3,29.0$, $18.1,-4.4,-5.3$.

Confirmation of enantiomeric purity for crotylsilane (R)-1 and (S)-1: HPLC analysis was performed on an Agilent 1100 HPLC system using a Chiralcel OD column (4.6 x $150 \mathrm{~mm}, 5 \mu \mathrm{m})$ with 1\% IPA/hexanes (isocratic) and a flow rate of $1.0 \mathrm{~mL} / \mathrm{mim}: \mathrm{t}_{\mathrm{r}}=4.82 \mathrm{~min}$ for $(S)$-enantiomer, and $\mathrm{t}_{\mathrm{r}}=5.44$ min for $(R)$-enantiomer.

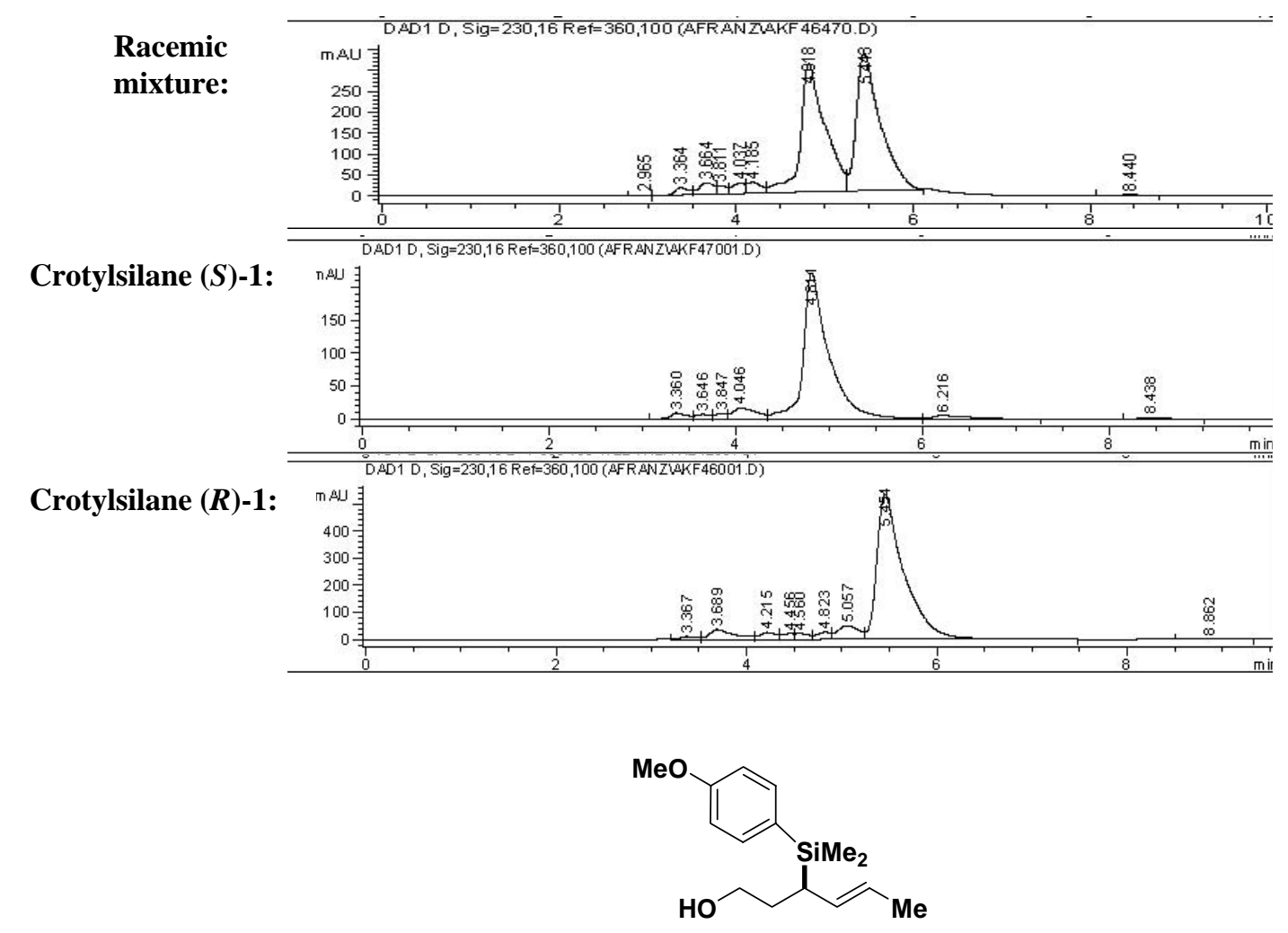

(R,E)-3-((4-methoxyphenyl)dimethylsilyl)hex-4-en-1-ol (3a). Lithium aluminum hydride (0.168 g, $4.45 \mathrm{mmol}$ ) was dissolved in $8 \mathrm{ml}$ of $\mathrm{Et}_{2} \mathrm{O}$. The reaction mixture was cooled to $0^{\circ} \mathrm{C}$ and a solution of (E)-methyl 3-((4-methoxyphenyl)dimethylsilyl)hex-4-enoate (1) (1.0g, $3.42 \mathrm{mmol})$ in $4 \mathrm{~mL}$ of $\mathrm{Et}_{2} \mathrm{O}$ was added drop-wise. The reaction was allowed to warm to $23{ }^{\circ} \mathrm{C}$ and then stirred for one hour. Then

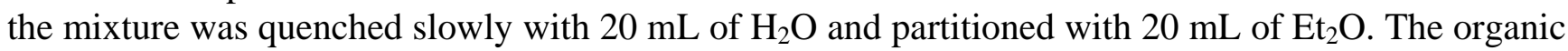
layer was separated, dried $\left(\mathrm{Na}_{2} \mathrm{SO}_{4}\right)$ and concentrated in vacuo to yield crotylsilane alcohol $(R)-3 \mathbf{a}$ as a colorless oil (0.896 g, 92\%). Analysis of the unpurified oil using ${ }^{1} \mathrm{H}$ NMR spectroscopy demonstrated sufficient purity to be employed directly in the macrobead loading: ${ }^{1} \mathrm{H}$ NMR $\left(500 \mathrm{MHz}, \mathrm{CDCl}_{3}\right) \delta 7.41$ (d, $J=8.6 \mathrm{~Hz}, 2 \mathrm{H}), 6.91$ (d, $J=8.6 \mathrm{~Hz}, 2 \mathrm{H}), 5.29$ (m, 2H), 3.81 (s, 3H), 3.62 (ddd, $J=10.6,7.0,5.1$ $\mathrm{Hz}, 1 \mathrm{H}$ ), 3.53 (td, $J=10.6,7.2,6.9 \mathrm{~Hz}, 1 \mathrm{H}), 1.76$ (ddd, $J=12.0,8.9,2.8 \mathrm{~Hz}, 1 \mathrm{H}), 1.66$ (d, $J=5.4 \mathrm{~Hz}$, 3H), 1.51 (ddt, $J=12.0,6.3,5.2 \mathrm{~Hz}, 1 \mathrm{H}), 0.25$ (s, 3H), $0.24(\mathrm{~s}, 3 \mathrm{H}) ;{ }^{13} \mathrm{C} \mathrm{NMR}\left(125 \mathrm{MHz}, \mathrm{CDCl}_{3}\right) \delta$ 160.2, 135.3, 131.3, 128.3, 123.6, 113.3, 62.7, 54.9, 31.7, 29.4, 18.0, -4.3, -5.2. 
General procedure for modified loading of macrobeads with alcohol substrate. The procedure outlined follows the loading method previously reported by Schreiber and co-workers, ${ }^{1}$ with the modification to the trifluoromethanesulfonic acid treatment. For loading small amounts (200 mg or less) or 1-2 X-Kans of resin, a fritted PD-10 column equipped with a rubber septum and a three-way teflon stopcock is employed for draining solution and rinsing the resin. For larger loading reactions, a round-bottom flask equipped with a rubber septum and cannula is employed for draining solution and rinsing the resin.

Prior to loading, macrobeads were dried in vacuo for 12-24 h. After swelling the resin in $\mathrm{CH}_{2} \mathrm{Cl}_{2}$ (sufficient to cover the loose beads or X-Kans) under an argon atmosphere for $15 \mathrm{~min}$, a solution of trifluoromethanesulfonic anhydride (0.5 equiv, $0.2 \mathrm{M}$ in $\mathrm{CH}_{2} \mathrm{Cl}_{2}$ ) was added and incubated

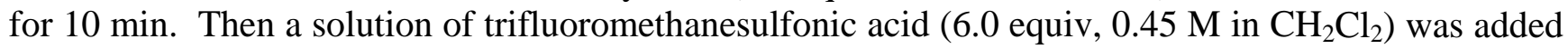
and the beads were allowed to stand with occasional agitation for $10 \mathrm{~min}$. The solution becomes orangish-red colored during this time. Then the trifluoromethanesulfonic acid solution was drained and the beads were rinsed twice with $\mathrm{CH}_{2} \mathrm{Cl}_{2}$. After rinsing, fresh $\mathrm{CH}_{2} \mathrm{Cl}_{2}$ was added (sufficient to cover the loose beads or X-Kans), and the resin is treated with 2,6-lutidine (8.0 equiv) and swirled gently until the red color disappears (approx. 1-2 min). (Note: if a PD-10 column is being used, the reaction vessel should be vented before proceeding to the next step) Then a solution of alcohol (2.0 equiv) was added and the beads are incubated for 8-12 h with gentle agitation on an IKA orbital shaker. The alcohol can be added neat if the reagent is a liquid, or as a solution in $\mathrm{CH}_{2} \mathrm{Cl}_{2}$ if the reagent is a solid. In the case of alcohols with limited solubility, a solution in DMF can be employed. Once the reaction is completed, the solution is drained and the resin is washed using the following protocol: $\mathrm{CH}_{2} \mathrm{Cl}_{2}(3 \mathrm{x}$ $15 \mathrm{~min}$ ), $\mathrm{MeCN}$ ( $3 \times 15 \mathrm{~min}$ ), and $\mathrm{CH}_{2} \mathrm{Cl}_{2}$ ( $3 \times 15 \mathrm{~min}$ ). The beads were dried under a gradual vacuum (house vacuum) for $1 \mathrm{~h}$, and then dried under high vacuum for 12-24 h. Loading can be checked using on-bead analysis with magic angle spinning (MAS) ${ }^{1} \mathrm{H}$ NMR spectroscopy, or by HF/pyridine cleavage and solution analysis with LCMS or ${ }^{1} \mathrm{H}$ NMR spectroscopy. Based on mass recovery and conversion (as determined using LCMS and ${ }^{1} \mathrm{H}$ NMR spectropscopy), the average loading levels were determined to be $80-90 \%$, based on the assumption that $100 \%$ of the material loaded onto the macrobeads was cleaved and recovered.

General procedure for Si-O cleavage of compound from solid phase. Using a Teflon microcentrifuge eppendorf tube or Teflon vial, resin was swollen in THF $(1.0 \mathrm{~mL}$ for each $30 \mathrm{mg}$ of resin) and then a solution of HF-pyridine $(0.100 \mathrm{~mL}$ for each $30 \mathrm{mg}$ of resin) was added. The reaction mixture was agitated for $3 \mathrm{~h}$ on an IKA orbital shaker shaker. Then ethoxytrimethylsilane (TMSOEt, $0.50 \mathrm{~mL}$ for each $30 \mathrm{mg}$ of resin) was added to quench the excess $\mathrm{HF}$ and the resin was further agitated for $1 \mathrm{~h}$. The solution was transferred to a collection vial and the beads were extracted with THF ( $4 \mathrm{x}$ $15 \mathrm{~min})$. The combined extracts were concentrated in vacuo, and the residue was redissolved for analysis by LMCS.

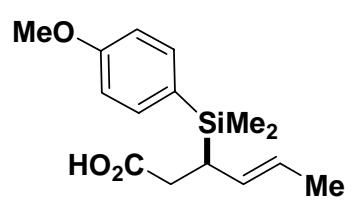

$(R, E)$-3-((4-methoxyphenyl)dimethylsilyl)hex-4-enoic acid. The procedure and characterization details are provided for the synthesis of the $(R)$-crotylsilane acid from the $(R)$-crotylsilane ester $(\mathbf{1})$. The same procedure was followed using the crotylsilane ester $(S)-\mathbf{1}$ to afford the $(S)$-crotylsilane acid. $(R, E)$-methyl 3-((4-methoxyphenyl)dimethylsilyl)hex-4-enoate $(R-\mathbf{1}) \quad(7.30 \mathrm{~g}, \quad 25.0 \mathrm{mmol})$ was dissolved in $100 \mathrm{~mL}$ of EtOH/H2O (2:1). Then $\mathrm{NaOH}$ (3.00 g, $75.0 \mathrm{mmol}$ ) was added and the reaction 
was stirred at $23^{\circ} \mathrm{C}$ for $5 \mathrm{~h}$. Once TLC indicated that the starting material was consumed, the solution was concentrated in vacuo, acidified to $\mathrm{pH} 2.0$ and then extracted with $\mathrm{CH}_{2} \mathrm{Cl}_{2}$. The organic layer was separated, dried $\left(\mathrm{Na}_{2} \mathrm{SO}_{4}\right)$ and concentrated in vacuo to yield a yellow oil. The acid was purified on $\mathrm{SiO}_{2}$ using an ISCO purification system, eluted in 10-20\% EtOAc/hexanes to yield the product as a yellowish solid with sufficient purity to be used directly in the amide formation reaction (5.60 g, 81\%): ${ }^{1} \mathrm{H}$ NMR (500 MHz, $\left.\mathrm{CDCl}_{3}\right) \delta 10.98$ (bs, $\left.1 \mathrm{H}\right), 7.41$ (d, $\left.J=8.6 \mathrm{~Hz}, 2 \mathrm{H}\right), 6.92$ (d, $J=8.6 \mathrm{~Hz}$, 2H), 5.31 (m, 2H), 3.82 (s, 3H), 2.37 (dd, $J=15.4,4.0 \mathrm{~Hz}, 1 \mathrm{H}$ ), 2.29 (dd, $J=15.4,11.2 \mathrm{~Hz}, 1 \mathrm{H}$ ), 2.16 (ddd, $J=11.2,6.3,3.8 \mathrm{~Hz}, 1 \mathrm{H}), 1.65$ (d, $J=4.9 \mathrm{~Hz}, 3 \mathrm{H}), 0.27(\mathrm{~s}, 6 \mathrm{H}) ;{ }^{13} \mathrm{C}$ NMR $\left(125 \mathrm{MHz}, \mathrm{CDCl}_{3}\right) \delta$ 179.9, 160.5, 135.4, 129.6, 127.4, 123.8, 113.5, 54.9, 34.2, 28.6, 18.1, -4.3, -5.3.

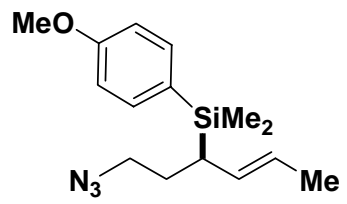

(R,E)-(1-azidohex-4-en-3-yl)(4-methoxyphenyl)dimethylsilane. The procedure and characterization details are provided for the synthesis of the $(R)$-crotylsilane azide from the $(R)$-crotylsilane alcohol 3a. The same procedure was followed using the crotylsilane alcohol $(S)$-3a to afford the $(S)$-crotylsilane azide. (R,E)-3-((4-methoxyphenyl)dimethylsilyl)hex-4-en-1-ol (3a) was first converted to the tosylate reagent. A solution of alcohol $3 a(1.00 \mathrm{~g}, 3.79 \mathrm{mmol})$ was dissolved in $10 \mathrm{~mL}$ of $\mathrm{CH}_{2} \mathrm{Cl}_{2}$ and cooled to $0^{\circ} \mathrm{C}$. Then triethylamine $(0.845 \mathrm{~mL}, 6.06 \mathrm{mmol})$, tosyl chloride $(0.866 \mathrm{~g}, 4.54 \mathrm{mmol})$ and catalytic DMAP were added. The reaction was stirred at $0^{\circ} \mathrm{C}$ for $15 \mathrm{~min}$ and then allowed to slowly warm to room temperature, at which time TLC confirmed that the reaction was complete. The reaction was portioned with $20 \mathrm{~mL}$ of water and then the aqueous layers were extracted with $\mathrm{CH}_{2} \mathrm{Cl}_{2}(3 \times 10 \mathrm{~mL})$. The combined organic layers were dried $\left(\mathrm{Na}_{2} \mathrm{SO}_{4}\right)$ and concentrated in vacuo to yield a yellow oil, which was used directly in the next step without further purification.

The unpurified tosylate reagent (estimated to be $3.79 \mathrm{mmol}$ from the above reaction) was dissolved in $15 \mathrm{~mL}$ of DMF and treated with sodium azide $(0.364 \mathrm{~g}, 5.6 \mathrm{mmol})$ to afford a white slurry that was stirred overnight for 8-12 h. At this time, the solvent mixture was removed in vacuo and the crude material was loaded directly onto a column (silica) and filtered/eluted in 100\% hexanes to yield the product as a colorless oil $(0.816 \mathrm{~g}, 74 \%)$ with sufficient purity to be used directly in the coppercatalyzed azide-alkyne cycloaddition reaction. The azide should be prepared and used immediately to avoid decomposition. ${ }^{1} \mathrm{H}$ NMR $\left(600 \mathrm{MHz}^{\mathrm{CDCl}}{ }_{3}\right) \delta 7.40(\mathrm{~d}, J=8.1 \mathrm{~Hz}, 2 \mathrm{H}), 6.91(\mathrm{~d}, J=8.3 \mathrm{~Hz}$, 2H), 5.28 (qd, $J=15.3,6.3 \mathrm{~Hz}, 1 \mathrm{H}$ ), 5.14 (ddd, $J=15.1,9.7,1.1 \mathrm{~Hz}, 1 \mathrm{H}$ ), 3.82 (s, 3H), 3.28 (ddd, $J=$ 12.2, 8.0, $4.4 \mathrm{~Hz}, 1 \mathrm{H}), 3.12$ (td, $J=12.0,7.9 \mathrm{~Hz}, 1 \mathrm{H}), 1.73-1.68$ (m, 2H), 1.66 (dd, $J=6.4,1.2 \mathrm{~Hz}$, 3H), 1.48 (dddd, $J=13.5,12.0,7.4,4.5 \mathrm{~Hz}, 1 \mathrm{H}), 0.25$ (s, 3H), 0.24 (s, 3H).

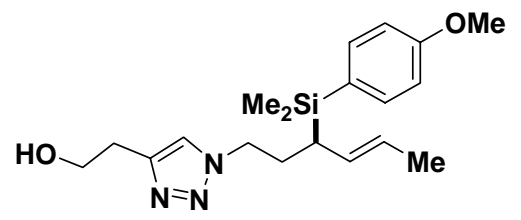

(R,E)-2-(1-(3-((4-methoxyphenyl)dimethylsilyl)hex-4-enyl)-1H-1,2,3-triazol-4-yl)ethanol (R-4). The procedure and characterization details are provided for the synthesis of $(R)$-triazole crotylsilane 4 from the $(R)$-crotylsilane azide. The same procedure was followed using the $(S)$-crotylsilane azide to afford the (S)-triazole crotylsilane 4. A variation of the same procedure is also employed for the 
solution-phase reactions with the TIPS-protected alkynol substrate. To a mixture of macrobead-bound alkyne (1.0 equiv, obtained by loading 3-butyn-1-ol) in $\mathrm{CH}_{2} \mathrm{Cl}_{2}$ and DIPEA (a 1:1 ratio), the crotylsilane azide (4.0 equiv) was added. Copper (I) iodide (2.0 equiv) was added and the cream slurry was stirred or agitated overnight on an IKA orbital shaker. Then the solution was drained and the resin was washed with the following protocol: THF ( 2 x $15 \mathrm{~min}$ ), $0.2 \mathrm{M}$ sodium diethyldithio carbamate trihydrate (DETC) in THF/ $\mathrm{H}_{2} \mathrm{O}$ (3:1 ratio, approximately $6 \times 15 \mathrm{~min}$ until the solution is colorless), $\mathrm{THF} / \mathrm{H}_{2} \mathrm{O}$ (3:1 ratio, 2 x $15 \mathrm{~min}$ ), THF (3 x $15 \mathrm{~min}$ ), $\mathrm{MeCN}$ (3 x $15 \mathrm{~min}$ ), and $\mathrm{CH}_{2} \mathrm{Cl}_{2}$ (3 x $15 \mathrm{~min}$ ). The beads were dried under a gradual vacuum (house vacuum) for $1 \mathrm{~h}$, and then dried under high vacuum for 12-24 h. Conversion was checked using on-bead analysis with magic angle spinning (MAS) ${ }^{1} \mathrm{H}$ NMR spectroscopy, or by HF/pyridine cleavage followed by solution analysis with LCMS or ${ }^{1} \mathrm{H}$ NMR spectroscopy, both of which indicated $>90 \%$ conversion. Performing the HF/py cleavage procedure for a single $\mathrm{x}$-Kan $(0.030 \mathrm{~g}, 0.033 \mathrm{mmol}$ of resin) afforded the product as a colorless oil (10.0 mg, 84\% average yield over three steps from loading of 3-butyn-1-ol): ${ }^{1} \mathrm{H}$ NMR (600 MHz, $\left.\mathrm{CDCl}_{3}\right) \delta 7.34(\mathrm{dd}, J=8.5,0.6 \mathrm{~Hz}, 2 \mathrm{H}), 7.23(\mathrm{~s}, 1 \mathrm{H}), 6.89$ (dd, $\left.J=8.6,0.7 \mathrm{~Hz}, 2 \mathrm{H}\right), 5.31$ (qd, $J=$ 12.5, $6.3 \mathrm{~Hz}, 1 \mathrm{H}), 5.20$ (dd, $J=15.3,9.4 \mathrm{~Hz}, 1 \mathrm{H}), 4.32$ (ddd, $J=13.3,8.6,4.5 \mathrm{~Hz}, 1 \mathrm{H}), 4.15$ (td, $J=$ 13.7, $8.1 \mathrm{~Hz}, 1 \mathrm{H}), 3.93$ (t, $J=5.8 \mathrm{~Hz}, 2 \mathrm{H}), 3.81$ (s, 3H), 2.92 (t, $J=5.8 \mathrm{~Hz}, 2 \mathrm{H}), 1.99$ (dtd, $J=13.8$, 8.1, $2.4 \mathrm{~Hz}, 1 \mathrm{H}$ ), 1.76 (ddt, $J=13.1,13.1,8.2,4.6 \mathrm{~Hz}, 1 \mathrm{H}), 1.69$ (d, $J=6.3 \mathrm{~Hz}, 3 \mathrm{H}$ ), 1.55 (ddd, $J=$ 11.9, 9.6, $2.0 \mathrm{~Hz}, 1 \mathrm{H}), 0.23$ (s, 3H), 0.21 (s, 3H); ${ }^{13} \mathrm{C} \mathrm{NMR}\left(100 \mathrm{MHz}, \mathrm{CDCl}_{3}\right) \delta 160.4,145.1,135.4$, 129.9, 127.5, 125.1, 121.4, 113.5, 61.6, 54.9, 49.7, 30.0, 29.8, 28.5, 18.1, -4.2, -5.3; ${ }^{29} \mathrm{Si}$ NMR (59 MHz, $\mathrm{CDCl}_{3}$ ) $\delta-3.0$; IR 3366, 3013, 2952, 2934, 1591, 1243, $809 \mathrm{~cm}^{-1}$; HRMS (TOF MS ES ${ }^{+}$) m/z calcd for $\mathrm{C}_{19} \mathrm{H}_{30} \mathrm{~N}_{3} \mathrm{O}_{2} \mathrm{Si}(\mathrm{M}+\mathrm{H})^{+} 360.2107$, found 360.2097.
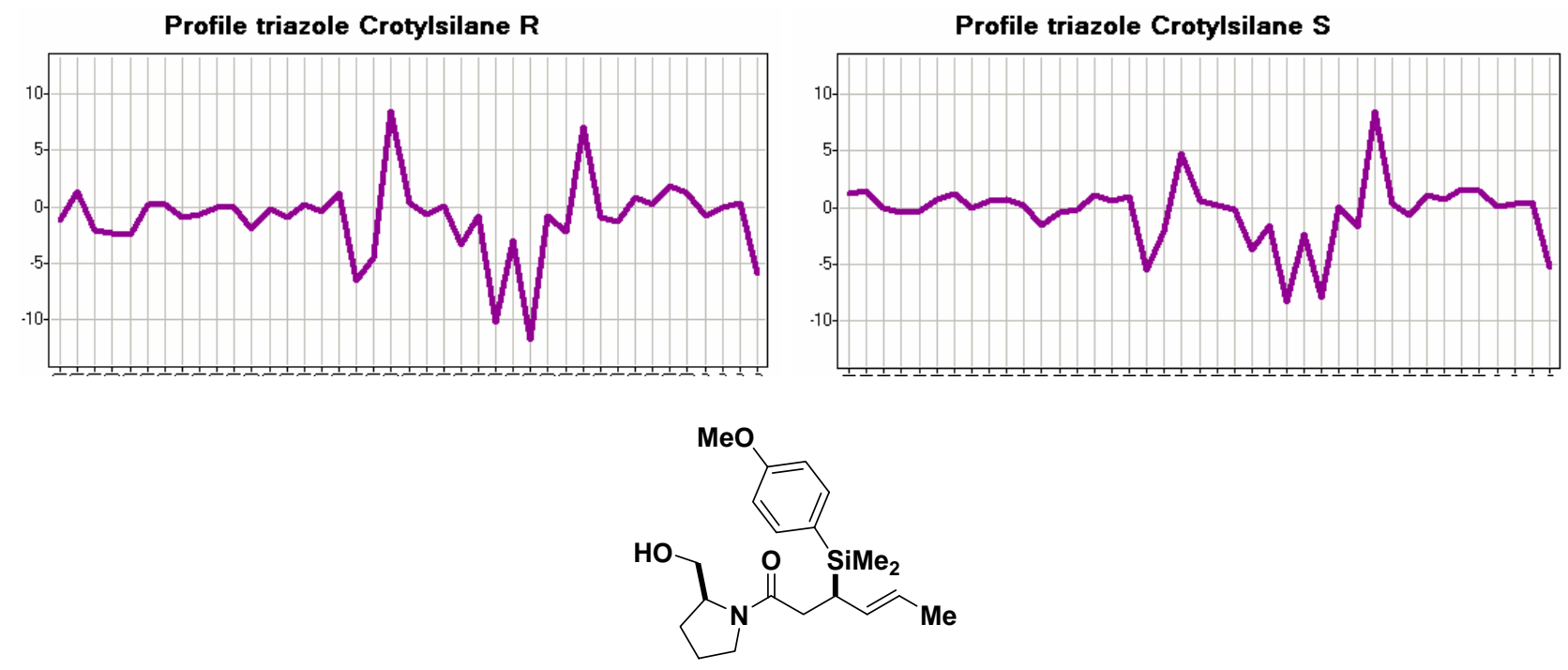

(R,E)-1-((S)-2-(hydroxymethyl)pyrrolidin-1-yl)-3-((4-methoxyphenyl)dimethylsilyl)hex-4-en-1-

one $(\boldsymbol{R}-\mathbf{2})$. The procedure and characterization details are provided for the synthesis of $(R)$-amido crotylsilane 2 from the $(R)$-crotylsilane acid. The same procedure was followed using the $(S)$ crotylsilane acid to afford the (S)-amido crotylsilane 2. A solution of $(R)$-crotylsilane acid (2.5 equiv in $\mathrm{CH}_{2} \mathrm{Cl}_{2}$ ) was mixed with PyBroP (2.4 equiv) and DIPEA (6.0 equiv). Once dissolved, the solution was transferred by syringe to a vial containing macrobead-bound $(S)$-prolinol (1.0 equiv, obtained by loading FMOC-protected (S)-prolinol, followed by deprotection with a solution of $20 \%$ piperidine in DMF) that had been pre-swollen in $\mathrm{CH}_{2} \mathrm{Cl}_{2}$ and then drained. The reaction mixture was agitated overnight on an IKA orbital shaker. Then the solution was drained and the resin was washed with the following protocol: $\mathrm{CH}_{2} \mathrm{Cl}_{2}$ ( 3 x $15 \mathrm{~min}$ ), THF ( 3 x $15 \mathrm{~min}$ ), $\mathrm{MeCN}$ ( 3 x $15 \mathrm{~min}$ ), and $\mathrm{CH}_{2} \mathrm{Cl}_{2}$ ( 3 x 15 
min). The beads were dried under a gradual vacuum (house vacuum) for $1 \mathrm{~h}$, and then dried under high vacuum for 12-24 h. Conversion was checked using on-bead analysis with magic angle spinning (MAS) ${ }^{1} \mathrm{H}$ NMR spectroscopy and by HF/pyridine cleavage followed by solution analysis with LCMS or ${ }^{1} \mathrm{H}$ NMR spectroscopy, both of which indicated $>90 \%$ conversion. Performing the HF/py cleavage procedure for a single $\mathrm{x}$-Kan $(0.030 \mathrm{~g}, 0.033 \mathrm{mmol}$ of resin) afforded the product as a colorless oil (8.3 mg, 70\% average yield over 4 steps from loading of FMOC-protected (S)-prolinol): ${ }^{1} \mathrm{H}$ NMR (600 $\left.\mathrm{MHz}, \mathrm{CDCl}_{3}\right) \delta 7.41$ (d, $\left.J=8.5 \mathrm{~Hz}, 2 \mathrm{H}\right), 6.91$ (d, $\left.J=8.5 \mathrm{~Hz}, 2 \mathrm{H}\right), 5.32$ (dd, $J=15.8,8.5 \mathrm{~Hz}, 1 \mathrm{H}$ ), 5.25 (dq, $J=15.2,5.9$ Hz, 1H), 5.07 (bs, 1H), 4.16 (dq, $J=8.3,2.2$ Hz, 1H), 3.82 (s, 3H), 3.62 (d, $J=$ $11.1 \mathrm{~Hz}, 1 \mathrm{H}$ ), 3.47 (dd, $J=11.2,8.4 \mathrm{~Hz}, 1 \mathrm{H}$ ), 3.40 (ddd, $J=10.1,7.1,6.0 \mathrm{~Hz}, 1 \mathrm{H}$ ), 3.31 (td, $J=10.1$, $7.0 \mathrm{~Hz}, 1 \mathrm{H}), 2.32-2.22$ (m, 3H), 1.98 (dt, $J=14.3,7.0 \mathrm{~Hz}, 1 \mathrm{H}), 1.86(\mathrm{dt}, J=12.8,6.4 \mathrm{~Hz}, 1 \mathrm{H}), 1.76$ $(\mathrm{dt}, J=14.4,7.2 \mathrm{~Hz}, 1 \mathrm{H}), 1.64$ (d, $J=5.8 \mathrm{~Hz}, 3 \mathrm{H}), 1.51(\mathrm{dt}, J=13.3,6.9 \mathrm{~Hz}, 1 \mathrm{H}), 0.27(\mathrm{~s}, 6 \mathrm{H}) ;{ }^{13} \mathrm{C}$ NMR $\left(100 \mathrm{MHz}, \mathrm{CDCl}_{3}\right) \delta 174.2,160.4,135.5,130.3,127.8,123.7,113.5,67.6,61.0,55.0,48.0$, 35.0, 28.6, 28.2, 24.5, 18.2, -4.0, -4.9; IR 3387, 3017, 2952, 2922, 2874, 1617, 1595, 1435, $822 \mathrm{~cm}^{-1}$; HRMS (TOF MS ES ${ }^{+}$) m/z calcd for $\mathrm{C}_{20} \mathrm{H}_{32} \mathrm{NO}_{3} \mathrm{Si}(\mathrm{M}+\mathrm{H})^{+}$362.2151, found 362.2137.
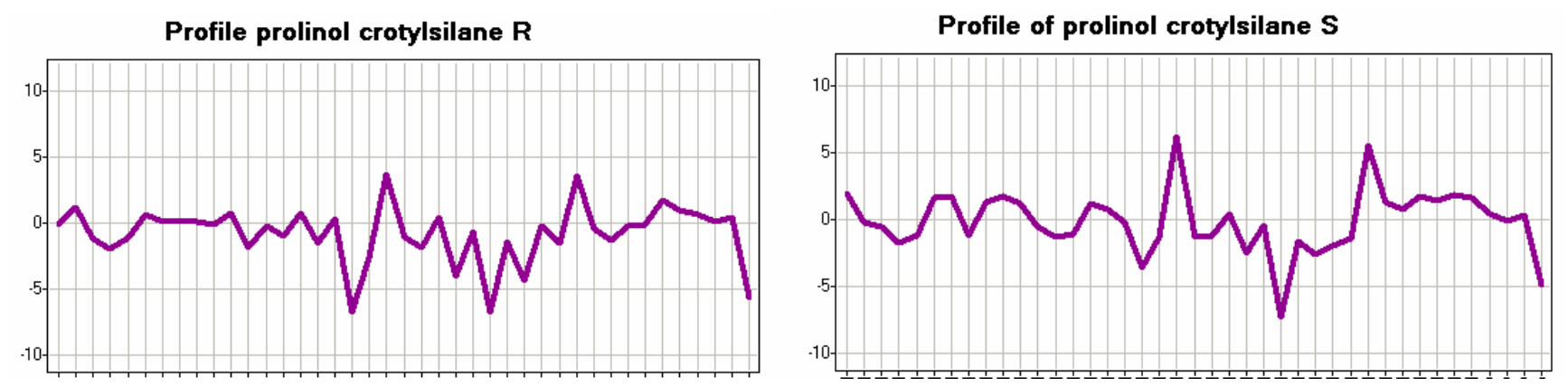

Representative spirocyclic products derived from annulation with ester crotylsilane 1:

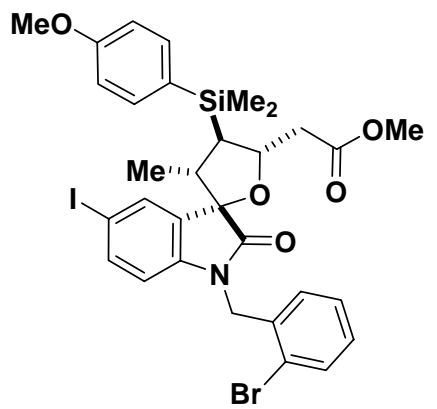

Spirocyclic annulation product ester-61. Representative procedure for solution phase Tin(IV) chloride-mediated annulations with crotylsilanes. A racemic solution of (E)-methyl 3-(dimethyl(4methoxyphenyl)silyl)hex-4-enoate (1) (1.80 g, $6.16 \mathrm{mmol}$ ) was dissolved in $23 \mathrm{~mL}$ of $\mathrm{CH}_{2} \mathrm{Cl}_{2}$ in a 100 $\mathrm{mL}$ round bottom flask equipped with a stirbar and a rubber septum under positive argon pressure. $N$ (2-bromobenzyl)-5-iodoisatin (5l) (4.50 g, $10.18 \mathrm{mmol})$ was added and the reaction mixture was cooled to $-78{ }^{\circ} \mathrm{C}$. A solution of tin(IV) chloride $\left(12.39 \mathrm{~mL}, 1.0 \mathrm{M}\right.$ in $\mathrm{CH}_{2} \mathrm{Cl}_{2}$ ) was subsequently added to the reaction at $-78{ }^{\circ} \mathrm{C}$, and then the reaction was kept at $-20{ }^{\circ} \mathrm{C}$ for $48 \mathrm{~h}$. The reaction mixture was quenched by the addition of $\mathrm{Et}_{3} \mathrm{~N}(10 \mathrm{~mL})$ and $\mathrm{H}_{2} \mathrm{O}(10 \mathrm{~mL})$, and then allowed to warm to $23^{\circ} \mathrm{C}$. Then the reaction mixture was partitioned between EtOAc $(20 \mathrm{~mL})$ and $\mathrm{H}_{2} \mathrm{O}(20 \mathrm{~mL})$ and extracted with EtOAc $(3 \times 20 \mathrm{~mL})$. The combined organic layers were dried $\left(\mathrm{Na}_{2} \mathrm{SO}_{4}\right)$ and concentrated in vacuo. The resulting orange solid was purified by flash chromatography (0:100 - 35:65 EtOAc/hexanes) to yield the product as a white solid (3.36 g, 74\%). The product was crystallized from 
EtOAc/hexanes $/ \mathrm{CH}_{2} \mathrm{Cl}_{2}$ to afford crystals suitable for X-ray crystallographic analysis. ${ }^{1} \mathrm{H}$ NMR (600 $\left.\mathrm{MHz}_{2} \mathrm{CDCl}_{3}\right) \delta 7.57(\mathrm{~d}, J=8.0 \mathrm{~Hz}, 1 \mathrm{H}), 7.50-7.46(\mathrm{~m}, 4 \mathrm{H}), 7.19(\mathrm{t}, J=7.5,7.5 \mathrm{~Hz}, 1 \mathrm{H}), 7.12(\mathrm{t}, J=$ 7.6, $7.6 \mathrm{~Hz}, 1 \mathrm{H}), 7.01$ (d, $J=7.7 \mathrm{~Hz}, 1 \mathrm{H}), 6.95$ (d, $J=8.5 \mathrm{~Hz}, 2 \mathrm{H}), 6.39$ (d, $J=8.2 \mathrm{~Hz}, 1 \mathrm{H}), 5.02(\mathrm{~d}, J$ $=16.6 \mathrm{~Hz}, 1 \mathrm{H}), 4.79(\mathrm{~d}, J=16.6 \mathrm{~Hz}, 1 \mathrm{H}), 4.72$ (ddd, $J=11.3,6.8,3.0 \mathrm{~Hz}, 1 \mathrm{H}), 3.82(\mathrm{~s}, 3 \mathrm{H}), 3.65$ (s, 3H), 2.81 (qd, $J=13.6,6.8,6.8,6.8 \mathrm{~Hz}, 1 \mathrm{H}), 2.48$ (dd, $J=15.2,3.0 \mathrm{~Hz}, 1 \mathrm{H}), 2.22$ (dd, $J=15.2,6.8$ $\mathrm{Hz}, 1 \mathrm{H}), 1.68$ (t, $J=12.1,12.1 \mathrm{~Hz}, 1 \mathrm{H}), 0.67$ (d, $J=6.9 \mathrm{~Hz}, 3 \mathrm{H}), 0.46(\mathrm{~s}, 6 \mathrm{H}) ;{ }^{13} \mathrm{C} \mathrm{NMR}(100 \mathrm{MHz}$, $\left.\mathrm{CDCl}_{3}\right) \delta 177.7,171.0,160.8,142.1,138.1,135.2$, 133.8, 133.7, 132.9, 131.4, 129.1, 127.8, 127.1, 122.7, 113.9, 111.3, 86.2, 85.6, 80.9, 77.3, 76.9, 76.6, 55.0, 51.7, 46.9, 43.9, 39.5, 38.8, 15.3, -2.9, 4.1; HRMS (EI) $\mathrm{m} / \mathrm{z}$ calcd for $\mathrm{C}_{31} \mathrm{H}_{37} \mathrm{BrIN}_{2} \mathrm{O}_{5} \mathrm{Si}\left(\mathrm{M}+\mathrm{NH}_{4}\right)^{+} 751.0700$, found 751.0687 .

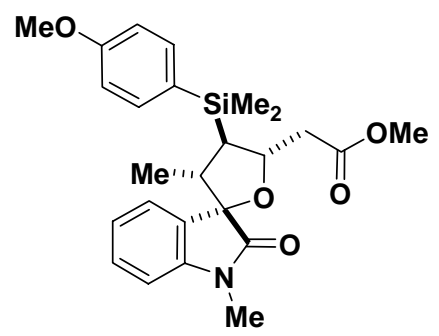

Spirocyclic annulation product ester-6c. The representative procedure for tin(IV) chloride mediated annulations was followed using $1.46 \mathrm{~g}(4.99 \mathrm{mmol})$ of racemic (E)-methyl 3-(dimethyl(4methoxyphenyl)silyl)hex-4-enoate (1), $N$-methylisatin (5c) (2.41g, $14.94 \mathrm{mmol}$ ), and $9.96 \mathrm{~mL}$ of tin(IV) chloride $\left(9.96 \mathrm{mmol}, 1.0 \mathrm{M}\right.$ in $\mathrm{CH}_{2} \mathrm{Cl}_{2}$ ). The resulting orange solid was purified by flash chromatography to yield the product as a colorless oil $(2.03 \mathrm{~g}, 87 \%):{ }^{1} \mathrm{H}$ NMR $\left(500 \mathrm{MHz}, \mathrm{CDCl}_{3}\right) \delta$ 7.56-7.54 (m, 2H), 7.39-7.37 (m, 2H), $7.26(\mathrm{td}, J=7.8,1.5,1 \mathrm{H}), 7.20(\mathrm{~d}, J=7.3,1 \mathrm{H}), 7.04(\mathrm{t}, J=6.8$, $1 \mathrm{H}), 6.76$ (d, $J=7.8,1 \mathrm{H}), 4.75$ (ddd, $J=11.2,7.3,2.9,1 \mathrm{H}), 3.58$ (s, 3H), 3.14 (s, 3H), 2.74 (qd, $J=$ 12.7, 6.8, 1H), 2.41 (dd, $J=15.1,2.9,1 \mathrm{H}), 2.24$ (dd, $J=15.1,7.4,1 \mathrm{H}), 1.67$ (t, $J=12.3,1 \mathrm{H}), 0.56$ (d, $J=6.8,3 \mathrm{H}), 0.465$ (s, 3H), 0.459 (s, 3H); $\left.{ }^{13} \mathrm{C} \mathrm{NMR} \mathrm{(100} \mathrm{MHz,} \mathrm{CDCl}_{3}\right) \delta 177.9,177.9,143.5,136.8$, 133.7, 129.6, 129.3, 129.0, 128.1, 124.9, 122.5, 108.2, 86.6, 80.3, 51.6, 46.4, 40.1, 38.8, 26.3, 15.0, 3.1, -4.1; ${ }^{29} \mathrm{Si}$ NMR (59 MHz, $\left.\mathrm{CDCl}_{3}\right) \delta-4.7$; HRMS (EI) $\mathrm{m} / \mathrm{z}$ calcd for $\mathrm{C}_{25} \mathrm{H}_{35} \mathrm{~N}_{2} \mathrm{O}_{5} \mathrm{Si}\left(\mathrm{M}+\mathrm{NH}_{4}\right)^{+}$ 471.2315, found 471.2310.

\section{Representative spirocyclic products derived from annulation with crotylsilane 3:}

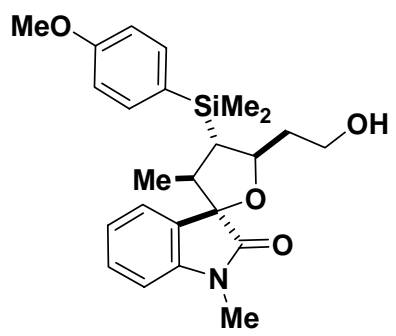

Spirocyclic annulation product hydroxyl-6c. Method A procedure for crotylsilane annulations with TIPS silyl ether, followed by Si-O deprotection. Racemic (E)-1-(dimethyl(1(triisopropylsilyloxy)hex-4-en-3-yl)silyl)-4-methoxybenzene $(0.600 \mathrm{~g}, 1.43 \mathrm{mmol}$ ) was dissolved in 6 $\mathrm{mL}$ of $\mathrm{CH}_{2} \mathrm{Cl}_{2}$ in a $100 \mathrm{~mL}$ round bottom flask under positive argon pressure. $N$-methylisatin (5c) (0.607 g, $3.77 \mathrm{mmol})$ and a solution of DTBMP (4.74 mL, $2.37 \mathrm{mmol}, 0.5 \mathrm{M}$ in $\mathrm{CH}_{2} \mathrm{Cl}_{2}$ ) was added and the reaction mixture was cooled to $-78{ }^{\circ} \mathrm{C}$. After $10 \mathrm{~min}$, a solution of tin(IV) chloride $(4.74 \mathrm{~mL}$, $4.74 \mathrm{mmol}, 1.0 \mathrm{M}$ in $\mathrm{CH}_{2} \mathrm{Cl}_{2}$ ) was added to the reaction at $-78{ }^{\circ} \mathrm{C}$ and the reaction was maintained at - 
$20{ }^{\circ} \mathrm{C}$ for $48 \mathrm{~h}$. The reaction mixture was quenched by the addition of $\mathrm{Et}_{3} \mathrm{~N}(10 \mathrm{~mL})$ and $\mathrm{H}_{2} \mathrm{O}(10 \mathrm{~mL})$, and then allowed to warm to $23^{\circ} \mathrm{C}$. The reaction mixture was partitioned between EtOAc $(20 \mathrm{~mL})$ and $\mathrm{H}_{2} \mathrm{O}(20 \mathrm{~mL})$ and then extracted with EtOAc $(3 \times 20 \mathrm{~mL})$. The combined organic layers were dried $\left(\mathrm{Na}_{2} \mathrm{SO}_{4}\right)$ and concentrated in vacuo. The resulting silyl ether annulation product was purified by flash chromatography (10:90 - 20:80 EtOAc/hexanes) to yield the product as a colorless oil (0.77 g, $93 \%)$ : ${ }^{1} \mathrm{H}$ NMR $\left(600 \mathrm{MHz}, \mathrm{CDCl}_{3}\right) \delta \mathrm{ppm} 7.48(\mathrm{~d}, J=8.6 \mathrm{~Hz}, 2 \mathrm{H}), 7.28(\mathrm{dd}, J=15.7,7.8 \mathrm{~Hz}, 2 \mathrm{H}), 7.06(\mathrm{t}, J$ $=7.5 \mathrm{~Hz}, 1 \mathrm{H}), 6.94(\mathrm{~d}, J=8.6 \mathrm{~Hz}, 2 \mathrm{H}), 6.80(\mathrm{~d}, J=7.7 \mathrm{~Hz}, 1 \mathrm{H}), 4.52$ (ddd, $J=10.7,9.3,1.4 \mathrm{~Hz}$, 1H), 3.85 (dd, $J=9.8,4.9 \mathrm{~Hz}, 1 \mathrm{H}), 3.83$ (s, 3H), 3.73 (td, $J=9.8,7.4,7.4 \mathrm{~Hz}, 1 \mathrm{H}), 3.17$ (s, 3H), 2.70 (qd, $J=13.6,6.8 \mathrm{~Hz}, 1 \mathrm{H}), 1.85$ (td, $J=15.4,7.9,7.9 \mathrm{~Hz}, 1 \mathrm{H}), 1.74$ (dtd, $J=9.1,7.7,7.6,4.9 \mathrm{~Hz}, 1 \mathrm{H}$ ), 1.49 (dd, $J=12.5,11.4 \mathrm{~Hz}, 1 \mathrm{H}), 1.05$ (d, $J=3.7 \mathrm{~Hz}, 18 \mathrm{H}+\mathrm{m}, 3 \mathrm{H}$, buried), 0.50 (d, $J=6.8 \mathrm{~Hz}, 3 \mathrm{H}$ ), 0.445 (s, 3H), 0.435 (s, 3H); ${ }^{13} \mathrm{C}$ NMR $\left(100 \mathrm{MHz}, \mathrm{CDCl}_{3}\right) \delta 178.1,160.5,143.3,135.1,129.5,128.9$, 127.8, 124.8, 122.3, 113.7, 108.0, 86.7, 81.4, 77.3, 77.0, 76.6, 60.9, 54.8, 46.5, 40.3, 40.2, 26.2, 17.9, 14.7, 11.8, $-3.0,-3.3$.

To an $8 \mathrm{~mL}$ plastic vial was added the TIPS-protected spiroxindole (0.150 g. $0.258 \mathrm{mmol})$. The reaction mixture was then treated with a pre-made solution of 5\% HF/py in THF (2.0 mL) for $2 \mathrm{~h}$ followed by quenching with TMSOEt $(4.0 \mathrm{~mL})$ for $30 \mathrm{~min}$. The reaction mixture was concentrated in vacuo, dissolved (3:1 hexanes/EtOAc) and purified by flash chromatography (20:80 - 40:60 EtOAc/hexanes) to yield the product as a colorless oil (0.093 g, $85 \%)$. See characterization and NMR spectral data listed for Method B.

Method B procedure for annulations with solid supported-crotylsilane, followed by Si-O cleavage. The procedure and characterization details are provided for the synthesis of the $(R)$ spirocycle from the crotylsilane $(R)-3 \mathbf{b}$. The same procedure was followed using crotylsilane $(S)-3 \mathbf{b}$ to afford the $(S)$-spirocycle. To a $4 \mathrm{ml}$ vial was added $0.030 \mathrm{~g}(0.033 \mathrm{mmol})$ of macrobead-supported crotylsilane $(R)-3 \mathbf{b}$ and $N$-methylisatin $5 \mathbf{c}(0.022 \mathrm{~g}, 0.136 \mathrm{mmol})$. Then $0.5 \mathrm{~mL}$ of $\mathrm{CH}_{2} \mathrm{Cl}_{2}$ was added and the beads were allowed to swell. After $30 \mathrm{~min}$, the reaction mixture was cooled to $-78^{\circ} \mathrm{C}$ and $0.100 \mathrm{~mL}$ of DTBMP solution $\left(0.05 \mathrm{mmol}, 0.5 \mathrm{M}\right.$ in $\left.\mathrm{CH}_{2} \mathrm{Cl}_{2}\right)$ was added. After $10 \mathrm{~min}, 0.100 \mathrm{~mL}$ of tin(IV) chloride $\left(0.10 \mathrm{mmol}, 1.0 \mathrm{M}\right.$ in $\left.\mathrm{CH}_{2} \mathrm{Cl}_{2}\right)$ was added at $-78{ }^{\circ} \mathrm{C}$, and the reaction was maintained at $-20^{\circ} \mathrm{C}$ for $72 \mathrm{~h}$. The reaction mixture was quenched with $0.3 \mathrm{~mL}$ of $\mathrm{Et}_{3} \mathrm{~N}$, and the beads were then washed with $\mathrm{CH}_{2} \mathrm{Cl}_{2}(3 \times 10 \mathrm{~min})$, THF $(3 \times 10 \mathrm{~min})$, acetonitrile $(3 \times 10 \mathrm{~min}), \mathrm{CH}_{2} \mathrm{Cl}_{2}(3 \times 10 \mathrm{~min})$ and dried in vacuo. To obtain the crude compound for analysis and characterization, the macrobeads were treated with $0.250 \mathrm{~mL}$ of a $5 \%$ solution of HF/py in THF for 3h followed by quenching with 0.50 $\mathrm{mL}$ of TMSOEt and mixing/shaking for $30 \mathrm{~min}$. The beads were extracted with THF $(3 \times 1.0 \mathrm{~mL})$ and the combined organic layers were concentrated in vacuo, analyzed by LCMS (or SFC/MS), and then purified by flash chromatography $\left(\mathrm{CH}_{2} \mathrm{Cl}_{2} / \mathrm{EtOAc}\right)$ to yield the product as a colorless oil (9.6 mg, 68\% over three steps from loading of crotylsilane 3a): ${ }^{1} \mathrm{H}$ NMR $\left(600 \mathrm{MHz}, \mathrm{CDCl}_{3}\right) \delta 7.43(\mathrm{~d}, J=8.2 \mathrm{~Hz}$, 2H), 7.27 (t, $J=7.8 \mathrm{~Hz}, 1 \mathrm{H}), 7.23$ (d, $J=7.3 \mathrm{~Hz}, 1 \mathrm{H}), 7.04$ (t, $J=7.5 \mathrm{~Hz}, 1 \mathrm{H}), 6.92(\mathrm{~d}, J=8.1 \mathrm{~Hz}$, 2H), 6.79 (d, $J=7.7 \mathrm{~Hz}, 1 \mathrm{H}$ ), 4.53 (ddd, $J=11.2,9.0,2.4 \mathrm{~Hz}, 1 \mathrm{H}), 3.81$ (s, 3H), 3.75-3.66 (m, 1H), 3.66-3.61 (m, 1H), 3.16 (s, 3H), 2.68 (qd, $J=13.4,6.8$ Hz, 1H), 2.45 (bs, 1H), 1.73-1.56 (m, $2 \mathrm{H}), 1.45$ $(\mathrm{t}, J=11.9 \mathrm{~Hz}, 1 \mathrm{H}), 0.52(\mathrm{~d}, J=6.8 \mathrm{~Hz}, 3 \mathrm{H}), 0.404(\mathrm{~s}, 3 \mathrm{H}), 0.401(\mathrm{~s}, 3 \mathrm{H}) ;{ }^{13} \mathrm{C}$ NMR $(100 \mathrm{MHz}$, $\left.\mathrm{CDCl}_{3}\right) \delta 177.9,160.7,143.3,135.1,129.2,128.9,127.6,124.8,122.6,113.8,108.2,86.7,84.7,61.3$, 54.9, 46.2, 40.7, 38.5, 26.3, 14.9, -3.1, -3.5; ${ }^{29} \mathrm{Si}$ NMR (59 MHz, $\mathrm{CDCl}_{3}$ ) $\delta$-4.5; IR (method) 3441, 2951, 2874, 1710, 1274, 1247, $1020 \mathrm{~cm}^{-1}$; HRMS (TOF MS ES ${ }^{+}$) m/z calcd for $\mathrm{C}_{24} \mathrm{H}_{35} \mathrm{~N}_{2} \mathrm{O}_{4} \mathrm{Si}(\mathrm{M}+$ $\left.\mathrm{NH}_{4}\right)^{+}$443.2366, found 443.2362. 

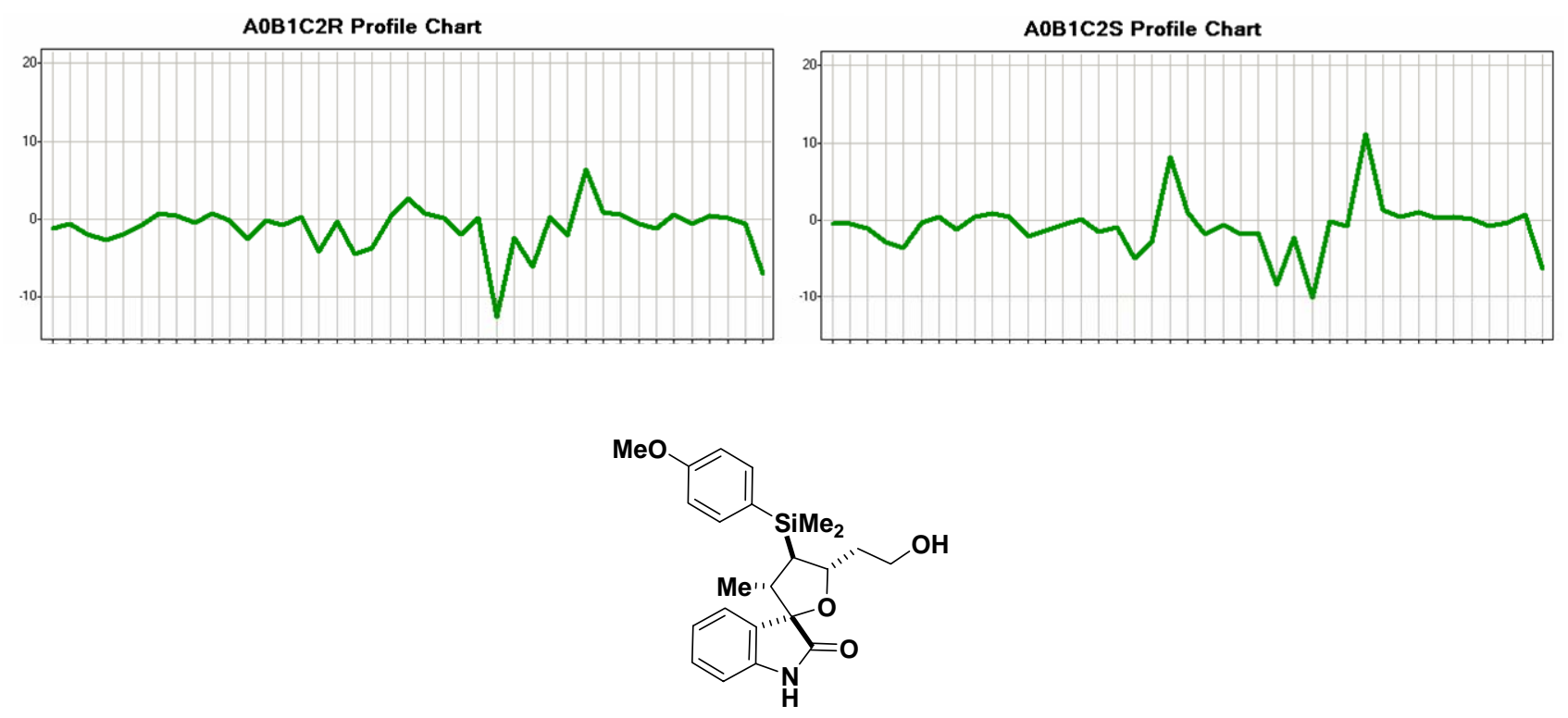

Spirocyclic annulation product hydroxyl-6d. The Method B procedure for the Lewis acid-mediated macrobead annulation and Si-O cleavage was followed using $0.60 \mathrm{~g}$ of macrobead-supported crotylsilane $(R)$-3b $(0.066 \mathrm{mmol}$, in X-kans), isatin (0.040 g, $0.272 \mathrm{mmol}), 0.132 \mathrm{~mL}$ of DTBMP

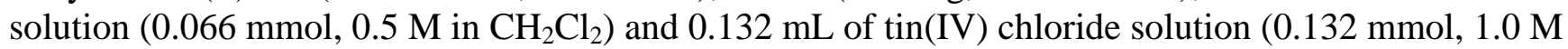
in $\mathrm{CH}_{2} \mathrm{Cl}_{2}$ ) to yield the product as an colorless oil $(15.1 \mathrm{mg}, 56 \%$ over 3 steps from loading of crotylsilane 3a): ${ }^{1} \mathrm{H}$ NMR (500 MHz, $\left.\mathrm{CDCl}_{3}\right) \delta 7.54(\mathrm{bs}, 1 \mathrm{H}), 7.43(\mathrm{~d}, J=8.6 \mathrm{~Hz}, 2 \mathrm{H}), 7.21(\mathrm{t}, J=7.6$ $\mathrm{Hz}, 2 \mathrm{H}), 7.03$ (dt, $J=7.6,0.8 \mathrm{~Hz}, 1 \mathrm{H}), 6.93(\mathrm{~d}, J=8.6 \mathrm{~Hz}, 2 \mathrm{H}), 6.82(\mathrm{dd}, J=8.2,0.7 \mathrm{~Hz}, 1 \mathrm{H}), 4.52$ (ddd, $J=11.4,8.8,2.9 \mathrm{~Hz}, 1 \mathrm{H}$ ), $3.82(\mathrm{~s}, 3 \mathrm{H}), 3.71(\mathrm{~m}, 1 \mathrm{H}), 3.66(\mathrm{~m}, 1 \mathrm{H}), 2.67$ (qd, $J=13.6,6.8 \mathrm{~Hz}$, 1H), 2.40 (bs, 1H), 1.72-1.61 (m, 2H), 1.45 (dd, $J=12.6,11.3 \mathrm{~Hz}, 1 \mathrm{H}), 0.58$ (d, $J=6.8 \mathrm{~Hz}, 3 \mathrm{H}$ ), 0.412 (s, 3H), 0.407 (s, 3H); ${ }^{13} \mathrm{C}$ NMR $\left(125 \mathrm{MHz}, \mathrm{CDCl}_{3}\right) \delta 180.1,160.7,140.3,135.1,129.4,129.3$, 127.6, 125.2, 122.6, 113.8, 110.2, 87.1, 84.9, 61.2, 55.0, 46.5, 40.5, 38.7, 14.7, -3.1, -3.5; LCMS (EI) $\mathrm{m} / \mathrm{z}$ calcd for $\mathrm{C}_{23} \mathrm{H}_{29} \mathrm{NO}_{4} \mathrm{Si}(\mathrm{M}+\mathrm{Na})^{+} 434.18$, found 434.10 .

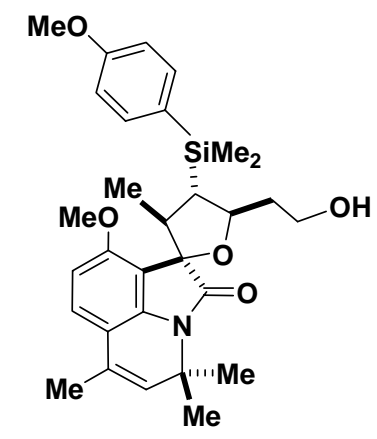

Spirocyclic annulation product hydroxyl-6a. The Method B procedure for the Lewis acid-mediated macrobead annulation and $\mathrm{Si}-\mathrm{O}$ cleavage was followed using $0.090 \mathrm{~g}$ of macrobead-supported crotylsilane (R)-3b (0.099, $3 \mathrm{X}$-kans), isatin $5 \mathbf{a}(0.045 \mathrm{~g}, 0.175 \mathrm{mmol})$, DTBMP (0.020g, $0.100 \mathrm{mmol})$ and $0.20 \mathrm{~mL}$ of tin(IV) chloride solution $\left(0.200 \mathrm{mmol}, 1.0 \mathrm{M}\right.$ in $\left.\mathrm{CH}_{2} \mathrm{Cl}_{2}\right)$ to yield the product as an colorless oil (0.033 g, $65 \%$ over 3 steps from crotylsilane 3a): ${ }^{1} \mathrm{H}$ NMR (500 MHz, $\left.\mathrm{CDCl}_{3}\right) \delta 7.44$ (d, $J$ $=8.6 \mathrm{~Hz}, 2 \mathrm{H}), 6.97(\mathrm{~d}, J=8.5 \mathrm{~Hz}, 1 \mathrm{H}), 6.94-6.91(\mathrm{~m}, 2 \mathrm{H}), 6.42(\mathrm{~d}, J=8.5 \mathrm{~Hz}, 1 \mathrm{H}), 5.07(\mathrm{~d}, J=1.4$ Hz, 1H), 4.49 (ddd, $J=11.1,7.1,3.6$ Hz, 1H), 3.84 (s, 3H), 3.82 (s, 3H), 3.69-3.63 (m, 2H), 2.72 (qd, 
$J=13.7,6.9 \mathrm{~Hz}, 1 \mathrm{H}), 2.62$ (bs, 1H), 1.96 (d, $J=1.3 \mathrm{~Hz}, 3 \mathrm{H}), 1.84$ (dd, $J=12.4,11.4 \mathrm{~Hz}, 1 \mathrm{H}), 1.71-$ 1.66 (m, 2H), 1.64 (s, 3H), 1.60 (s, 3H), 0.67 (d, $J=6.9 \mathrm{~Hz}, 3 \mathrm{H}), 0.39$ (s, 3H), 0.38 (s, 3H); ${ }^{13} \mathrm{C}$ NMR $\left(125 \mathrm{MHz} \mathrm{CDCl}_{3}\right) \delta 178.9,160.5,155.9,140.6,135.1,128.4,128.1,124.7,124.2,113.7,113.2,112.4$, 104.7, 88.4, 85.7, 61.1, 56.4, 55.1, 55.0, 45.9, 40.0, 36.6, 27.5, 27.3, 17.5, 14.8, -3.0, -3.5; LCMS (EI) $\mathrm{m} / \mathrm{z}$ calcd for $\mathrm{C}_{30} \mathrm{H}_{39} \mathrm{NO}_{5} \mathrm{Si}\left(\mathrm{M}+\mathrm{NH}_{4}\right)^{+}$539.29, found 539.29.
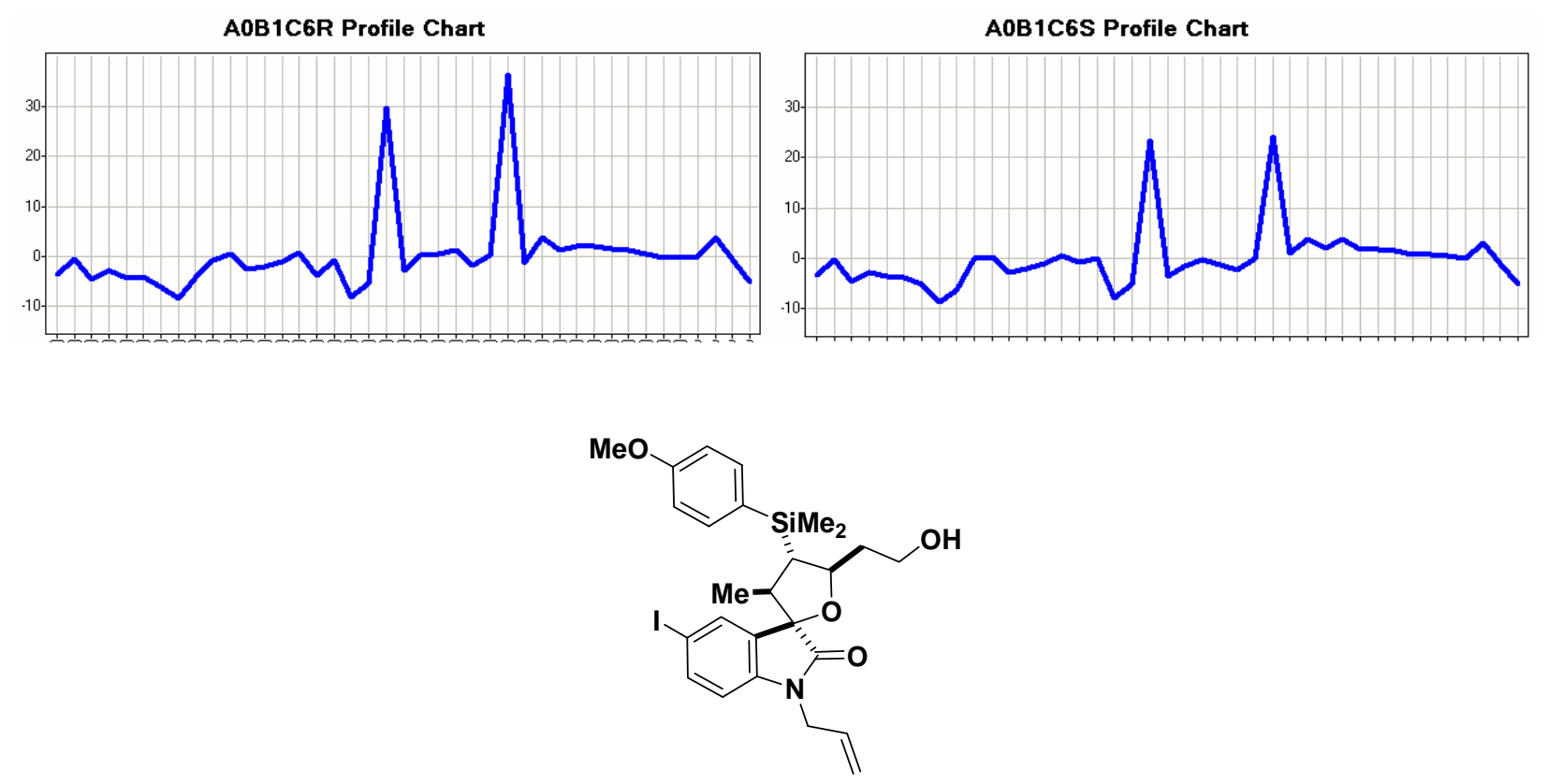

Spirocyclic annulation product hydroxyl-6f (7b). The method B procedure for the Lewis acidmediated macrobead annulation and Si-O cleavage was followed using $0.060 \mathrm{~g}$ of macrobeadsupported crotylsilane (S)-3b (0.066 mmol, 2 X-kans), $N$-allyl-5-iodoisatin $5 f$ (0.042 g, 0.132 mmol), $0.132 \mathrm{~mL}$ of DTBMP solution $\left(0.066 \mathrm{mmol}, 0.05 \mathrm{M}\right.$ in $\left.\mathrm{CH}_{2} \mathrm{Cl}_{2}\right)$ and $0.132 \mathrm{~mL}$ of tin(IV) chloride solution (0.132 mmol, $1.0 \mathrm{M}$ in $\left.\mathrm{CH}_{2} \mathrm{Cl}_{2}\right)$ to yield the product as a colorless oil $(0.027 \mathrm{~g}, 71 \%$ over 3 steps from crotylsilane 3a): ${ }^{1} \mathrm{H}$ NMR $\left(600 \mathrm{MHz}^{\mathrm{CDCl}} \mathrm{CDC}_{3}\right) \delta .56$ (dd, $\left.J=8.2,1.6 \mathrm{~Hz}, 1 \mathrm{H}\right), 7.46(\mathrm{~d}, J=$ $1.5 \mathrm{~Hz}, 1 \mathrm{H}), 7.44$ (d, $J=8.5 \mathrm{~Hz}, 2 \mathrm{H}), 6.94$ (d, $J=8.5 \mathrm{~Hz}, 2 \mathrm{H}), 6.57$ (d, $J=8.2 \mathrm{~Hz}, 1 \mathrm{H}), 5.77$ (tdd, $J=$ 15.7, 10.4, 5.3, $5.3 \mathrm{~Hz}, 1 \mathrm{H}$ ), 5.19 (dd, $J=17.2,14.2 \mathrm{~Hz}, 2 \mathrm{H}$ ), 4.50 (ddd, $J=11.3,9.2,2.3 \mathrm{~Hz}, 1 \mathrm{H}$ ), 4.39 (dd, $J=16.4,5.2 \mathrm{~Hz}, 1 \mathrm{H}), 4.13$ (dd, $J=16.4,5.4 \mathrm{~Hz}, 1 \mathrm{H}), 3.82$ (s, $1 \mathrm{H}), 3.69$ (ddd, $J=11.7,7.8$, $4.2 \mathrm{~Hz}, 1 \mathrm{H}$ ), 3.64 (m, 1H), 2.68 (qd, $J=13.6,6.8,6.8,6.8 \mathrm{~Hz}, 1 \mathrm{H}), 2.21$ (s, 1H), 1.68-1.57 (m, 2H), 1.37 (dd, $J=12.4,11.6 \mathrm{~Hz}, 1 \mathrm{H}), 0.56$ (d, $J=6.9 \mathrm{~Hz}, 3 \mathrm{H}), 0.422$ (d, $J=3.9 \mathrm{~Hz}, 3 \mathrm{H}), 0.415$ (d, $J=3.9$ $\mathrm{Hz}, 3 \mathrm{H}) ;{ }^{13} \mathrm{C}$ NMR $\left(100 \mathrm{MHz}, \mathrm{CDCl}_{3}\right) \delta 177.1,160.8,142.3,138.0,135.2,133.5,131.5,130.8,127.3$, 117.8, 113.8, 111.3, 86.4, 85.3, 85.0, 61.3, 55.0, 46.6, 42.4, 40.9, 38.6, 15.0, -3.0, -3.6; HRMS (TOF MS ES $\left.{ }^{+}\right) \mathrm{m} / \mathrm{z}$ calcd for $\mathrm{C}_{26} \mathrm{H}_{36} \mathrm{IN}_{2} \mathrm{O}_{4} \mathrm{Si}\left(\mathrm{M}+\mathrm{NH}_{4}\right)^{+}$595.1489, found 595.1492.
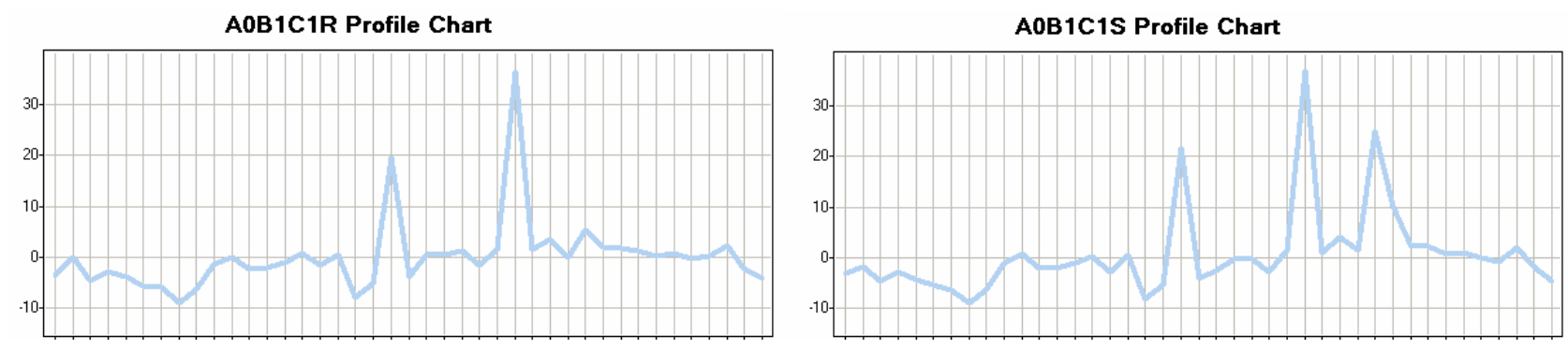


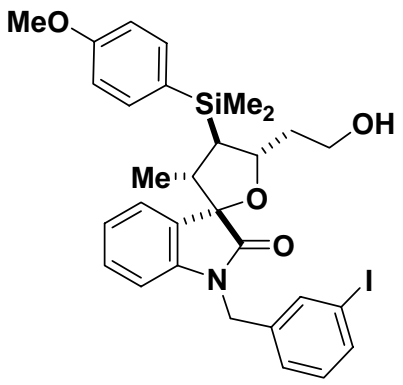

Spirocyclic annulation product hydroxyl-6j. The Method B procedure for the Lewis acid-mediated macrobead annulation and $\mathrm{Si}-\mathrm{O}$ cleavage was followed using $0.030 \mathrm{~g}$ of macrobead-supported crotylsilane $(R)$-3b $(0.033 \mathrm{mmol}), N$-(3-iodobenzyl)-isatin $5 \mathbf{j}(0.024 \mathrm{~g}, 0.066 \mathrm{mmol}), 0.132 \mathrm{~mL}$ of DTBMP solution ( $0.066 \mathrm{mmol}, 0.5 \mathrm{M}$ in $\mathrm{CH}_{2} \mathrm{Cl}_{2}$ ) and $0.132 \mathrm{~mL}$ of tin(IV) chloride solution (0.132 mmol, $1.0 \mathrm{M}$ in $\left.\mathrm{CH}_{2} \mathrm{Cl}_{2}\right)$ to yield the product as a colorless oil $(0.017 \mathrm{~g}$, 82\% over 3 steps from crotylsilane 3a): ${ }^{1} \mathrm{H}$ NMR (600 MHz, $\left.\mathrm{CDCl}_{3}\right) \delta 7.63(\mathrm{t}, J=1.6 \mathrm{~Hz}, 1 \mathrm{H}), 7.59(\mathrm{~d}, J=7.9 \mathrm{~Hz}, 1 \mathrm{H}), 7.45$ (d, $J=8.6 \mathrm{~Hz}, 2 \mathrm{H}), 7.22$ (d, $J=7.7 \mathrm{~Hz}, 1 \mathrm{H}), 7.19$ (dt, $J=7.8,1.1 \mathrm{~Hz}, 1 \mathrm{H}), 7.04$ (dt, $J=7.8,1.4 \mathrm{~Hz}$, 2H), 6.94 (d, $J=8.6 \mathrm{~Hz}, 2 \mathrm{H}$ ), 6.65 (d, $J=7.8 \mathrm{~Hz}, 1 \mathrm{H}$ ), 7.25 (d, $J=6.5 \mathrm{~Hz}, 1 \mathrm{H}), 4.99$ (d, $J=15.9 \mathrm{~Hz}$, $1 \mathrm{H}$ ), 4.62 (d, $J=15.9 \mathrm{~Hz}, 1 \mathrm{H}$ ), 4.56 (ddd, $J=11.4,9.1,2.7 \mathrm{~Hz}, 1 \mathrm{H}$ ), 3.82 (s, 3H), 3.72 (ddd, $J=11.5$, 7.7, $4.0 \mathrm{~Hz}, 1 \mathrm{H}$ ), 3.66 (m, 1H), 2.77 (qd, $J=13.6,6.8 \mathrm{~Hz}, 1 \mathrm{H}), 2.34$ (s, 1H), 1.72-162 (m, 2H), 1.49 (dd, $J=12.5,11.4 \mathrm{~Hz}, 1 \mathrm{H}), 0.57$ (d, $J=6.8 \mathrm{~Hz}, 3 \mathrm{H}), 0.431$ (s, 3H), 0.428 (s, 3H); 178.1, 160.7, 142.1, 138.0, 136.8, 136.0, 135.1, 130.5, 129.3, 128.9, 127.5, 126.3, 125.1, 122.9, 113.8, 109.1, 94.6, 86.7, 84.9, 61.3, 55.0, 46.5, 43.2, 40.7, 38.6, 14.9, -3.0, -3.5; HRMS (TOF MS ES ${ }^{+}$) $\mathrm{m} / \mathrm{z}$ calcd for $\mathrm{C}_{30} \mathrm{H}_{38} \mathrm{IN}_{2} \mathrm{O}_{4} \mathrm{Si}\left(\mathrm{M}+\mathrm{NH}_{4}\right)^{+}$645.1646, found 645.1627.
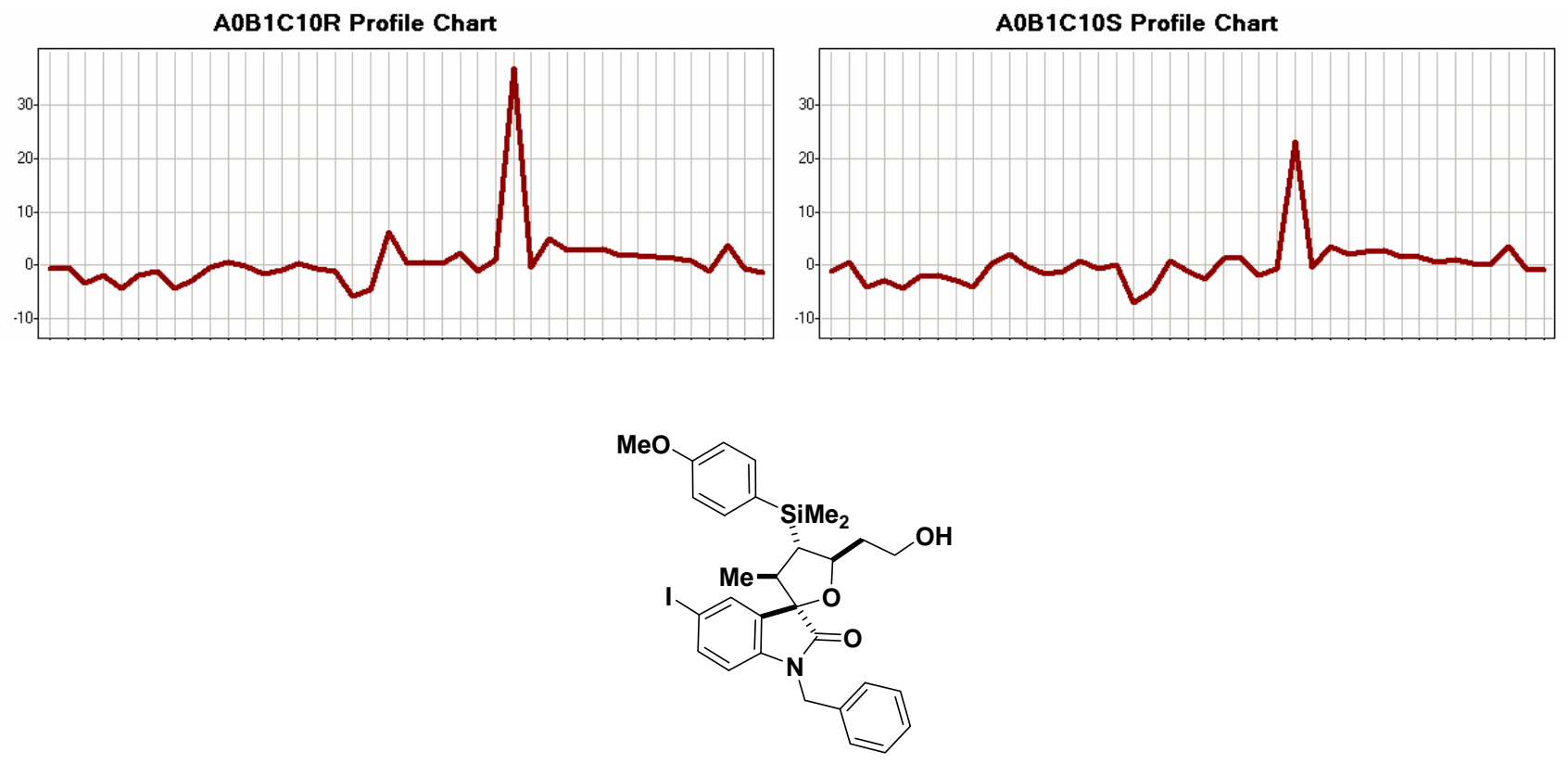

Spirocyclic annulation product hydroxyl-6k. The Method B procedure for Lewis acid-mediated macrobead annulation and $\mathrm{Si}-\mathrm{O}$ cleavage was followed using $0.090 \mathrm{~g}$ of macrobead supported crotylsilane $(R)$-3b $(0.099 \mathrm{mmol}$, in X-kans), $N$-benzyl-5-iodoisatin $5 \mathbf{k}(0.063 \mathrm{~g}, 0.173 \mathrm{mmol}), 0.200$ $\mathrm{mL}$ of DTBMP $\left(0.100 \mathrm{mmol}, 0.5 \mathrm{M}\right.$ in $\left.\mathrm{CH}_{2} \mathrm{Cl}_{2}\right)$ and $0.200 \mathrm{~mL}$ of tin(IV) chloride solution $(0.200$ mmol, $1.0 \mathrm{M}$ in $\left.\mathrm{CH}_{2} \mathrm{Cl}_{2}\right)$ to yield the product as a colorless oil $(0.043 \mathrm{~g}, 69 \%$ over 3 steps from crotylsilane 3a): ${ }^{1} \mathrm{H}$ NMR (600 MHz, $\mathrm{CDCl}_{3}$ ) $\delta$ 7.49-7.43 (m, 4H), $7.30(\mathrm{t}, J=7.2 \mathrm{~Hz}, 2 \mathrm{H}), 7.28-7.25$ 
(m, 1H), 7.23 (t, $J=6.5 \mathrm{~Hz}, 2 \mathrm{H}), 6.95(\mathrm{~d}, J=8.5 \mathrm{~Hz}, 1 \mathrm{H}), 6.44$ (d, $J=8.1 \mathrm{~Hz}, 1 \mathrm{H}), 4.98$ (d, $J=15.7$ Hz, 1H), 4.68 (d, $J=15.7 \mathrm{~Hz}, 1 \mathrm{H}$ ), 4.53 (ddd, $J=11.3,9.0,2.0 \mathrm{~Hz}, 1 \mathrm{H}$ ), 3.82 (s, 3H), 3.74-3.68 (m, $1 \mathrm{H}), 3.68-3.62(\mathrm{~m}, 1 \mathrm{H}), 2.75(\mathrm{dq}, J=13.7,6.8 \mathrm{~Hz}, 1 \mathrm{H}), 2.2(\mathrm{bs}, 1 \mathrm{H}), 1.71-1.58(\mathrm{~m}, 2 \mathrm{H}), 1.40(\mathrm{t}, J=$ $12.0 \mathrm{~Hz}, 1 \mathrm{H}), 0.58$ (d, $J=6.9 \mathrm{~Hz}, 3 \mathrm{H}), 0.44$ (s, 3H), 0.43 (s, 3H); ${ }^{13} \mathrm{C}$ NMR (100 MHz, $\left.\mathrm{CDCl}_{3}\right) \delta$ : 177.5, 160.8, 142.2, 138.0, 135.2, 135.1, 133.5, 131.5, 128.8, 127.7, 127.3, 127.1, 113.8, 111.4, 86.5, 85.4, 85.0, 61.3, 55.0, 46.7, 43.9, 40.9, 38.7, 15.0, -3.0, -3.5 ; ${ }^{29} \mathrm{Si}$ NMR (59 MHz, $\mathrm{CDCl}_{3}$ ) $\delta$ : -4.4 ; IR (method) 3462, 2948, 2916, 1721, 1594, $1108 \mathrm{~cm}^{-1}$; HRMS (TOF MS ES ${ }^{+}$) $\mathrm{m} / \mathrm{z}$ calcd for $\mathrm{C}_{30} \mathrm{H}_{38} \mathrm{IN}_{2} \mathrm{O}_{4} \mathrm{Si}\left(\mathrm{M}+\mathrm{NH}_{4}\right)^{+}$645.1646, found 645.1648.
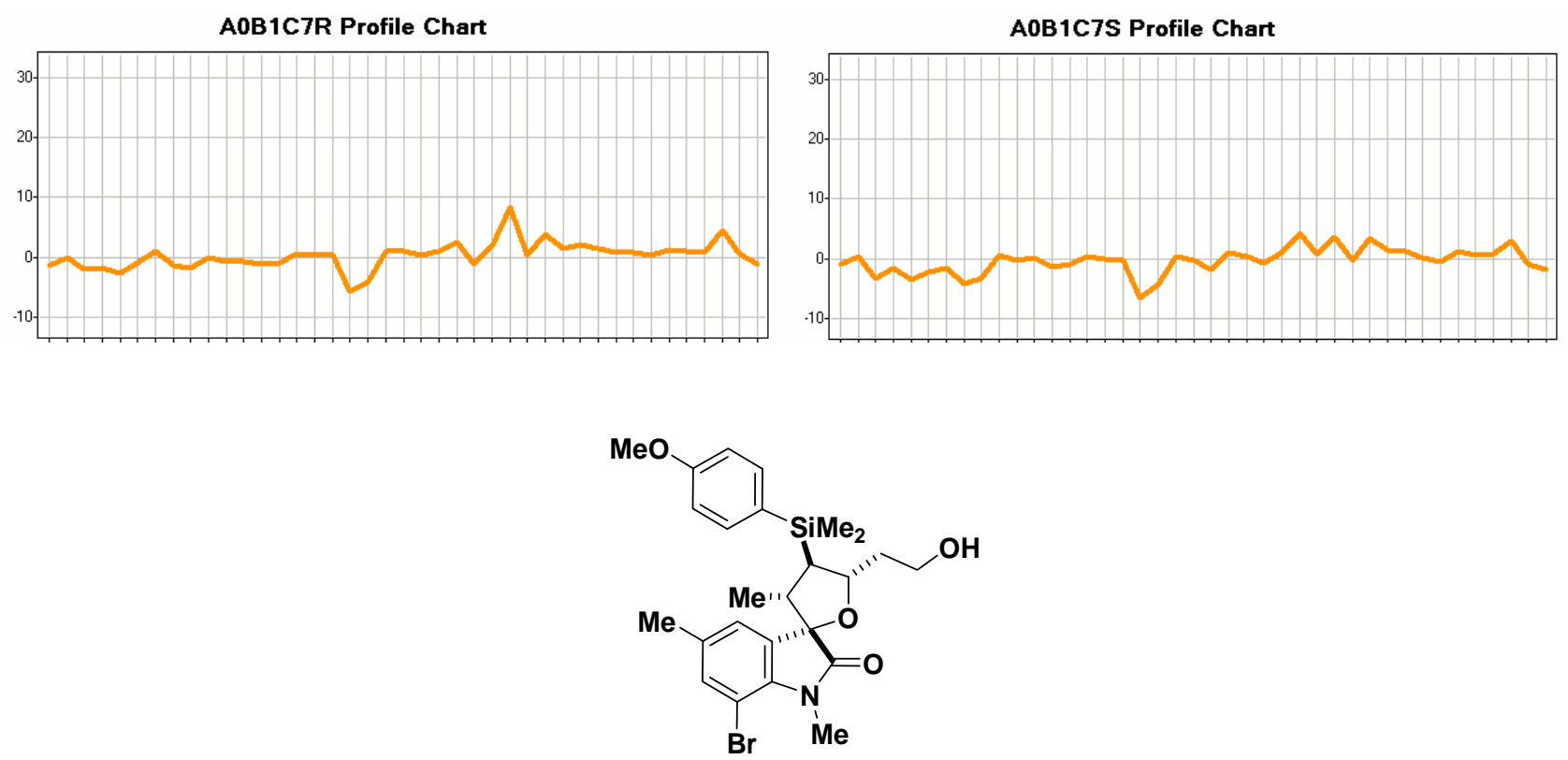

Spirocyclic annulation product hydroxyl-6b. The Method B procedure for the Lewis acid-mediated macrobead annulation and $\mathrm{Si}-\mathrm{O}$ cleavage was followed using $0.120 \mathrm{~g}$ of macrobead supported crotylsilane $(R)$-3b $(0.132 \mathrm{mmol}$, in X-kans), 7-bromo-1,5-dimethylisatin (5b) (0.134 g, $0.528 \mathrm{mmol})$, $0.264 \mathrm{~mL}$ of DTBMP $\left(0.132 \mathrm{mmol}, 0.5 \mathrm{M}\right.$ in $\left.\mathrm{CH}_{2} \mathrm{Cl}_{2}\right)$ and $0.264 \mathrm{~mL}$ of tin(IV) chloride solution $(0.264$ mmol, $1.0 \mathrm{M}$ in $\left.\mathrm{CH}_{2} \mathrm{Cl}_{2}\right)$ to yield the product as an colorless oil $(0.024 \mathrm{~g}, 35 \%$ over 3 steps from crotylsilane 3a): ${ }^{1} \mathrm{H}$ NMR $\left(500 \mathrm{MHz}, \mathrm{CDCl}_{3}\right) \delta 7.43(\mathrm{dd}, J=8.5,0.7 \mathrm{~Hz}, 2 \mathrm{H}), 7.20(\mathrm{td}, J=1.6,0.8$, $0.8 \mathrm{~Hz}, 1 \mathrm{H}$ ), 6.91 (s, 1H), 6.93 (dd, $J=8.5,0.7 \mathrm{~Hz}, 2 \mathrm{H}$ ), 4.50 (ddd, $J=11.4,9.4,2.3 \mathrm{~Hz}, 1 \mathrm{H}$ ), 3.81 (d, $J=0.7 \mathrm{~Hz}, 3 \mathrm{H}$ ), 3.64 (bs, 1H), 3.69 (ddd, $J=11.5,7.8,4.0 \mathrm{~Hz}, 1 \mathrm{H}$ ), 3.52 (d, $J=0.7 \mathrm{~Hz}, 3 \mathrm{H}$ ), 2.35 (bs, $1 \mathrm{H}), 2.67$ (qd, $J=13.3,6.9,6.8,6.8 \mathrm{~Hz}, 1 \mathrm{H}), 2.29(\mathrm{~s}, 3 \mathrm{H}), 1.70-1.56(\mathrm{~m}, 3 \mathrm{H}), 1.36$ (t, $J=11.9$, $1 \mathrm{H}), 0.53(\mathrm{~d}, J=6.8 \mathrm{~Hz}, 3 \mathrm{H}), 0.41(\mathrm{~s}, 6 \mathrm{H}) ;{ }^{13} \mathrm{C}$ NMR $\left(125 \mathrm{MHz}, \mathrm{CDCl}_{3}\right) \delta 178.7,160.7,138.2,135.1$, 134.9, 133.6, 132.2, 127.4, 124.8, 113.8, 102.3, 86.2, 84.9, 61.3, 55.0, 46.7, 40.9, 38.4, 29.8, 20.5, 15.1, -3, -3.6; LCMS (EI) $\mathrm{m} / \mathrm{z}$ calcd for $\mathrm{C}_{25} \mathrm{H}_{32} \mathrm{BrNO}_{4} \mathrm{Si}\left(\mathrm{M}+\mathrm{NH}_{4}\right)^{+} 535.16$, found 535.15.
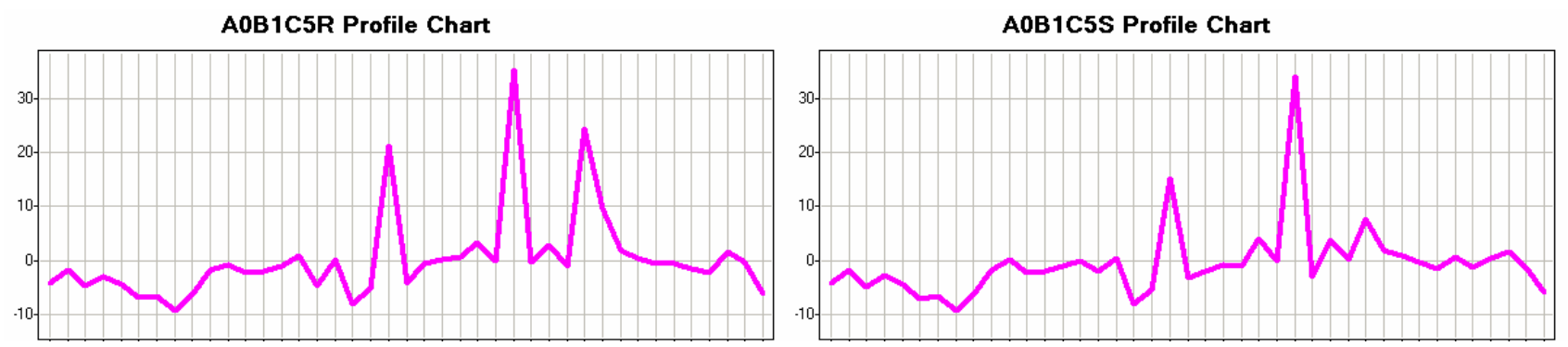
Representative spirocyclic products derived from annulation with triazole crotylsilane 4:

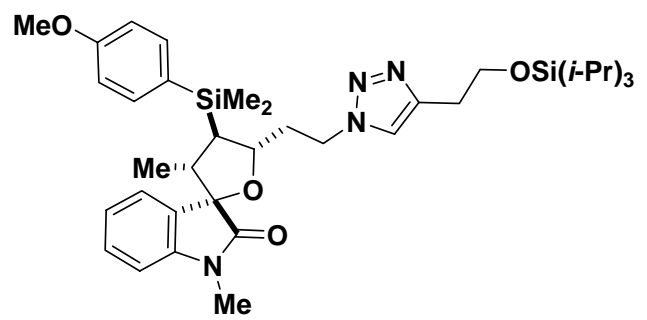

Spirocyclic annulation product TIPS-protected triazole-6c. The Method A procedure for tin(IV) chloride mediated annulations was followed using $0.600 \mathrm{~g}(1.16 \mathrm{mmol})$ of racemic TIPS-protected triazole crotylsilane 4, $N$-methylisatin $5 c(0.280 \mathrm{~g}, 1.74 \mathrm{mmol})$, and $1.4 \mathrm{~mL}$ of tin(IV) chloride $(1.4$ mmol, $1.0 \mathrm{M}$ in $\mathrm{CH}_{2} \mathrm{Cl}_{2}$ ). The resulting material was purified by flash chromatography to yield the product as a colorless oil $(0.674 \mathrm{~g}, 86 \%):{ }^{1} \mathrm{H}$ NMR $\left(500 \mathrm{MHz}, \mathrm{CDCl}_{3}\right) \delta 7.36(\mathrm{td}, J=8.4,1.9 \mathrm{~Hz}, 2 \mathrm{H})$, 7.25 (dt, $J=7.7,1.1 \mathrm{~Hz}, 1 \mathrm{H}), 7.20$ (s, 1H), 7.15-7.11 (m, $1 \mathrm{H}), 7.02$ (t, $J=7.5 \mathrm{~Hz}, 1 \mathrm{H}), 6.88$ (td, $J=$ 8.4, $1.8 \mathrm{~Hz}, 2 \mathrm{H}$ ), 6.78 (d, $J=7.7 \mathrm{~Hz}, 1 \mathrm{H}$ ), 4.40 (ddd, $J=13.7,9.2,4.7 \mathrm{~Hz}, 1 \mathrm{H}$ ), 4.29 (ddd, $J=11.1$, 9.7, $1.6 \mathrm{~Hz}, 1 \mathrm{H}$ ), 4.20 (td, $J=13.8,7.9 \mathrm{~Hz}, 1 \mathrm{H}), 3.90$ (dt, $J=9.5,2.8 \mathrm{~Hz}, 2 \mathrm{H}), 3.76$ (s, 3H), 3.13 (s, 3H), $2.91(\mathrm{t}, J=6.8 \mathrm{~Hz}, 2 \mathrm{H}), 2.69(\mathrm{qd}, J=13.7,6.8 \mathrm{~Hz}, 1 \mathrm{H}), 1.97(\mathrm{dtd}, J=13.9,8.8,1.1 \mathrm{~Hz}, 1 \mathrm{H})$, 1.83 (ddt, $J=14.0,9.1,4.8 \mathrm{~Hz}, 1 \mathrm{H}), 1.36(\mathrm{t}, J=11.9 \mathrm{~Hz}, 1 \mathrm{H}), 1.06(\mathrm{~m}, 3 \mathrm{H}), 1.01$ (d, $J=6.3 \mathrm{~Hz}$, $18 \mathrm{H}), 0.52$ (d, $J=6.8 \mathrm{~Hz}, 3 \mathrm{H}), 0.355$ (s, 6H), 0.345 (s, 3H); ${ }^{13} \mathrm{C}$ NMR $\left(100 \mathrm{MHz}, \mathrm{CDCl}_{3}\right) \delta 177.5$, 160.4, 144.4, 143.1, 134.7, 129.0, 128.6, 126.8, 124.4, 122.2, 121.7, 113.6, 108.0, 86.3, 80.8, 77.2, 76.9, 76.7, 62.4, 54.6, 47.1, 46.2, 40.0, 36.8, 29.2, 25.9, 17.6, 14.6, 11.5, -3.5, -4.1; ${ }^{29} \mathrm{Si}$ NMR (59 $\mathrm{MHz} \mathrm{CDCl}_{3}$ ) $\delta 13.1,-4.7$; IR 2928, 2857, 1740, 1716, 1610, $1471 \mathrm{~cm}^{-1}$; HRMS (TOF MS ES ${ }^{+}$m/z calcd for $\mathrm{C}_{37} \mathrm{H}_{57} \mathrm{~N}_{4} \mathrm{O}_{4} \mathrm{Si}_{2}(\mathrm{M}+\mathrm{H})^{+}$677.3918, found 677.3906.

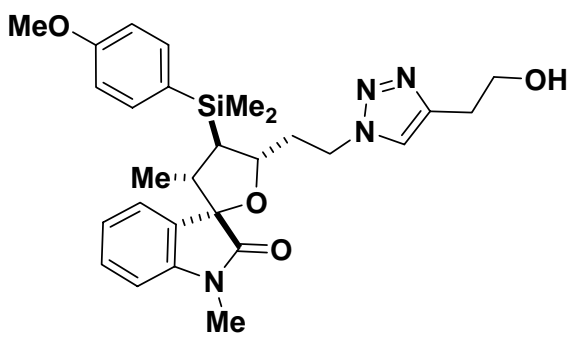

Spirocyclic annulation product triazole-6c. The Method B procedure for the Lewis acid-mediated macrobead annulation and Si-O cleavage was followed using $0.030 \mathrm{~g}$ of macrobead-supported crotylsilane $(R)-4(0.033 \mathrm{mmol}), N$-methylisatin $5 c(0.021 \mathrm{~g}, 0.132 \mathrm{mmol}), 0.066 \mathrm{~mL}$ of DTBMP (0.033 mmol, $0.5 \mathrm{M}$ in $\mathrm{CH}_{2} \mathrm{Cl}_{2}$ ) and $0.066 \mathrm{~mL}$ of tin(IV) chloride solution (0.066 mmol, $1.0 \mathrm{M}$ in $\mathrm{CH}_{2} \mathrm{Cl}_{2}$ ) to yield the product as a colorless oil ( $9.0 \mathrm{mg}, 52 \%$ over 4 steps from 1-butynol): ${ }^{1} \mathrm{H} \mathrm{NMR}$ $\left(600 \mathrm{MHz}, \mathrm{CDCl}_{3}\right) \delta 7.36$ (td, $\left.J=8.6,1.9 \mathrm{~Hz}, 2 \mathrm{H}\right), 7.31$ (dt, $\left.J=7.7,1.1 \mathrm{~Hz}, 1 \mathrm{H}\right), 7.27$ (s, 1H), 7.17 (d, $J=7.3, \mathrm{~Hz}, 1 \mathrm{H}), 7.06(\mathrm{dt}, J=7.6,1.0 \mathrm{~Hz}, 1 \mathrm{H}), 6.91(\mathrm{~d}, J=8.6,1.9 \mathrm{~Hz}, 2 \mathrm{H}), 6.82(\mathrm{~d}, J=7.7 \mathrm{~Hz}, 1 \mathrm{H})$, 4.44 (ddd, $J=13.5,8.1,4.3 \mathrm{~Hz}, 1 \mathrm{H}$ ), 4.23 (td, $J=13.7,8.0 \mathrm{~Hz}, 1 \mathrm{H}$ ), 4.13 (ddd, $J=11.9,10.2,1.9 \mathrm{~Hz}$, 1H), 3.96-3.87 (m, 2H), 3.83 (s, 3H), 3.18 (s, 3H), 2.93 (td, $J=6.4,4.7 \mathrm{~Hz}, 2 \mathrm{H}$ ), 2.68 (qd, $J=13.7$, $6.8 \mathrm{~Hz}, 1 \mathrm{H}$ ), 1.94 (ddt, $J=10.0,8.3,1.7 \mathrm{~Hz}, 1 \mathrm{H}$ ), 1.79 (dddd, $J=11.7,9.8,7.4,4.3 \mathrm{~Hz}, 1 \mathrm{H}$ ), 1.33 (dd, $J=12.4,11.3 \mathrm{~Hz}, 1 \mathrm{H}), 0.56$ (d, $J=6.9 \mathrm{~Hz}, 3 \mathrm{H}), 0.36$ (s, 3H), 0.35 (s, 3H); ${ }^{13} \mathrm{C}$ NMR $(100 \mathrm{MHz}$, $\left.\mathrm{CDCl}_{3}\right) \delta 178.3,160.7,145.1,143.4,135.1,129.4,128.9,127.2,124.7,122.6,122.4,113.9,108.4$, 86.4, 80.7, 61.5, 55.0, 47.6, 46.4, 40.6, 36.6, 28.6, 26.3, 15.2, -3.0, -4.0; HRMS (TOF MS ES ${ }^{+}$) m/z calcd for $\mathrm{C}_{28} \mathrm{H}_{37} \mathrm{~N}_{4} \mathrm{O}_{4} \mathrm{Si}(\mathrm{M}+\mathrm{H})^{+}$521.2584, found 521.2599. 

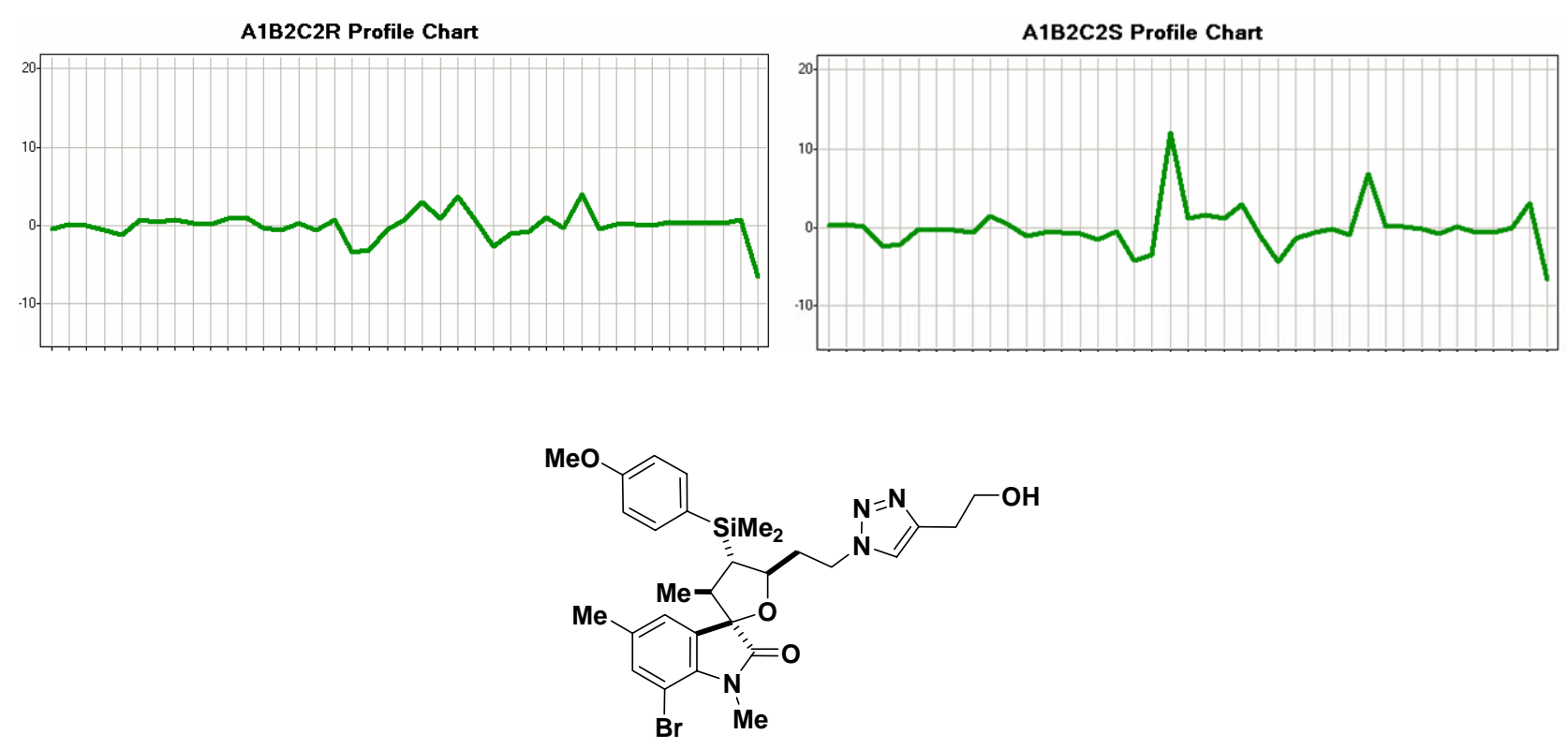

Spirocyclic annulation product triazole-6b (11). The Method B procedure for the Lewis acidmediated macrobead annulation and $\mathrm{Si}-\mathrm{O}$ cleavage was followed using $0.120 \mathrm{~g}$ of macrobead supported crotylsilane (S)-4 (0.132 mmol, in X-kans), 7-bromo-1,5-dimethylisatin (5b) (0.134 g, 0.528 $\mathrm{mmol}), 0.264 \mathrm{~mL}$ of DTBMP $\left(0.132 \mathrm{mmol}, 0.5 \mathrm{M}\right.$ in $\left.\mathrm{CH}_{2} \mathrm{Cl}_{2}\right)$ and $0.264 \mathrm{~mL}$ of tin(IV) chloride solution $\left(0.264 \mathrm{mmol}, 1.0 \mathrm{M}\right.$ in $\left.\mathrm{CH}_{2} \mathrm{Cl}_{2}\right)$ to yield the product as an colorless oil $(0.054 \mathrm{~g}, 67 \%$ over 4 steps from 1-butynol): ${ }^{1} \mathrm{H}$ NMR (500 MHz, $\left.\mathrm{CDCl}_{3}\right) \delta 7.34$ (dd, $\left.J=8.6,0.9 \mathrm{~Hz}, 2 \mathrm{H}\right), 7.25$ (s, $1 \mathrm{H}$ ), 6.91 (dd, $J=8.6,0.9 \mathrm{~Hz}, 2 \mathrm{H}), 7.22$ (s, $1 \mathrm{H}), 6.86(\mathrm{~s}, 1 \mathrm{H}), 4.44$ (ddd, $J=12.8,8.0,4.3 \mathrm{~Hz}, 1 \mathrm{H}$ ), 4.20 (td, $J=$ 13.9, 7.9, $7.9 \mathrm{~Hz}, 1 \mathrm{H}$ ), 4.11 (ddd, $J=11.2,8.0,4.1 \mathrm{~Hz}, 1 \mathrm{H}$ ), 3.91 (qd, $J=17.3,5.5,5.5,5.5 \mathrm{~Hz}, 2 \mathrm{H}$ ), 3.82 (d, $J=0.9 \mathrm{~Hz}, 3 \mathrm{H}), 3.52$ (d, $J=0.9 \mathrm{~Hz}, 3 \mathrm{H}), 2.92$ (dt, $J=6.1,5.8,2.5 \mathrm{~Hz}, 2 \mathrm{H}$ ), 2.66 (qd, $J=$ 13.7, 6.9, 6.8, $6.8 \mathrm{~Hz}, 1 \mathrm{H}), 2.30(\mathrm{~s}, 3 \mathrm{H}), 1.97-1.89(\mathrm{~m}, 1 \mathrm{H}), 1.82-1.73(\mathrm{~m}, 1 \mathrm{H}), 1.252$ (ddd, $J=7.1$, 6.6, $1.0 \mathrm{~Hz}, 1 \mathrm{H}), 1.246$ (t, $J=11.9,11.9 \mathrm{~Hz}, 1 \mathrm{H}), 0.55$ (d, $J=6.9 \mathrm{~Hz}, 3 \mathrm{H}), 0.35(\mathrm{~s}, 6 \mathrm{H}) ;{ }^{13} \mathrm{C}$ NMR $\left(125 \mathrm{MHz}, \mathrm{CDCl}_{3}\right) \delta 179.1,160.8,145.2,138.2,135.1,135.0,133.7,132.1,127.1,124.8,122.3,113.9$, 102.4, 85.8, 80.9, 61.6, 55.0, 47.4, 46.9, 40.7, 36.4, 29.8, 28.7, 20.5, 15.4, -3, -4.1; LCMS (EI) $\mathrm{m} / \mathrm{z}$ calcd for $\mathrm{C}_{29} \mathrm{H}_{37} \mathrm{BrN}_{4} \mathrm{O}_{4} \mathrm{Si}(\mathrm{M}+\mathrm{H})^{+}$613.18, found 613.13.
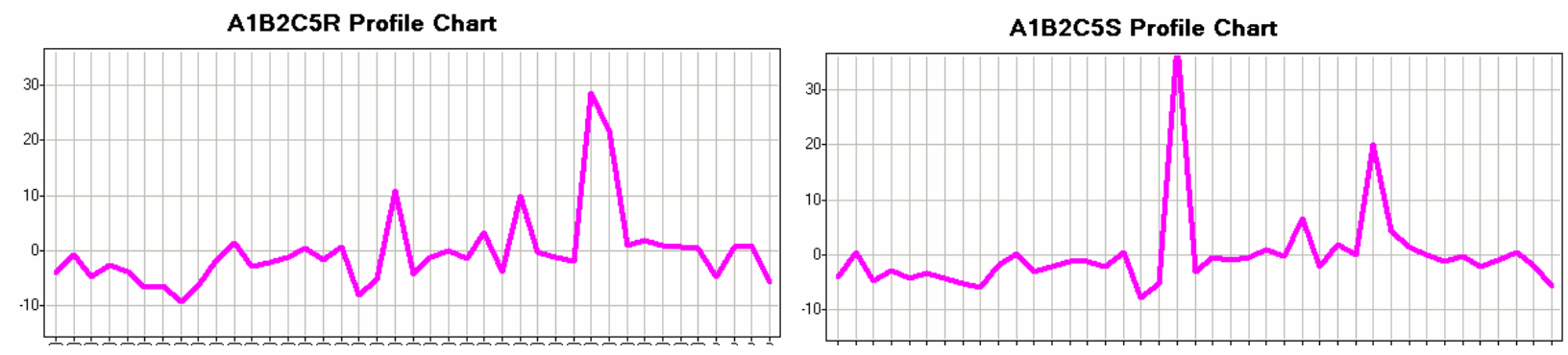


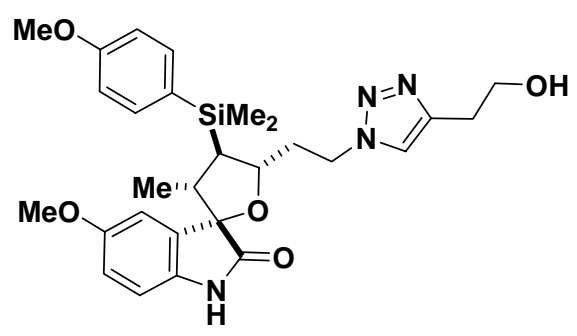

Spirocyclic annulation product triazole-6e. The representative procedure for the Lewis acidmediated macrobead annulation and Si-O cleavage was followed using $0.060 \mathrm{~g}$ of macrobead supported crotylsilane $(R)-4$ (0.066 mmol, in X-kans), 5-methoxyisatin 5e (0.047 g, $0.264 \mathrm{mmol})$, $0.132 \mathrm{~mL}$ of DTBMP $\left(0.066 \mathrm{mmol}, 0.5 \mathrm{M}\right.$ in $\left.\mathrm{CH}_{2} \mathrm{Cl}_{2}\right)$ and $0.132 \mathrm{~mL}$ of tin(IV) chloride solution (0.132 mmol, $1.0 \mathrm{M}$ in $\mathrm{CH}_{2} \mathrm{Cl}_{2}$ ) to yield the product as a white solid (19.2 mg, 54\% over 4 steps from 1butynol): ${ }^{1} \mathrm{H}$ NMR (500 MHz, $\left.\mathrm{CDCl}_{3}\right) \delta 8.36$ (bs, $\left.1 \mathrm{H}\right), 7.35$ (d, $\left.J=8.6 \mathrm{~Hz}, 2 \mathrm{H}\right), 7.26(\mathrm{~s}, 1 \mathrm{H}$, overlapping with $\mathrm{CDCl}_{3}$ ), $6.91(\mathrm{~d}, J=8.6 \mathrm{~Hz}, 2 \mathrm{H}), 6.82-6.75(\mathrm{~m}, 3 \mathrm{H}), 4.44$ (ddd, $J=13.1,7.9,4.3$ Hz, 1H), 4.24 (td, $J=13.7,7.9,7.9 \mathrm{~Hz}, 1 \mathrm{H}$ ), 4.13 (ddd, $J=11.6,10.3,1.8 \mathrm{~Hz}, 1 \mathrm{H}), 3.96-3.86$ (m, 2H), 3.82 (s, 3H), 3.80 (s, 3H), 3.07 (bs, $1 \mathrm{H}), 2.92$ (dt, $J=5.9,5.8,2.2 \mathrm{~Hz}, 2 \mathrm{H}), 2.66$ (qd, $J=13.6,6.9 \mathrm{~Hz}$, $1 \mathrm{H}$ ), 1.94 (ddt, $J=9.8,8.2,1.6 \mathrm{~Hz}, 1 \mathrm{H}$ ), 1.79 (ddt, $J=14.1,7.3,4.4 \mathrm{~Hz}, 1 \mathrm{H}$ ), 1.31 (dd, $J=12.4,11.3$ $\mathrm{Hz}, 1 \mathrm{H}), 0.62$ (d, $J=6.9 \mathrm{~Hz}, 3 \mathrm{H}), 0.36$ (s, 3H), 0.35 (s, 3H); ${ }^{13} \mathrm{C}$ NMR $\left(125 \mathrm{MHz}, \mathrm{CDCl}_{3}\right) \delta 180.4$, 160.7, 155.7, 145.1, 135.0, 133.9, 130.8, 127.2, 122.3, 113.9, 113.1, 112.8, 110.6, 87.1, 81.0, 61.6, 55.8, 55.0, 47.4, 46.6, 40.3, 36.7, 28.7, 14.9, -3.1, -4.0; LCMS (EI or APCI) $\mathrm{m} / \mathrm{z}$ calcd for $\mathrm{C}_{28} \mathrm{H}_{37} \mathrm{~N}_{4} \mathrm{O}_{5} \mathrm{Si}(\mathrm{M}+\mathrm{H})^{+}$537.25, found 537.16.

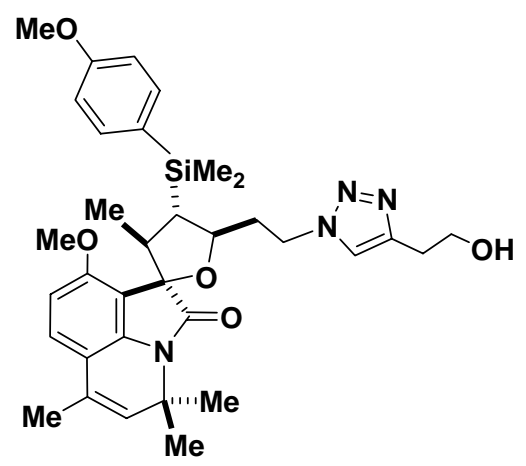

Spirocyclic annulation product triazole-6a (12). The Method B procedure for the Lewis acidmediated macrobead annulation and $\mathrm{Si}-\mathrm{O}$ cleavage was followed using $0.090 \mathrm{~g}$ of macrobeadsupported crotylsilane (S)-4 (0.099 in X-kans), isatin 5a (0.045 g, $0.175 \mathrm{mmol})$, DTBMP (0.020g, $0.100 \mathrm{mmol}$ ) and $0.20 \mathrm{~mL}$ of tin(IV) chloride solution $\left(0.200 \mathrm{mmol}, 1.0 \mathrm{M}\right.$ in $\left.\mathrm{CH}_{2} \mathrm{Cl}_{2}\right)$ to yield the product as an colorless oil $\left(0.038 \mathrm{~g}, 62 \%\right.$ over 3 steps from crotylsilane 3a): ${ }^{1} \mathrm{H}$ NMR $(500 \mathrm{MHz}$, $\left.\mathrm{CDCl}_{3}\right) \delta 7.38$ (dd, $\left.J=8.63,1.05 \mathrm{~Hz}, 2 \mathrm{H}\right), 7.21$ (s, $\left.1 \mathrm{H}\right), 6.99$ (d, $\left.J=8.49 \mathrm{~Hz}, 1 \mathrm{H}\right), 6.91$ (dd, $J=8.69$, $1.04 \mathrm{~Hz}, 2 \mathrm{H}), 6.44$ (d, $J=8.54 \mathrm{~Hz}, 1 \mathrm{H}), 5.09$ (t, $J=1.1 \mathrm{~Hz}, 1 \mathrm{H}), 4.42$ (td, $J=13.42,6.61 \mathrm{~Hz}, 1 \mathrm{H})$, 4.26 (td, $J=13.73,7.86 \mathrm{~Hz}, 1 \mathrm{H}), 4.16$ (ddd, $J=11.10,5.92,4.72 \mathrm{~Hz}, 1 \mathrm{H}), 3.95-3.85$ ( m, $2 \mathrm{H}$ ), 3.82 (s, 3H), 3.81 (s, 3H), $2.90(\mathrm{~m}, 2 \mathrm{H}), 2.71$ (qd, $J=13.71,6.80 \mathrm{~Hz}, 1 \mathrm{H}), 1.96(\mathrm{~s}, 3 \mathrm{H}), 1.90$ (td, $J=7.50$, $5.86 \mathrm{~Hz}, 2 \mathrm{H}), 1.75$ (t, $J=11.94 \mathrm{~Hz}, 2 \mathrm{H}), 1.66-1.62(\mathrm{~m}, 3 \mathrm{H}), 1.61(\mathrm{~s}, 3 \mathrm{H}), 0.68$ (d, $J=6.88 \mathrm{~Hz}, 3 \mathrm{H})$, 0.36 (s, 3H), 0.34 (s, 3H); ${ }^{13} \mathrm{C}$ NMR (100 MHz, $\left.\mathrm{CDCl}_{3}\right) \delta 179.0,160.6,155.9,145.1,140.6,135.3$, 135.0, 128.1, 124.7, 124.3, 122.0, 113.8, 113.3, 112.4, 104.7, 88.5, 82.0, 61.6, 56.4, 55.0, 55.0, 47.4, 46.2, 39.9, 35.4, 28.6, 27.5, 27.3, 17.5, 14.7, -3.0, -4.0; LCMS (TOF MS ES ${ }^{+}$) $\mathrm{m} / \mathrm{z}$ calcd for $\mathrm{C}_{30} \mathrm{H}_{39} \mathrm{NO}_{5} \mathrm{Si}(\mathrm{M}+\mathrm{H})^{+}$617.31, found 617.09. 


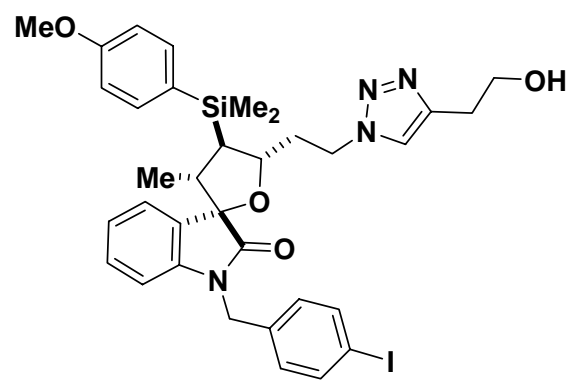

Spirocyclic annulation product triazole-6i. The method B procedure for the Lewis acid-mediated macrobead annulation and $\mathrm{Si}-\mathrm{O}$ cleavage was followed using $0.030 \mathrm{~g}$ of macrobead-supported triazole crotylsilane $(R)-4(0.033 \mathrm{mmol}), N$-(4-iodobenzyl)isatin $5 \mathbf{i}(0.048 \mathrm{~g}, 0.132 \mathrm{mmol}), 0.132 \mathrm{~mL}$ of DTBMP (0.066 mmol, $0.5 \mathrm{M}$ in $\mathrm{CH}_{2} \mathrm{Cl}_{2}$ ) and $0.132 \mathrm{~mL}$ of tin(IV) chloride solution (0.132 mmol, 1.0 $\mathrm{M}$ in $\left.\mathrm{CH}_{2} \mathrm{Cl}_{2}\right)$ to yield the product as a colorless oil (0.012 g, 51\% over 4 steps from 1-butynol): ${ }^{1} \mathrm{H}$ NMR (600 MHz, $\left.\mathrm{CDCl}_{3}\right) \delta 7.64(\mathrm{~d}, J=8.3 \mathrm{~Hz}, 2 \mathrm{H}), 7.37(\mathrm{~d}, J=8.5 \mathrm{~Hz}, 2 \mathrm{H}), 7.23(\mathrm{~s}, 1 \mathrm{H}), 7.19(\mathrm{t}, J=$ $6.5 \mathrm{~Hz}, 2 \mathrm{H}), 7.03$ (t, $J=7.4 \mathrm{~Hz}, 3 \mathrm{H}), 6.92$ (d, $J=8.4 \mathrm{~Hz}, 2 \mathrm{H}), 6.66$ (d, $J=8.2 \mathrm{~Hz}, 1 \mathrm{H}), 4.94$ (d, $J=$ $15.8 \mathrm{~Hz}, 1 \mathrm{H}$ ), 4.67 (d, $J=15.8 \mathrm{~Hz}, 1 \mathrm{H}$ ), 4.45 (ddd, $J=13.1$, 8.4, $4.4 \mathrm{~Hz}, 1 \mathrm{H}$ ), 4.26-4.17 (m, 2H), 3.91 (tdd, $J=16.1,10.7,5.5 \mathrm{~Hz}, 2 \mathrm{H}$ ), $3.82(\mathrm{~s}, 3 \mathrm{H}), 2.91$ (t, $J=5.7 \mathrm{~Hz}, 2 \mathrm{H}), 2.82$ (bs, 1H), 2.75 (qd, $J=$ 13.7, $6.8 \mathrm{~Hz}, 1 \mathrm{H}), 1.96(\mathrm{td}, J=14.8,8.3 \mathrm{~Hz}, 1 \mathrm{H}), 1.85-1.78(\mathrm{~m}, 1 \mathrm{H}), 1.37(\mathrm{t}, J=11.9 \mathrm{~Hz}, 1 \mathrm{H}), 0.57$ (d, $J=6.8 \mathrm{~Hz}, 3 \mathrm{H}), 0.38(\mathrm{~s}, 6 \mathrm{H})$; HRMS $\left(\right.$ TOF MS ES $\left.{ }^{+}\right) \mathrm{m} / \mathrm{z}$ calcd for $\mathrm{C}_{34} \mathrm{H}_{43} \mathrm{IN}_{5} \mathrm{O}_{4} \mathrm{Si}\left(\mathrm{M}+\mathrm{NH}_{4}\right)^{+}$ 723.1863, found 723.1845 .
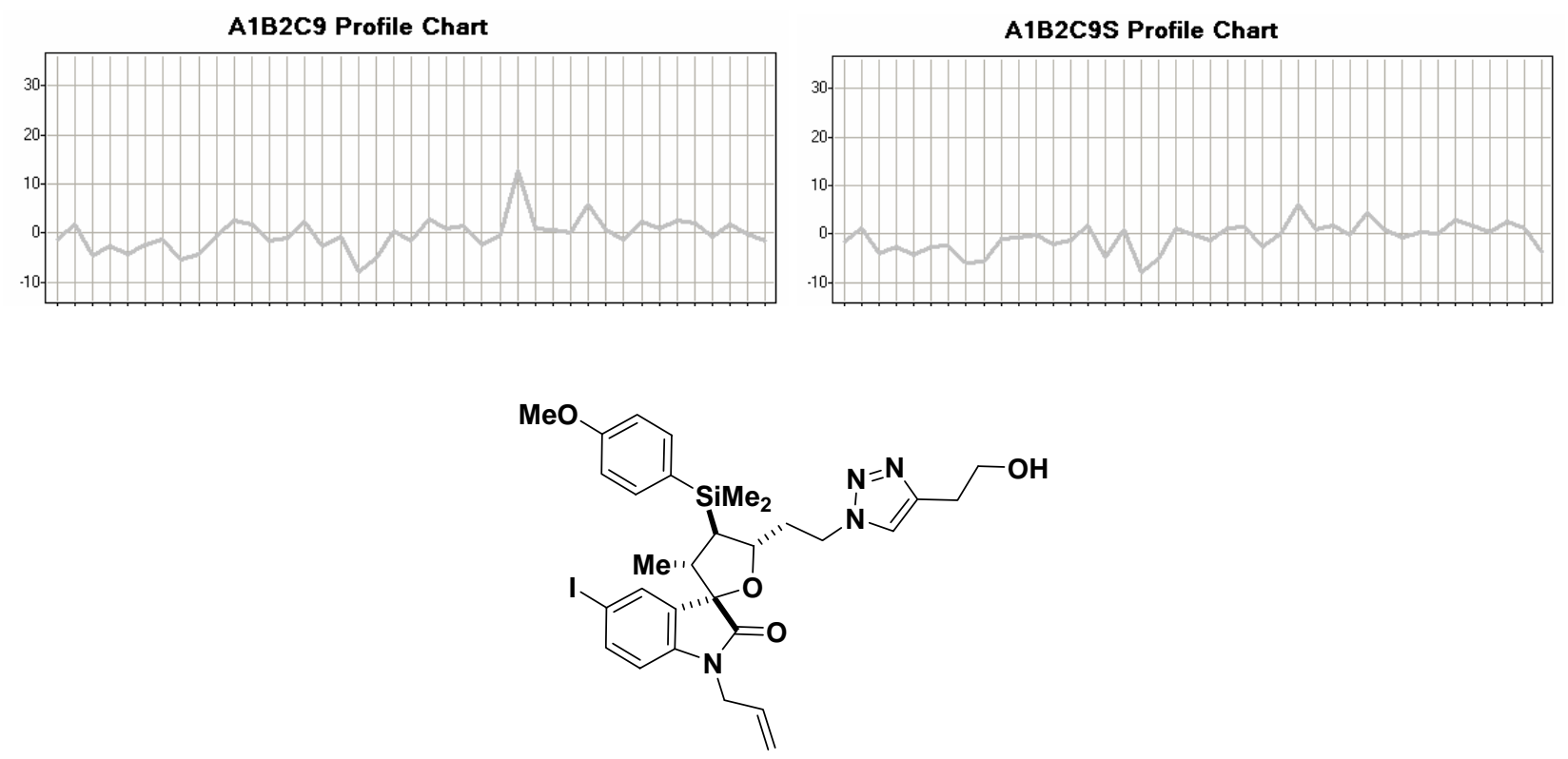

Spirocyclic annulation product triazole-6f. The Method B procedure for the Lewis acid-mediated macrobead annulation and Si-O cleavage was followed using $0.030 \mathrm{~g}$ of macrobead-supported triazole crotylsilane $(R)-4(0.033 \mathrm{mmol}), N$-allyl-5-iodoisatin $\mathbf{5 f}(0.042 \mathrm{~g}, 0.132 \mathrm{mmol}), 0.132 \mathrm{~mL}$ of DTBMP (0.066 mmol, $0.5 \mathrm{M}$ in $\mathrm{CH}_{2} \mathrm{Cl}_{2}$ ) and $0.132 \mathrm{~mL}$ of tin(IV) chloride solution (0.132 mmol, $1.0 \mathrm{M}$ in $\mathrm{CH}_{2} \mathrm{Cl}_{2}$ ) to yield the product as a pale yellow oil (14.6 mg, $66 \%$ over 4 steps from 1-butynol): ${ }^{1} \mathrm{H}$ NMR $\left(500 \mathrm{MHz}, \mathrm{CDCl}_{3}\right) \delta 7.58$ (dd, $\left.J=8.2,1.4 \mathrm{~Hz}, 1 \mathrm{H}\right), 7.41$ (d, $\left.J=1.7 \mathrm{~Hz}, 1 \mathrm{H}\right), 7.35$ (d, $J=8.3 \mathrm{~Hz}, 2 \mathrm{H}$ ), 7.25 (s, 2H), 6.91 (d, $J=8.2 \mathrm{~Hz}, 2 \mathrm{H}$ ), 6.59 (d, $J=8.2 \mathrm{~Hz}, 1 \mathrm{H}$ ), 5.78 (ddd, $J=22.3,10.3,5.2 \mathrm{~Hz}, 1 \mathrm{H}$ ), 
5.20 (dd, $J=18.7,13.8 \mathrm{~Hz}, 2 \mathrm{H}), 4.46-4.36$ ( m, 2H), 4.22 (td, $J=13.7,8.0 \mathrm{~Hz}, 1 \mathrm{H}), 4.16-4.08$ (m, 2H), 3.92 (ddt, $J=15.9,10.4,5.0 \mathrm{~Hz}, 2 \mathrm{H}$ ), 3.82 (s, 3H), 2.92 (dt, $J=6.5,2.3 \mathrm{~Hz}, 2 \mathrm{H}$ ), 2.67 (qd, $J=$ 13.7, $6.9 \mathrm{~Hz}, 1 \mathrm{H}), 1.96$ (tt, $J=8.4,6.9 \mathrm{~Hz}, 1 \mathrm{H}), 1.77$ (ddt, $J=14.0,7.3,4.2 \mathrm{~Hz}, 1 \mathrm{H}$ ), 1.67 (dd, $J=$ 12.9, $5.7 \mathrm{~Hz}, 1 \mathrm{H}), 0.59(\mathrm{~d}, J=6.9 \mathrm{~Hz}, 3 \mathrm{H}), 0.362(\mathrm{~s}, 3 \mathrm{H}), 0.355(\mathrm{~s}, 3 \mathrm{H}) ;{ }^{13} \mathrm{C} \mathrm{NMR}(125 \mathrm{MHz}$, $\left.\mathrm{CDCl}_{3}\right) \delta 177.5,160.8,145.2,142.3,138.1,135.1,133.4,131.4,130.7,126.9,122.2,117.8,114.0$, 111.4, 86.1, 85.3, 81.1, 61.6, 55.0, 47.4, 46.8, 42.4, 40.7, 36.5, 28.7, 15.4, -3.0, -4.0; LCMS (EI) m/z calcd for $\mathrm{C}_{41} \mathrm{H}_{43} \mathrm{~N}_{5} \mathrm{O}_{5} \mathrm{Si}(\mathrm{M}+\mathrm{H})^{+}$673.17, found 673.15.
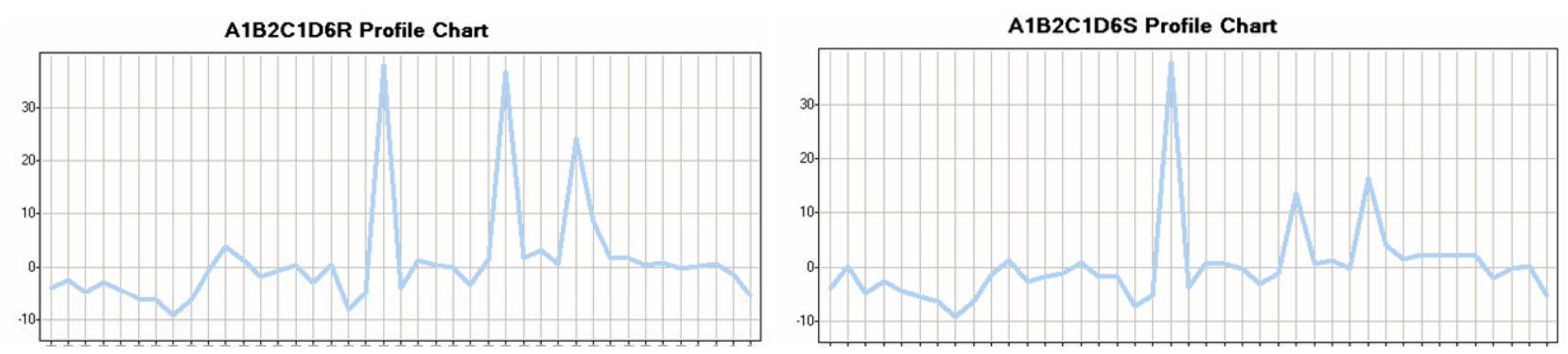

Representative spirocyclic products derived from annulation with amido-crotylsilane 2:

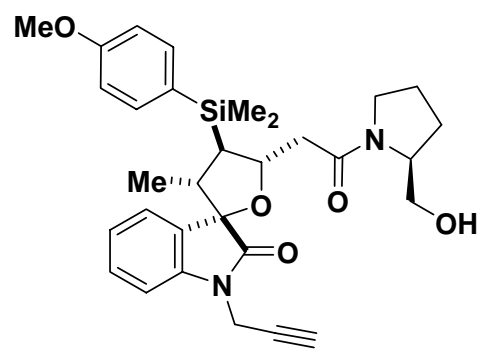

Spirocyclic annulation product amide-6g. The method B procedure for the Lewis acid-mediated macrobead annulation and $\mathrm{Si}-\mathrm{O}$ cleavage was followed using $0.090 \mathrm{~g}$ (in X-kans) of macrobeadsupported amido-crotylsilane $(R)$-2, $N$-propargylisatin $5 \mathrm{~g}(0.067 \mathrm{~g}, 0.36 \mathrm{mmol}), 0.360 \mathrm{~mL}$ of DTBMP (0.180 mmol, $0.5 \mathrm{M}$ in $\mathrm{CH}_{2} \mathrm{Cl}_{2}$ ) and $0.360 \mathrm{~mL}$ of tin(IV) chloride solution $(0.36 \mathrm{mmol}, 1.0 \mathrm{M}$ in $\left.\mathrm{CH}_{2} \mathrm{Cl}_{2}\right)$ to yield the product as an colorless oil $(0.027 \mathrm{~g}, 51 \%$ over 5 steps from loading of FMOCprotected (S)-prolinol 5): ${ }^{1} \mathrm{H}$ NMR (500 MHz, $\left.\mathrm{CDCl}_{3}\right) \delta 7.49$ (dd, $\left.J=8.5,1.7 \mathrm{~Hz}, 2 \mathrm{H}\right), 7.32-7.27$ (m, 2H), 7.08 (t, $J=7.5,7.5 \mathrm{~Hz}, 1 \mathrm{H}), 7.00$ (d, $J=7.6 \mathrm{~Hz}, 1 \mathrm{H}), 6.93$ (dd, $J=8.4,1.5 \mathrm{~Hz}, 2 \mathrm{H}), 4.79-4.73$ (m, 1H), 4.58 (dd, $J=17.7,2.3 \mathrm{~Hz}, 1 \mathrm{H}), 4.29$ (dd, $J=17.6,2.3 \mathrm{~Hz}, 1 \mathrm{H}), 4.15$ (dd, $J=13.8,7.6 \mathrm{~Hz}$, $1 \mathrm{H}$ ), 3.81 (s, 1H), 3.62 (d, $J=11.1 \mathrm{~Hz}, 1 \mathrm{H}$ ), 3.50 (dd, $J=10.9,9.2 \mathrm{~Hz}, 1 \mathrm{H}$ ), 3.31 (td, $J=14.8,7.2 \mathrm{~Hz}$, $1 \mathrm{H}), 3.22(\mathrm{td}, J=10.8,6.9 \mathrm{~Hz}, 1 \mathrm{H}), 2.70(\mathrm{qd}, J=13.4,6.7 \mathrm{~Hz}, 1 \mathrm{H}), 2.43(\mathrm{dd}, J=14.9,2.4 \mathrm{~Hz}, 1 \mathrm{H})$, 2.26 (dd, $J=14.8,6.4 \mathrm{~Hz}, 1 \mathrm{H}), 2.20$ (dd, $J=4.5,2.3 \mathrm{~Hz}, 1 \mathrm{H}), 1.90$ (td, $J=13.5,7.8 \mathrm{~Hz}, 1 \mathrm{H}), 1.72$ (t, $J=12.2,1 \mathrm{H}), 1.69-1.60(\mathrm{~m}, 1 \mathrm{H}), 1.45$ (dt, $J=12.6,6.3 \mathrm{~Hz}, 1 \mathrm{H}), 0.54(\mathrm{~d}, J=6.8 \mathrm{~Hz}, 3 \mathrm{H}), 0.45$ (s, $1 \mathrm{H}), 0.44(\mathrm{~s}, 1 \mathrm{H}) ;{ }^{13} \mathrm{C}$ NMR $\left(100 \mathrm{MHz}, \mathrm{CDCl}_{3}\right) \delta 177.2,171.7,160.6,141.4,135.3,129.1,128.9$, 127.7, 124.8, 122.7, 113.8, 109.1, 86.4, 81.1, 72.2, 67.4, 61.1, 54.9, 48.5, 46.8, 39.9, 38.9, 29.2, 28.2, 24.2, 14.9, -3.1, -3.9; ${ }^{29} \mathrm{Si}$ NMR (59 MHz, $\left.\mathrm{CDCl}_{3}\right) \delta-4.6$; IR 3391, 3295, 2956, 2874, 1721, 1606, 1591, $1446 \mathrm{~cm}^{-1}$; HRMS (TOF MS ES ${ }^{+}$m/z calcd for $\mathrm{C}_{31} \mathrm{H}_{39} \mathrm{~N}_{2} \mathrm{O}_{5} \mathrm{Si}(\mathrm{M}+\mathrm{H})^{+} 547.2628$, found 547.2609. 


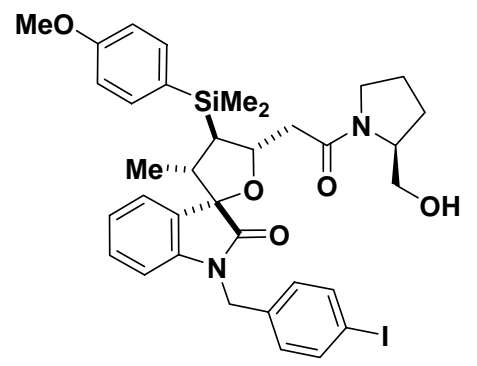

Spirocyclic annulation product amide-6j (13). The representative procedure for the Lewis acidmediated macrobead annulation and $\mathrm{Si}-\mathrm{O}$ cleavage was followed using $0.030 \mathrm{~g}$ of macrobeadsupported amido-crotylsilane $(R)-2(0.033 \mathrm{mmol}), N$-(4-iodobenzyl)isatin $5 \mathbf{j}(0.048 \mathrm{~g}, 0.132 \mathrm{mmol})$, $0.132 \mathrm{~mL}$ of DTBMP $\left(0.0 .066 \mathrm{mmol}, 0.5 \mathrm{M}\right.$ in $\left.\mathrm{CH}_{2} \mathrm{Cl}_{2}\right)$ and $0.132 \mathrm{~mL}$ of tin(IV) chloride solution (0.132 mmol, $1.0 \mathrm{M}$ in $\mathrm{CH}_{2} \mathrm{Cl}_{2}$ ) to yield the product as a pale yellow oil (3.2 $\mathrm{mg}, 16 \%$ over 5 steps from loading of FMOC-protected (S)-prolinol 5): ${ }^{1} \mathrm{H}$ NMR (600 MHz, $\left.\mathrm{CDCl}_{3}\right) \delta 7.62$ (d, $J=8.3 \mathrm{~Hz}$, 2H), $7.50(\mathrm{~d}, J=8.5 \mathrm{~Hz}, 2 \mathrm{H}), 7.31(\mathrm{~d}, J=7.2 \mathrm{~Hz}, 1 \mathrm{H}), 7.15(\mathrm{t}, J=7.2 \mathrm{~Hz}, 1 \mathrm{H}), 7.02(\mathrm{~m}, 3 \mathrm{H}), 6.94(\mathrm{~d}$, $J=8.5 \mathrm{~Hz}, 2 \mathrm{H}$ ), 6.61 (d, $J=7.8 \mathrm{~Hz}, 1 \mathrm{H}$ ), 5.27 (s, 1H), 4.93 (d, $J=15.8 \mathrm{~Hz}, 1 \mathrm{H}$ ), 4.78 (ddd, $J=11.4$, 6.3, $2.9 \mathrm{~Hz}, 1 \mathrm{H}), 4.61$ (d, $J=15.8 \mathrm{~Hz}, 1 \mathrm{H}), 4.17$ (dq, $J=7.8,1.8 \mathrm{~Hz}, 1 \mathrm{H}), 3.81(\mathrm{~s}, 3 \mathrm{H}), 3.63$ (dd, $J=$ 11.1, $2.1 \mathrm{~Hz}, 1 \mathrm{H}$ ), 3.50 (dd, $J=11.1,8.8 \mathrm{~Hz}, 1 \mathrm{H}$ ), 3.32 (td, $J=10.2,7.0 \mathrm{~Hz}, 1 \mathrm{H}$ ), 3.23 (td, $J=10.3$, $6.8 \mathrm{~Hz}, 1 \mathrm{H}), 2.77(\mathrm{qd}, J=13.6,6.8 \mathrm{~Hz}, 1 \mathrm{H}), 2.48(\mathrm{dd}, J=14.7,2.8 \mathrm{~Hz}, 1 \mathrm{H}), 2.28(\mathrm{dd}, J=14.7,6.4$ $\mathrm{Hz}, 1 \mathrm{H}), 1.91$ (qd, $J=15.0,7.5 \mathrm{~Hz}, 1 \mathrm{H}), 1.79(\mathrm{t}, J=12.2 \mathrm{~Hz}, 1 \mathrm{H}), 1.65$ (dq, $J=12.9,6.3 \mathrm{~Hz}, 2 \mathrm{H}$ ), 1.45 (td, $J=12.6,6.4 \mathrm{~Hz}, 1 \mathrm{H}), 0.56(\mathrm{~d}, J=6.8 \mathrm{~Hz}, 3 \mathrm{H}), 0.465$ (s, 3H), $0.455(\mathrm{~s}, 3 \mathrm{H}) ;{ }^{13} \mathrm{C}$ NMR $(100$ $\left.\mathrm{MHz}, \mathrm{CDCl}_{3}\right) \delta$ 7.62 192.8, 178.2, 171.7, 160.7, 142.2, 137.8, 135.6, 135.3, 129.2, 129.1, 127.8, 125.1, 122.6, 113.8, 108.9, 93.0, 86.3, 81.3, 67.5, 61.2, 55.0, 48.5, 46.6, 43.4, 39.8, 38.9, 28.2, 24.2, 15.0, 3.1, -3.7; HRMS (TOF MS ES ${ }^{+}$) $m / z$ calcd for $\mathrm{C}_{35} \mathrm{H}_{42} \mathrm{IN}_{2} \mathrm{O}_{5} \mathrm{Si}(\mathrm{M}+\mathrm{H})^{+}$725.1908, found 725.1907.

\section{Representative aryl amide products from solid phase amidation:}

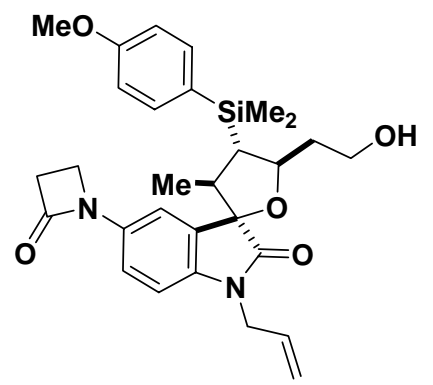

Spirocycle 8. Representative Procedure for Solid Phase Aryl Amidation. The procedure and characterization details are provided for the synthesis of aryl amide (S)-8 from aryl iodide (S)-7a. The same procedure was followed using aryl iodide $(R)$-7a to afford aryl amide $(R)$-8. The macrobeadsupported spiroxindole (S)-7a (loose macrobeads or in X-kans) was added to a vial or flask equipped with a rubber septa. Then copper (I) iodide (0.1 equiv), azetidinone (10 equiv) and $\mathrm{Cs}_{2} \mathrm{CO}_{3}$ (2 equiv) were added and the flask was evacuated and backfilled $(3 \times 10$ s) with argon. Then DMF was added, sufficient to cover the resin or X-kans, followed by $N, N^{\prime}$-dimethylethylenediamine (5 equiv). The vial was layered with argon $(1 \times 10 \mathrm{~s})$ and the reaction mixture was shaken at $23^{\circ} \mathrm{C}$ for $24-48 \mathrm{~h}$. The reaction mixture was quenched by dilution with EtOAc. The solution was then drained and the resin was washed with the following protocol: THF ( $2 \times 15 \mathrm{~min}), 0.2 \mathrm{M}$ sodium diethyldithio carbamate 
trihydrate (DETC) in THF/ $\mathrm{H}_{2} \mathrm{O}$ (3:1 ratio, approximately $6 \times 15 \mathrm{~min}$ until the solution is colorless), $\mathrm{THF} / \mathrm{H}_{2} \mathrm{O}$ (3:1 ratio, $2 \times 15 \mathrm{~min}$ ), THF ( 3 x $15 \mathrm{~min}$ ), $\mathrm{MeCN}$ (3 x $15 \mathrm{~min}$ ), and $\mathrm{CH}_{2} \mathrm{Cl}_{2}$ (3 x $15 \mathrm{~min}$ ). $\mathrm{HF} / \mathrm{py}$ cleavage procedure for a single $\mathrm{X}$-kan $(0.030 \mathrm{~g}, 0.033 \mathrm{mmol}$ of resin), followed by purification using flash chromatography (EtOAc/ $\left.\mathrm{CH}_{2} \mathrm{Cl}_{2}\right)$, yielded the product as a colorless oil $(0.019 \mathrm{~g}, 78 \%$ over 4 steps from crotylsilane 3a): ${ }^{1} \mathrm{H}$ NMR $\left(600 \mathrm{MHz}, \mathrm{CDCl}_{3}\right) \delta 7.53(\mathrm{~d}, J=1.6 \mathrm{~Hz}, 1 \mathrm{H}), 7.45(\mathrm{~d}, J=$ $8.6 \mathrm{~Hz}, 2 \mathrm{H}), 7.03$ (dd, $J=8.3,1.9 \mathrm{~Hz}, 1 \mathrm{H}), 6.92(\mathrm{~d}, J=8.5 \mathrm{~Hz}, 2 \mathrm{H}), 6.73(\mathrm{~d}, J=8.3 \mathrm{~Hz}, 1 \mathrm{H}), 5.79$ (tdd, $J=15.7,10.4,5.3 \mathrm{~Hz}, 1 \mathrm{H}), 5.22-5.15(\mathrm{~m}, 2 \mathrm{H}), 4.54$ (td, $J=11.2,5.6 \mathrm{~Hz}, 1 \mathrm{H}), 4.41$ (ddd, $J=$ 16.7, 5.2, $1.7 \mathrm{~Hz}, 1 \mathrm{H}$ ), 4.14 (ddd, $J=16.4,5.4,1.4 \mathrm{~Hz}, 1 \mathrm{H}$ ), 3.81 (s, 3H), 3.74 (td, $J=11.2,5.8 \mathrm{~Hz}$, $1 \mathrm{H}), 3.65(\mathrm{t}, J=4.4 \mathrm{~Hz}, 1 \mathrm{H}), 3.62(\mathrm{t}, J=4.3 \mathrm{~Hz}, 2 \mathrm{H}), 3.12(\mathrm{t}, J=4.3 \mathrm{~Hz}, 2 \mathrm{H}), 2.70(\mathrm{qd}, J=13.6,6.8$ Hz, 1H), 2.45 (bs, 1H), 1.69 (q, $J=5.7 \mathrm{~Hz}, 2 \mathrm{H}), 1.57$ (t, $J=12.0 \mathrm{~Hz}, 1 \mathrm{H}), 0.55$ (d, $J=6.8 \mathrm{~Hz}, 3 \mathrm{H}$ ), 0.414 (s, 3H), 0.408 (s, 3H); ${ }^{13} \mathrm{C}$ NMR $\left(100 \mathrm{MHz}, \mathrm{CDCl}_{3}\right) \delta 177.4,164.0,160.7,138.6,135.2,134.2$, 131.2, 130.2, 127.5, 117.6, 115.8, 114.4, 113.8, 109.3, 86.7, 84.9, 60.9, 54.9, 46.4, 42.5, 40.2, 38.2, 38.0, 36.1, 14.8, -3.2, -3.4; HRMS (TOF MS ES ${ }^{+}$m/z calcd for $\mathrm{C}_{29} \mathrm{H}_{40} \mathrm{~N}_{3} \mathrm{O}_{5} \mathrm{Si}\left(\mathrm{M}+\mathrm{NH}_{4}\right)^{+}$538.2737, found 538.2753 .
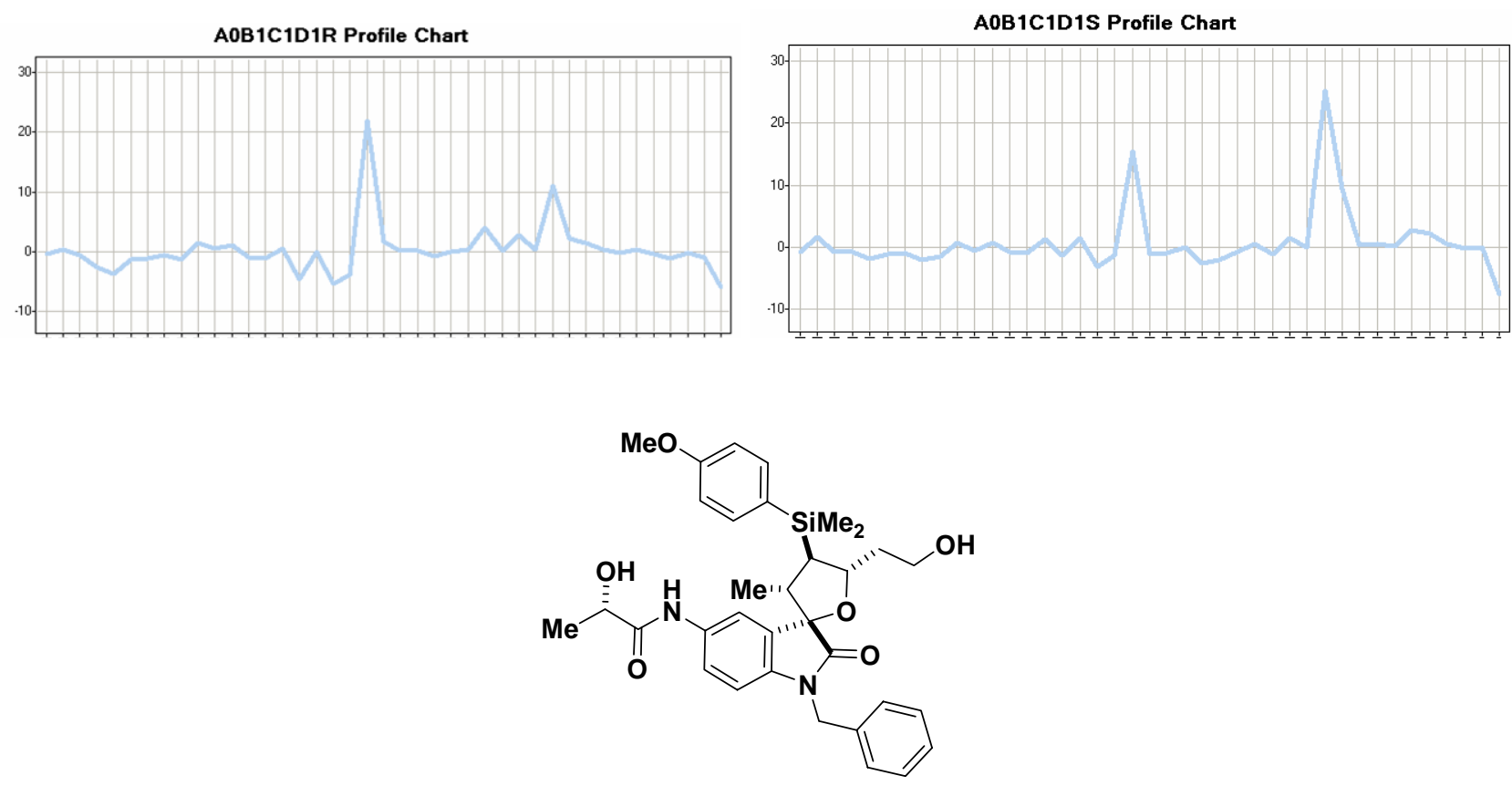

Spirocycle 10. The representative procedure for solid phase aryl amidation was followed using macrobead-supported spirocycle hydroxyl $(R)$-6k and $(S)$-lactamide. HF/py cleavage procedure for a single $\mathrm{X}$-kan $(0.030 \mathrm{~g}, 0.033 \mathrm{mmol}$ of resin), followed by purification using flash chromatography ( $\mathrm{EtOAc} / \mathrm{CH}_{2} \mathrm{Cl}_{2}$ ), yielded the product as a colorless oil $(0.015 \mathrm{~g}, 77 \%$ over four steps from crotylsilane 3a): ${ }^{1} \mathrm{H}$ NMR (600 MHz, CDCl $) \delta 8.74$ (bs, $1 \mathrm{H}$ ), 7.43 (d, $J=8.5 \mathrm{~Hz}, 2 \mathrm{H}$ ), 7.39 (dd, $J=8.5,1.8 \mathrm{~Hz}$, 1H), 7.29 (t, $J=7.3 \mathrm{~Hz}, 2 \mathrm{H}), 7.25$ (d, $J=7.4 \mathrm{~Hz}, 1 \mathrm{H}), 7.21$ (d, $J=7.2 \mathrm{~Hz}, 2 \mathrm{H}), 7.18$ (s, 1H), 6.93 (d, $J=8.5 \mathrm{~Hz}, 2 \mathrm{H}), 6.47$ (d, $J=8.5 \mathrm{~Hz}, 1 \mathrm{H}), 5.03(\mathrm{~d}, J=15.7 \mathrm{~Hz}, 1 \mathrm{H}), 4.54(\mathrm{~d}, J=15.9 \mathrm{~Hz}, 1 \mathrm{H}), 4.53$ (dd, $J=20.4,2.0 \mathrm{~Hz}, 1 \mathrm{H}$ ), 4.32 (q, $J=6.7 \mathrm{~Hz}, 1 \mathrm{H}$ ), 4.15 (bs, $1 \mathrm{H}$ ), 3.81 (s, 3H), 3.74 (t, $J=5.3 \mathrm{~Hz}$, 2H), 3.14 (bs, $1 \mathrm{H}$ ), 2.72 (qd, $J=13.6,6.8 \mathrm{~Hz}, 1 \mathrm{H}), 1.72$ (td, $J=11.5,6.3 \mathrm{~Hz}, 1 \mathrm{H}), 1.64$ (td, $J=14.7$, $5.5 \mathrm{~Hz}, 1 \mathrm{H}), 1.45$ (d, $J=7.0 \mathrm{~Hz}, 3 \mathrm{H}), 1.41$ (d, $J=12.5 \mathrm{~Hz}, 1 \mathrm{H}), 0.51$ (d, $J=6.8 \mathrm{~Hz}, 3 \mathrm{H}), 0.41(\mathrm{~s}, 6 \mathrm{H})$; ${ }^{13} \mathrm{C}$ NMR $\left(100 \mathrm{MHz}, \mathrm{CDCl}_{3}\right) \delta 179.1,172.7,160.7,138.4,135.3,135.2,132.7,129.2,128.8,127.7$, 127.3, 127.0, 120.6, 117.4, 113.9, 109.6, 87.0, 84.5, 69.0, 60.8, 55.0, 47.0, 44.1, 40.6, 38.4, 20.6, 14.9, -3.0, -3.6; HRMS (TOF MS ES ${ }^{+}$) m/z calcd for $\mathrm{C}_{33} \mathrm{H}_{41} \mathrm{~N}_{2} \mathrm{O}_{6} \mathrm{Si}(\mathrm{M}+\mathrm{H})^{+} 589.2734$, found 589.2738. 

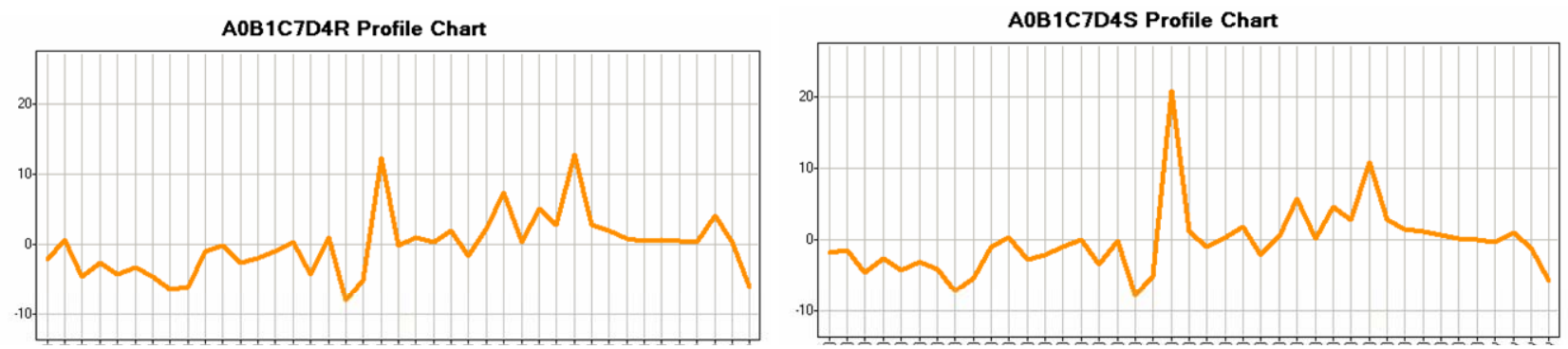

\section{Growth Inhibition Assays for Spirocycles (S)-12 and (R)-13}

Secondary screening was performed in triplicate to retest active compounds and demonstrate dosedependent activity. $\mathrm{EC}_{50}$ values were obtained for representative compounds, and are shown for spirocycles $(S)-\mathbf{1 2}$ and $(R)-\mathbf{1 3}$. Compounds were prepared as DMSO solutions and screened in 384well plates in triplicate assay experiments with a 1:3 dilution. For negative controls, one 384-well plate of baseline "mock-treatment" controls (DMSO) was performed for each replicate, in addition to DMSO-only control wells that were incorporated into each compounds assay plate. Examples are shown for the growth inhibition of A549 human non-small cell lung carcinoma cells and HepG2 human hepatocellular carcinoma cells using a CellTiter-Blue ${ }^{\circledR}$ cell viability assay (Promega, Madison, WI) to estimate the number of viable cells present in multiwell plates. The CellTiter-Blue ${ }^{\circledR}$ reagent contains a fluorogenic, membrane-permeant redox dye (resazurin) that is converted to fluorescent end product (resorufin) upon reduction by intracellular reducing agents (primarily NADH). The resultant fluorescence (535Ex/595Em) is correlated to the ability of metabolically active, viable cells to reduce resazurin into fluorescent resorufin. Nonviable cells rapidly lose metabolic capacity, do not reduce the indicator dye, and thus do not generate a fluorescent signal.

A549 Cell Viability Assay. A549 human non-small cell lung carcinoma cells were cultured in a humidified environment with $5 \% \mathrm{CO}_{2}$ at $37{ }^{\circ} \mathrm{C}$ (standard tissue culture techniques) in Dulbecco's modified Eagle medium (DMEM) containing $10 \%$ fetal bovine serum (FBS), $2 \mathrm{mM}$ L-glutamine, 100 units $/ \mathrm{mL}$ penicillin, and $1 \mathrm{mg} / \mathrm{mL}$ streptomycin. The assay was initiated by plating 5000 cells/well (50 $\mu \mathrm{L} /$ well of medium) into black 384-well clear bottom plates (Nunc) using an automated plate filler (Wellmate 384 liquid handler) and allowing the cells to adhere for 24 hrs. After 24 hrs of growth, the medium was replaced with $25 \mathrm{uL}$ of medium with $0.5 \%$ FBS and aliquots of $300 \mathrm{~nL}$ of compound stock solutions in DMSO (a 1:3 dilution in a seven-point dose curve) were transferred from the compound plate to each well of the assay plate using an automated pin-based compound transfer robot (CyBio CyBi ${ }^{\mathrm{TM}}$-Well) equipped with a 384-member non-slotted, floating pin array (V \& P scientific). Cells were incubated with compounds for $24 \mathrm{~h}$. Intracellular reducing agents, roughly correlated with cell viability, was determined using the CellTiter-Blue ${ }^{\circledR}$ reagent (Promega, Madison, WI) according to the manufacture's instructions. Following incubation of cells with compounds, $17 \mu \mathrm{L}$ of a solution of CellTiter-Blue ${ }^{\circledR}$ reagent (diluted 1:6 in PBS) was then added to cells. Cells were incubated at $37^{\circ} \mathrm{C}$ for $4 \mathrm{~h}$, and $10 \mu \mathrm{L}$ of $3 \%$ SDS was added before fluorescence detection. The fluorescence (535Ex/595Em) from each plate was recorded using an automated plate reader (Perkin-Elmer Envision 1). 


\section{A549 Growth Inhibition}

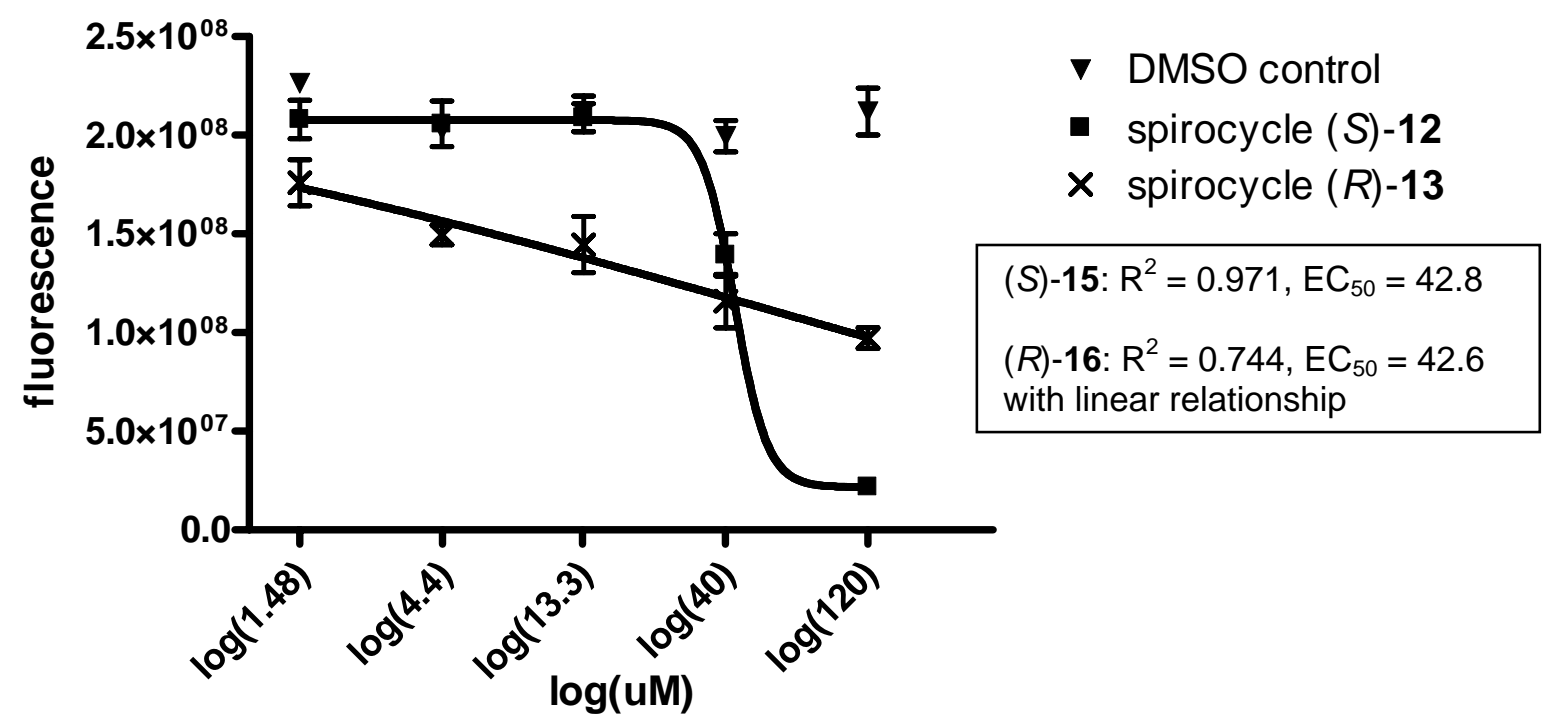

Figure S-3. Growth inhibition of A549 cells by spirocycles $(S)-\mathbf{1 2}$ and $(R)-\mathbf{1 3}$, as determined using fluorescence detection (535Ex/595Em) with the CellTiter-Blue ${ }^{\circledR}$ reagent. Compounds were screened as a 1:3 dilution, starting with a concentration of $120 \mu \mathrm{M}$. Data was analyzed with non-linear regression (curve fit) and parameters for sigmoidal dose response (variable slope) using GraphPad Prism software.

HepG2 Cell Viability Assay. HepG2 human hepatocellular carcinoma cells were cultured in a humidified environment with $5 \% \mathrm{CO}_{2}$ at $37{ }^{\circ} \mathrm{C}$ (standard tissue culture techniques) in minimum essential medium (Eagle) containing $10 \%$ fetal bovine serum (FBS), 2 mM L-glutamine, 100 units/mL penicillin, and $1 \mathrm{mg} / \mathrm{mL}$ streptomycin. The assay was initiated by plating 4000 cells/well (50 $\mu \mathrm{L} /$ well of medium) into black 384-well clear bottom plates (Nunc) using an automated plate filler (Wellmate 384 liquid handler) and allowing the cells to adhere for $24 \mathrm{~h}$. After $24 \mathrm{~h}$ of growth, the medium was replaced with $25 \mathrm{uL}$ of medium with $0.5 \% \mathrm{FBS}$ and aliquots of $300 \mathrm{~nL}$ of compound stock solutions in DMSO (a 1:3 dilution in a seven-point dose curve) were transferred from the compound plate to each well of the assay plate using an automated pin-based compound transfer robot (CyBio $\mathrm{CyBi}^{\mathrm{TM}}$-Well) equipped with a 384-member non-slotted, floating pin array (V \& P scientific). Cells were incubated with compounds for $24 \mathrm{~h}$. Intracellular reducing agents (cell viability) was determined using the CellTiter-Blue $^{\circledR}$ reagent (Promega, Madison, WI) according to the manufacture's instructions. Following incubation of cells with compounds, $17 \mu \mathrm{L}$ of a dilute solution of CellTiter-Blue ${ }^{\circledR}$ reagent (1:6 in PBS) was then added to cells. Cells were incubated at $37^{\circ} \mathrm{C}$ for $4 \mathrm{~h}$, and $10 \mu \mathrm{L}$ of $3 \%$ SDS was added before fluorescence detection. The fluorescence (535Ex/595Em) from each plate was recorded using an automated plate reader (Perkin-Elmer Envision 1). 


\section{HepG2 Growth Inhibition}

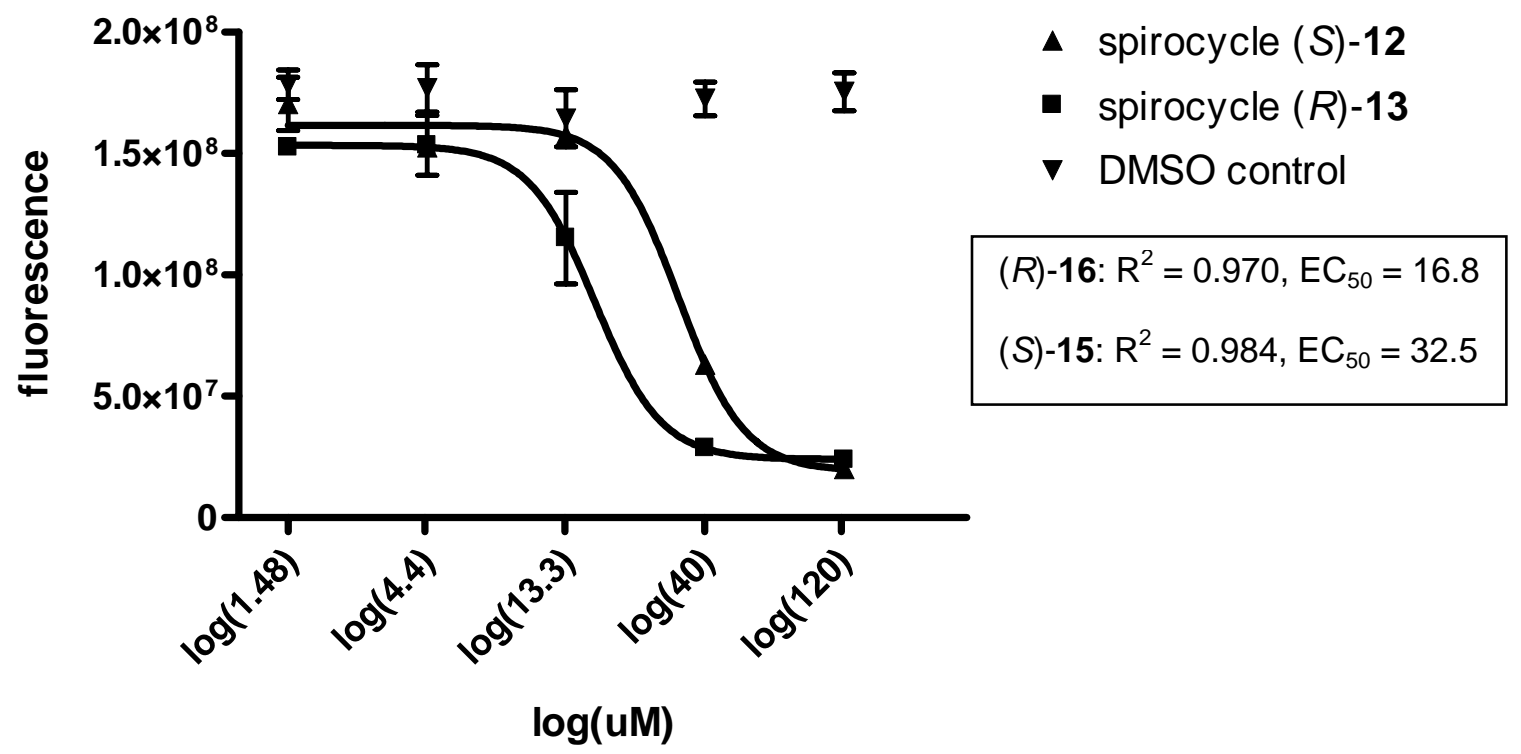

Figure S-4. Growth inhibition of HepG2 cells by spirocycles $(S)-\mathbf{1 2}$ and $(R)-\mathbf{1 3}$, as determined using fluorescence detection (535Ex/595Em) with the CellTiter-Blue ${ }^{\circledR}$ reagent. Compounds were screened as a 1:3 dilution, starting with a concentration of $120 \mu \mathrm{M}$. Data was analyzed with non-linear regression (curve fit) and parameters for sigmoidal dose response (variable slope) using GraphPad Prism software.

\footnotetext{
${ }^{1}$ The di-isopropylsilyl linker used for this work was developed previously in our lab: a) J. A. Tallarico, K. M. Depew, H. E. Pelish, N. J. Westwood, C. W. Lindsley, M. D. Shair, S. L. Schreiber, M. A. Foley J. Comb. Chem. 2001, 3, 312-318.

${ }^{2}$ For a detailed description of data analysis and error-modeling methods for multidimensional screening, see: (a) Kim, Y.-K.; Arai, M. A.; Arai, T.; Lamenzo, J. O.; Dean, E. F. III; Patterson, N.; Clemons, P. A., Schreiber, S. L., J. Am. Chem. Soc., 2004, 126, 14740-14745; (b) Kelly, et al Mol. Imaging 2006; (c) http://chembank.broad.harvard.edu/help.htm ; (d) Clemons, P. A. unpublished. ${ }^{3}$ Clemons, P. A.; Koehler, A. N.; Wagner, B. K.; Sprigings, T. G.; Spring, D. R.; King, R. W.; Schreiber, S. L.; Foley, M. A., Chem. Biol. 2001, 8, 1183-1195.

${ }^{4}$ Bevington, P. R. and Robinson, D. K. Data Reduction and Error Analysis for the Physical Sciences (McGraw-Hill, Boston, MA, 1991).

5 (a) Gunter, B., Brideau, C., Pikounis, B., Liaw, A. J. Biomol. Screen. 2003, 8, 624-633. (b) Lundholt, B. K., Scudder, K. M., Pagliaro, L. J. Biomol. Screen. 2003, 8, 566-570.

${ }^{6}$ Beresis, R. T.; Solomon, J. S.; Yang, M. G.; Jain, N. F.; Panek, J. S. Org Syn 1998, 75, 78-88.
} 


\section{X-ray Data for Spirocycle Ester-6l}

\section{Experimental Section:}

Data was obtained for crystals of spirocycle ester-61, which is also referred to in this text as sls97t. A colorless thin plate crystal with dimensions $0.10 \times 0.04 \times 0.04 \mathrm{~mm}$ was mounted on a nylon loop using very small amount of paratone oil. Data were collected using a Bruker SMART CCD (charge coupled device) based diffractometer equipped with an Oxford Cryostream low-temperature apparatus operating at $193 \mathrm{~K}$. Data were measured using omega scans of $0.3^{\circ}$ per frame for 30 seconds, such that a hemisphere was collected. A total of 1271 frames were collected with a maximum resolution of $0.76 \AA$. The first 50 frames were recollected at the end of data collection to monitor for decay. Cell parameters were retrieved using SMART ${ }^{1}$ software and refined using SAINT on all observed reflections. Data reduction was performed using the SAINT software ${ }^{2}$ which corrects for Lp and decay. Absorption corrections were applied using SADABS ${ }^{6}$ multiscan technique, supplied by George Sheldrick. The structures are solved by the direct method using the SHELXS- $97^{3}$ program and refined by least squares method on $\mathrm{F}^{2}$, SHELXL-97, ${ }^{4}$ incorporated in SHELXTL-PC V $6.10 .{ }^{5}$

The structure was solved in the space group $\mathrm{P} 1$ (\# 2) by analysis of systematic absences. All non-hydrogen atoms are refined anisotropically. Hydrogens were calculated by geometrical methods and refined as a riding model. The crystal showed signs that it may have rotational twinning. Attempts to sort out the rotational twin and defining the properties of the twin proved to cause the statistics to be worse than treating the data as non-twinned. The crystal used for the diffraction study showed no decomposition during data collection. All drawing are done at 50\% ellipsoids.

Acknowledgement. The CCD based x-ray diffractometer at Harvard University was purchased through NIH grant (1S10RR11937-01).

\section{References}

1. SMART V 5.625 (NT) Software for the CCD Detector System; Bruker Analytical X-ray Systems, Madison, WI (2001).

2. SAINT V 6.22 (NT) Software for the CCD Detector System Bruker Analytical X-ray Systems, Madison, WI (2001).

3. Sheldrick, G. M. SHELXS-90, Program for the Solution of Crystal Structure, University of Göttingen, Germany, 1990.

4. Sheldrick, G. M. SHELXL-97, Program for the Refinement of Crystal Structure, University of Göttingen, Germany, 1997.

5. SHELXTL 6.1 (PC-Version), Program library for Structure Solution and Molecular Graphics; Bruker Analytical X-ray Systems, Madison, WI (2000).

6. SADABS. Program for absorption corrections using Siemens CCD based on the method of Robert Blessing; Blessing, R.H. Acta Cryst. A51 1995, 33-38.

\footnotetext{
${ }^{a}$ Obtained with graphite monochromated $\mathrm{Mo} \mathrm{K \alpha}(\lambda=0.71073 \AA)$ radiation.
}

${ }^{\mathrm{b}} R 1=\sum|| F_{\mathrm{o}}|-| F_{\mathrm{c}}|| / \sum\left|F_{\mathrm{o}}\right| .{ }^{\mathrm{c}} w R_{2}=\left\{\sum\left[w\left(F_{\mathrm{o}}{ }^{2}-F_{\mathrm{c}}{ }^{2}\right)^{2} /\left\{\sum\left[w\left(F_{\mathrm{o}}{ }^{2}\right)^{2}\right]\right\}^{1 / 2}\right.\right.$. 
The following are $50 \%$ thermal ellipsoidal drawings of the molecule in the asymmetric cell with various amount of labeling.
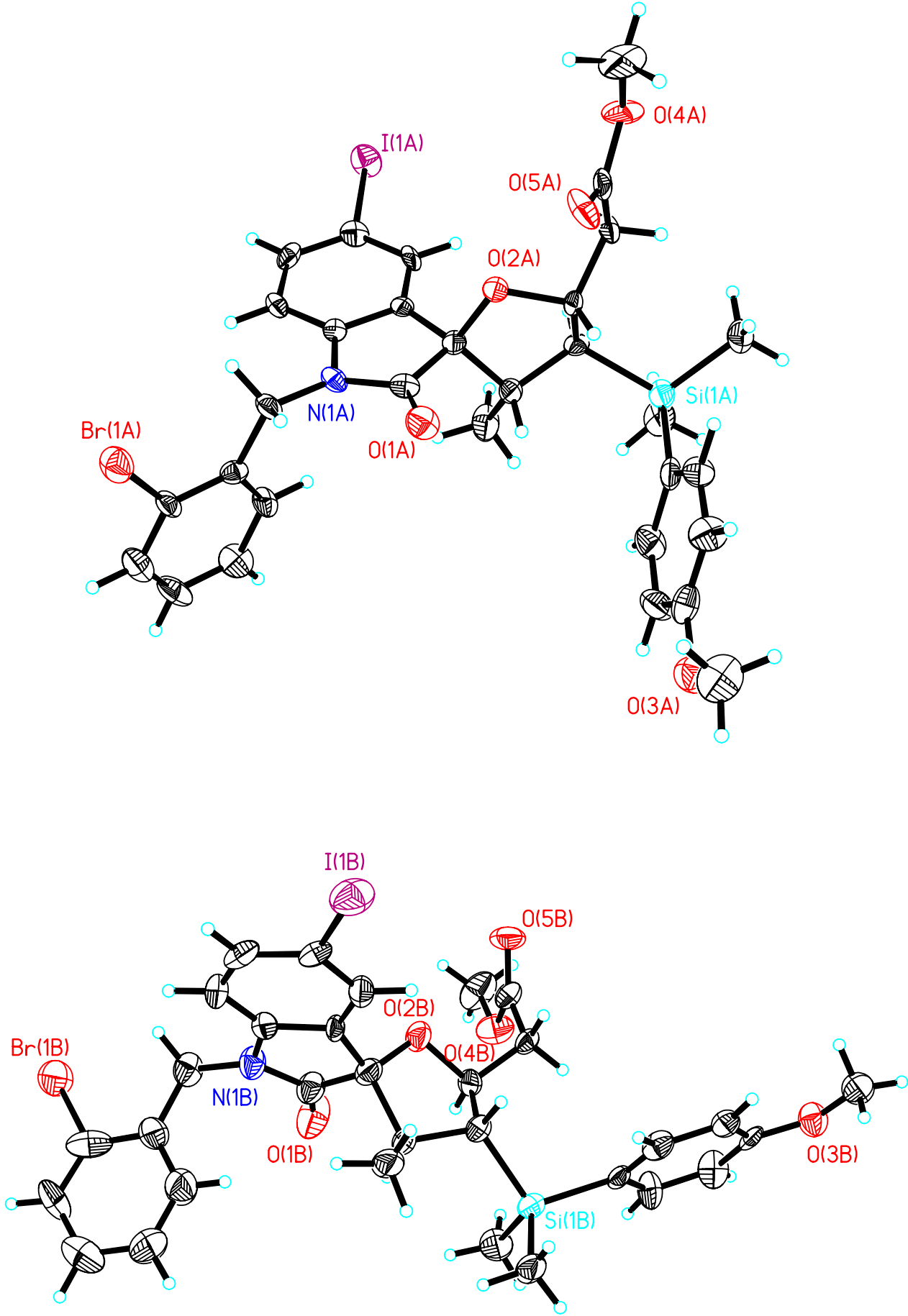
Table S-2. Crystal data and structure refinement for sls97t.

Identification code

Empirical formula

Formula weight

Temperature

Wavelength

Crystal system

Space group

Unit cell dimensions

Volume

$\mathrm{Z}$

Density (calculated)

Absorption coefficient

$\mathrm{F}(000)$

Crystal size

Theta range for data collection

Index ranges

Reflections collected

Independent reflections

Completeness to theta $=25.00^{\circ}$

Absorption correction

Max. and min. transmission

Refinement method

Data / restraints / parameters

Goodness-of-fit on $\mathrm{F}^{2}$

Final R indices [I $>2 \operatorname{sigma}(\mathrm{I})]$

$\mathrm{R}$ indices (all data)

Largest diff. peak and hole sls97t

C31 H33 Br I N O5 Si

734.48

193(2) K

$0.71073 \AA$

Triclinic

P-1

$\mathrm{a}=11.094(6) \AA \quad \alpha=81.701(8)^{\circ}$.

$\mathrm{b}=11.378(6) \AA \quad \beta=79.045(8)^{\circ}$.

$\mathrm{c}=25.409(13) \AA \quad \gamma=82.545(8)^{\circ}$.

3098(3) $\AA^{3}$

4

$1.574 \mathrm{Mg} / \mathrm{m}^{3}$

$2.401 \mathrm{~mm}^{-1}$

1472

$0.10 \times 0.04 \times 0.04 \mathrm{~mm}^{3}$

1.65 to $25.00^{\circ}$.

$-13<=\mathrm{h}<=10,-13<=\mathrm{k}<=13,-29<=\mathrm{l}<=30$

17009

$10826[\mathrm{R}$ (int) $=0.0871]$

$99.2 \%$

Empirical

0.9101 and 0.7952

Full-matrix least-squares on $\mathrm{F}^{2}$

10826 / 0 / 732

0.955

$\mathrm{R} 1=0.0736, \mathrm{wR} 2=0.1439$

$\mathrm{R} 1=0.1410, \mathrm{wR} 2=0.1655$

1.599 and -1.253 e. $\AA^{-3}$ 

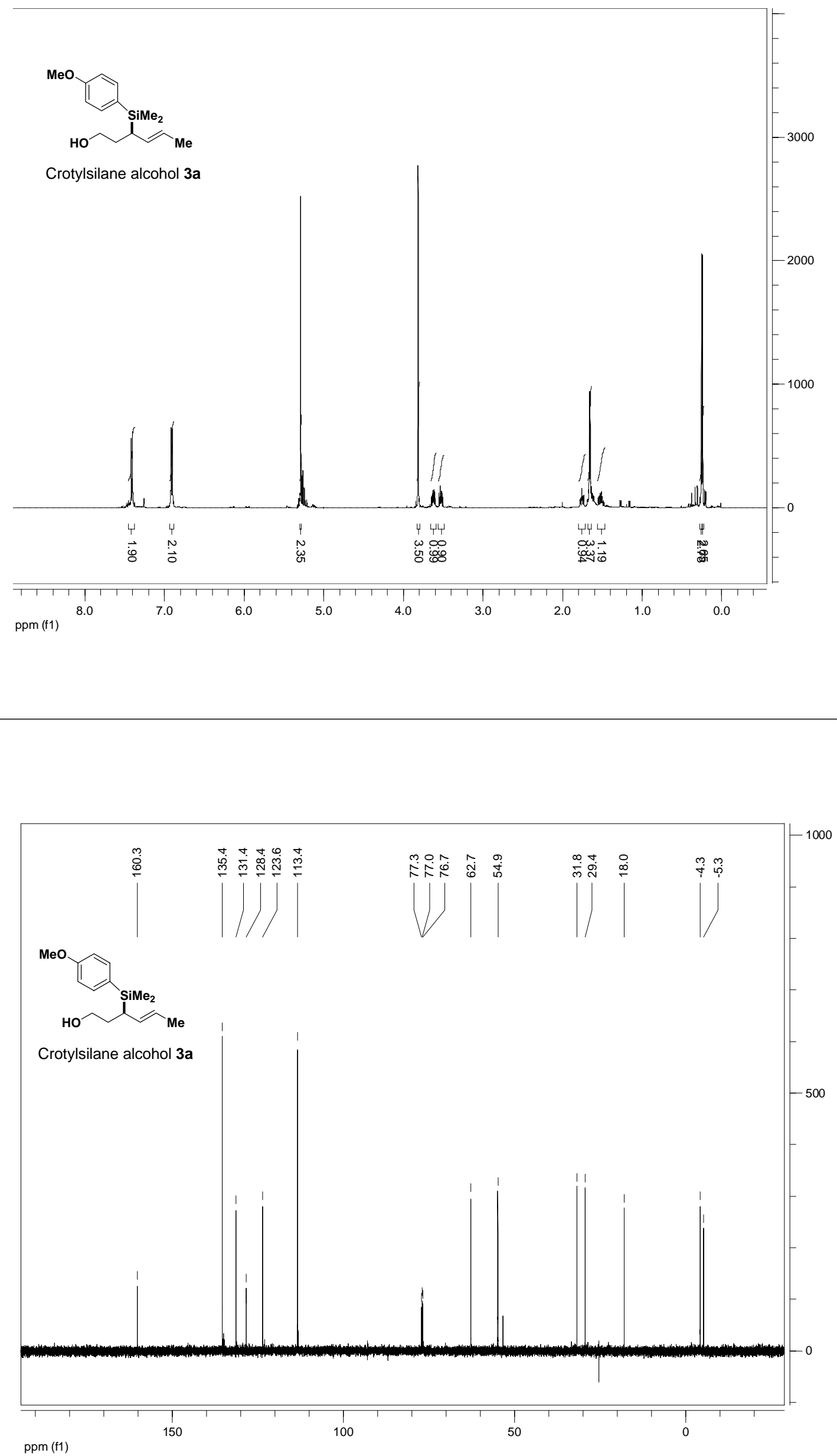

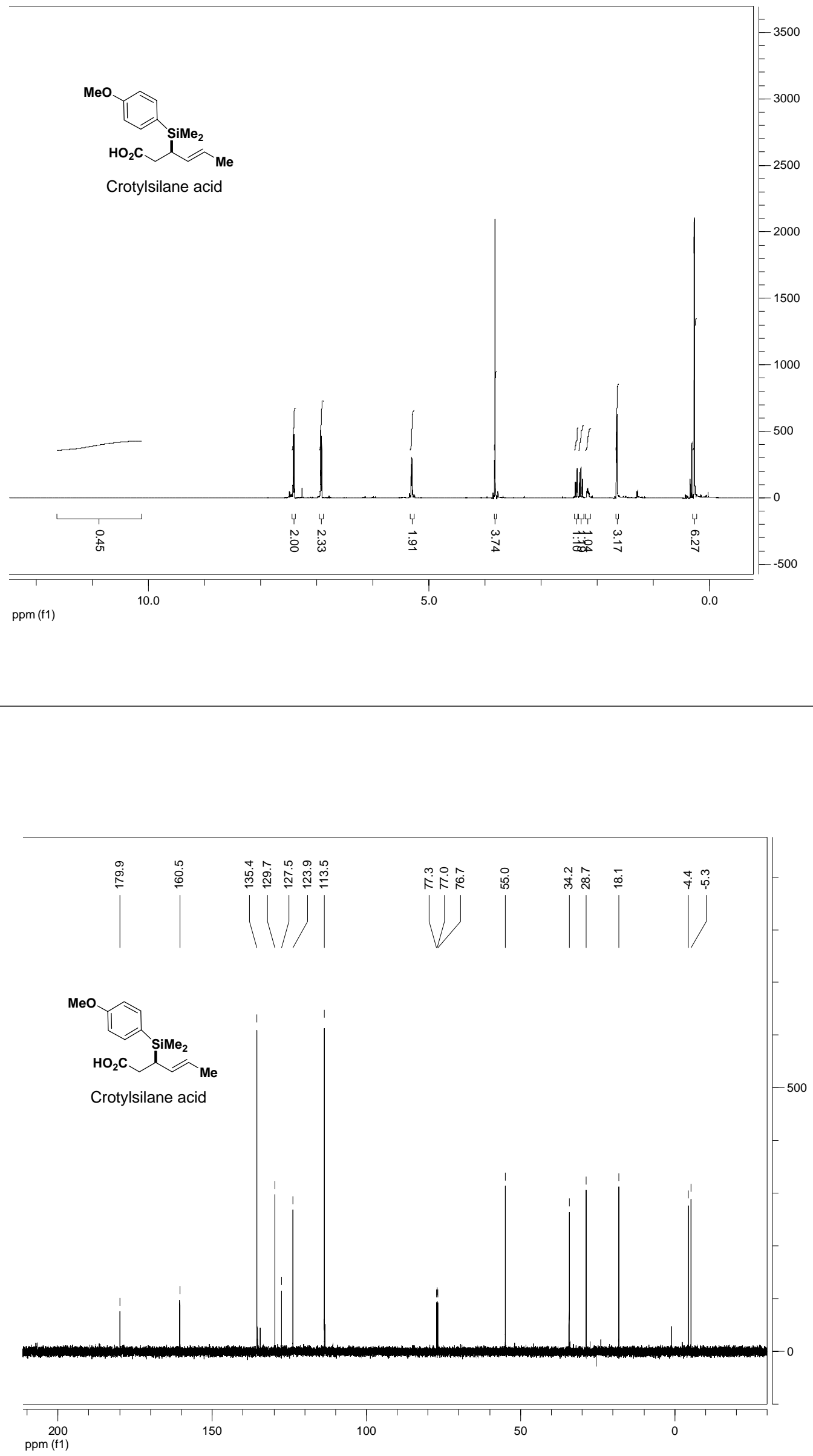


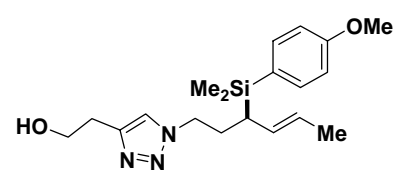

Triazole crotylsilane 4
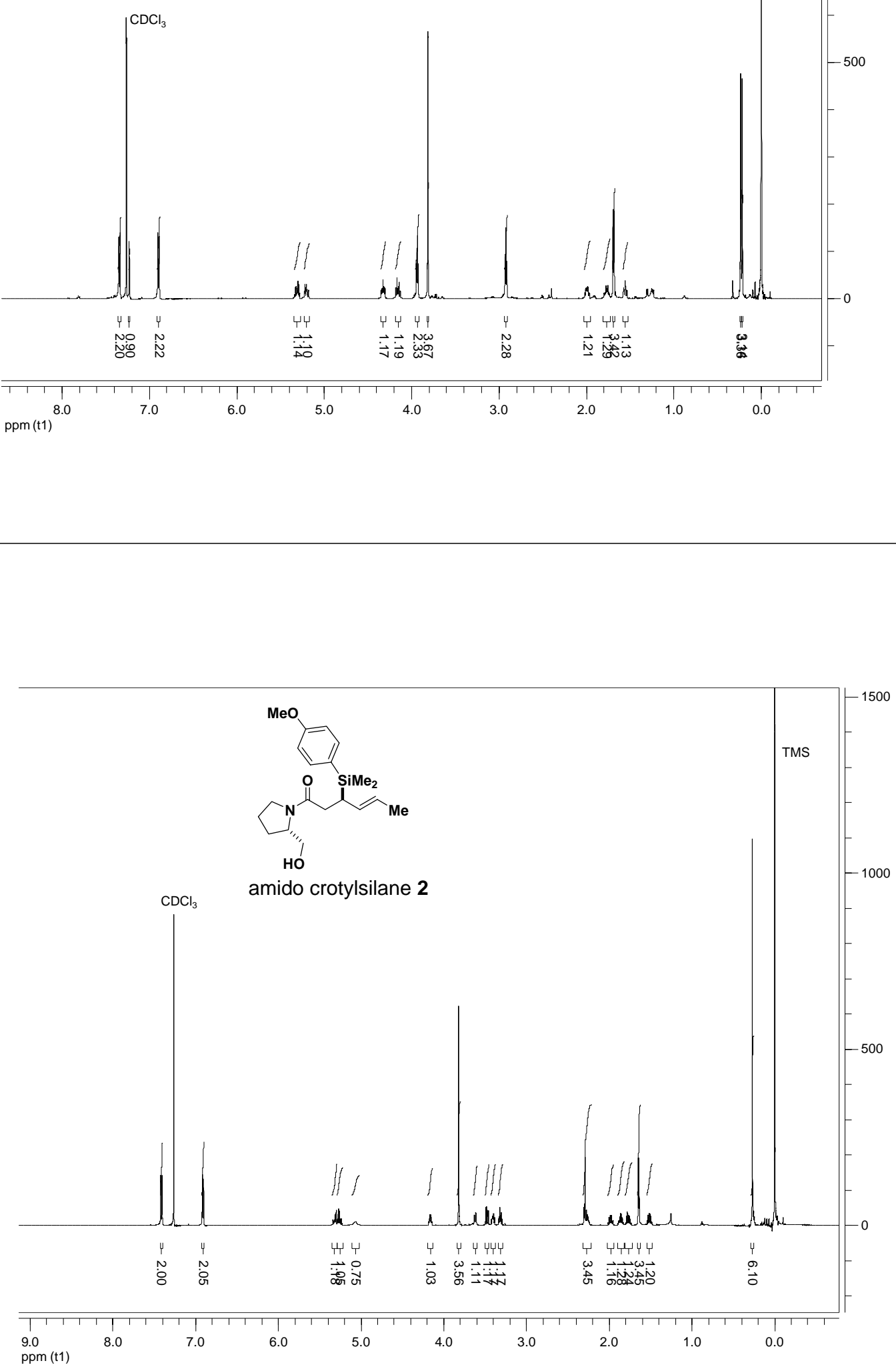

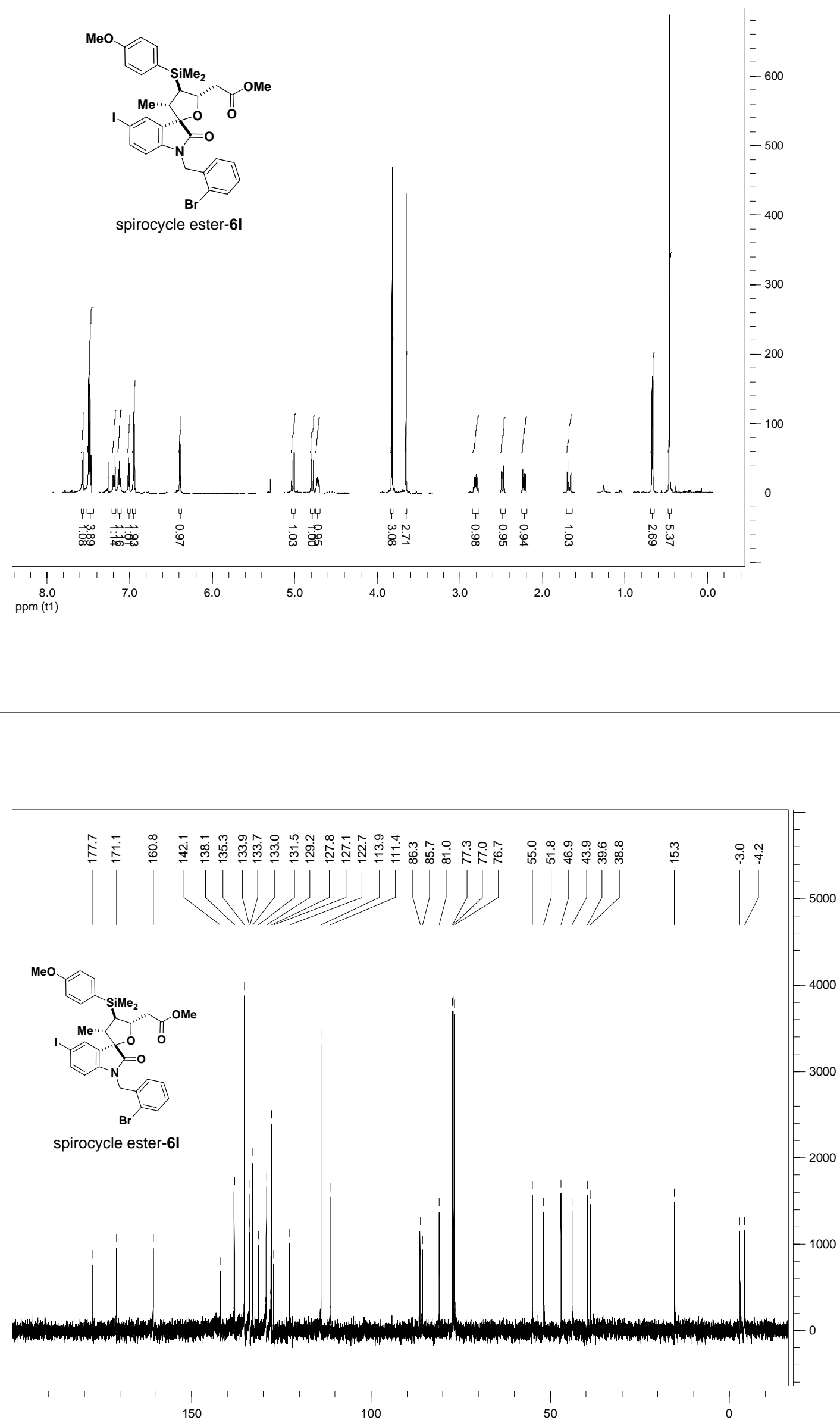

ppm (f1) 

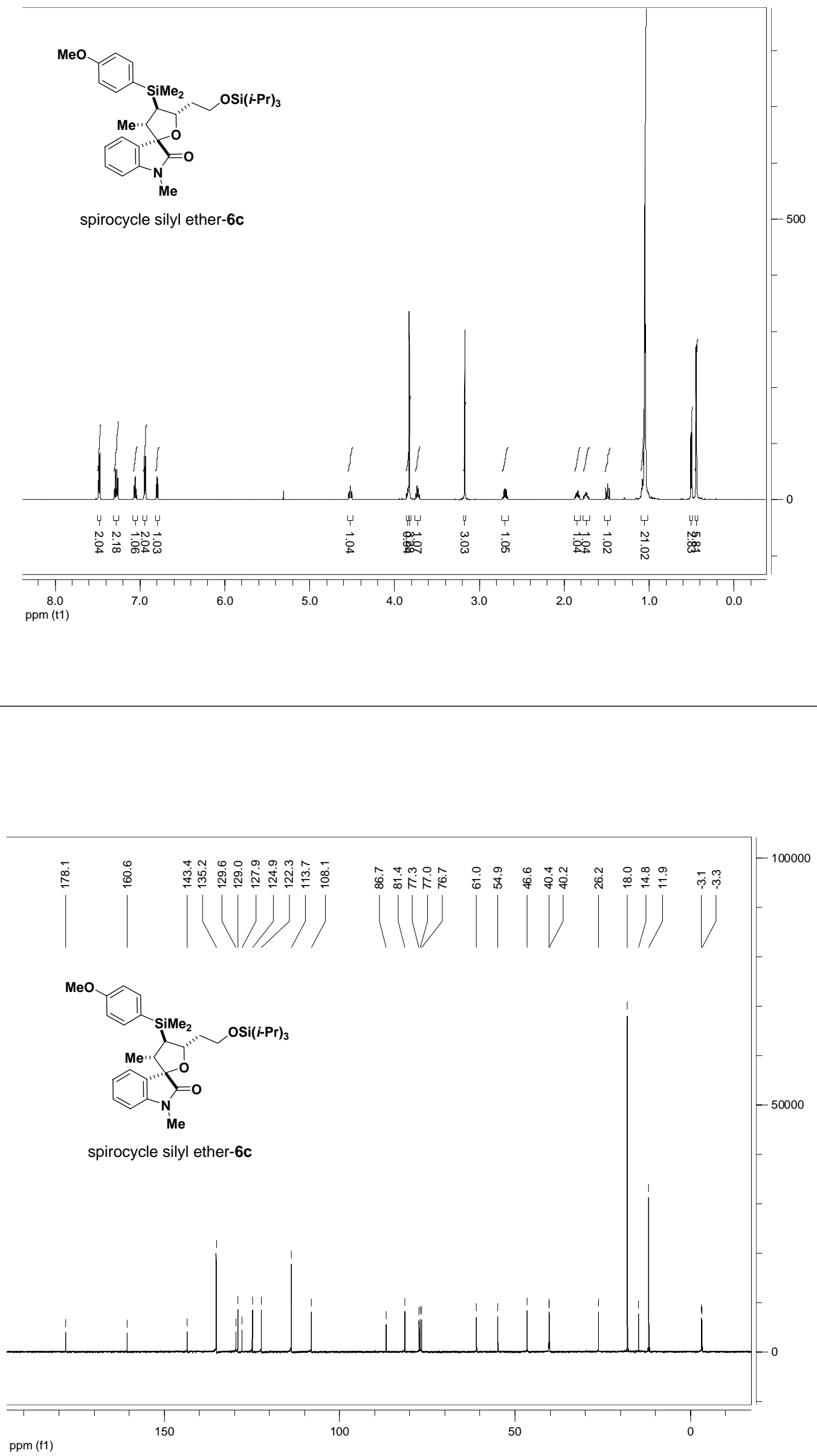

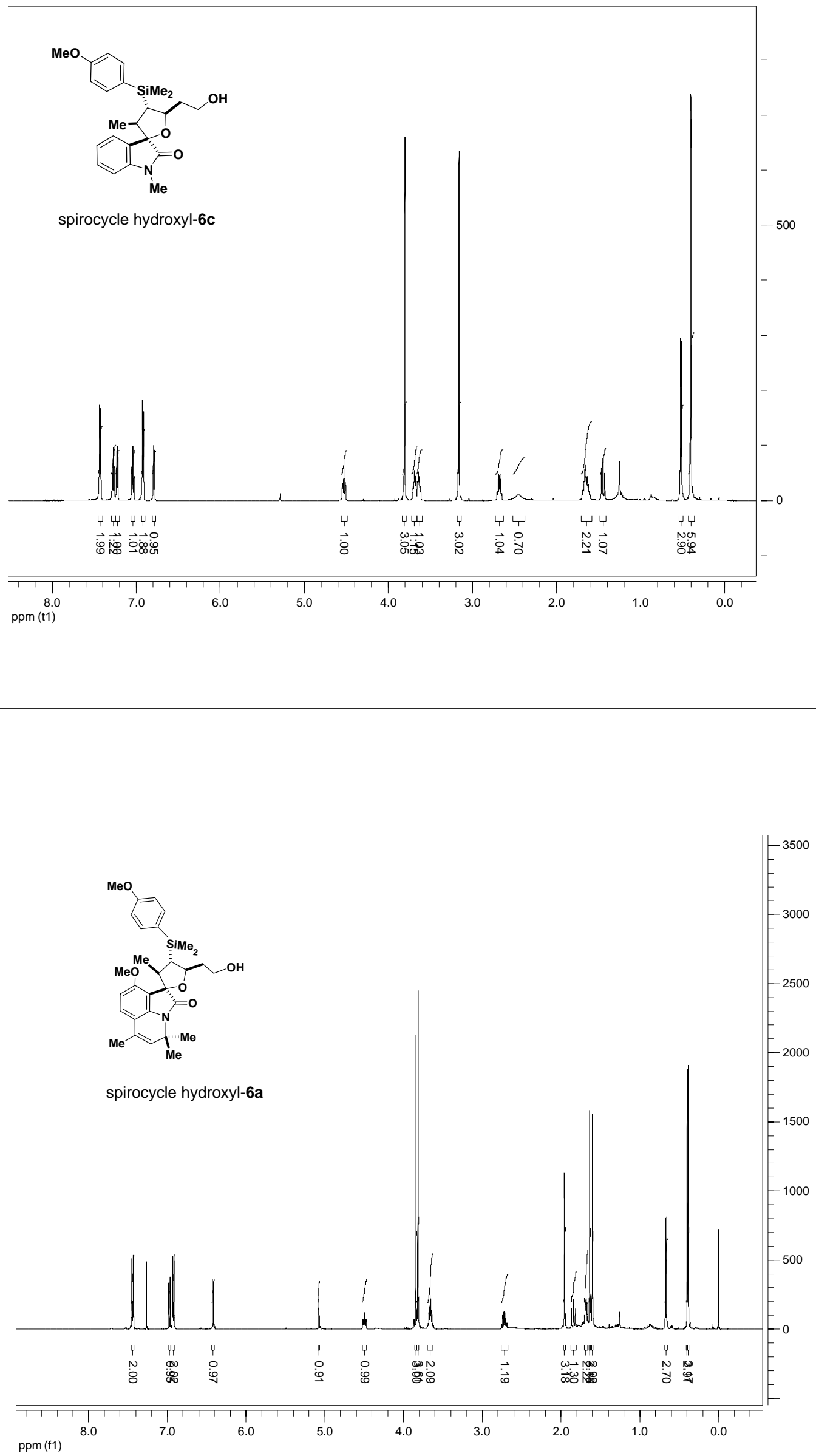


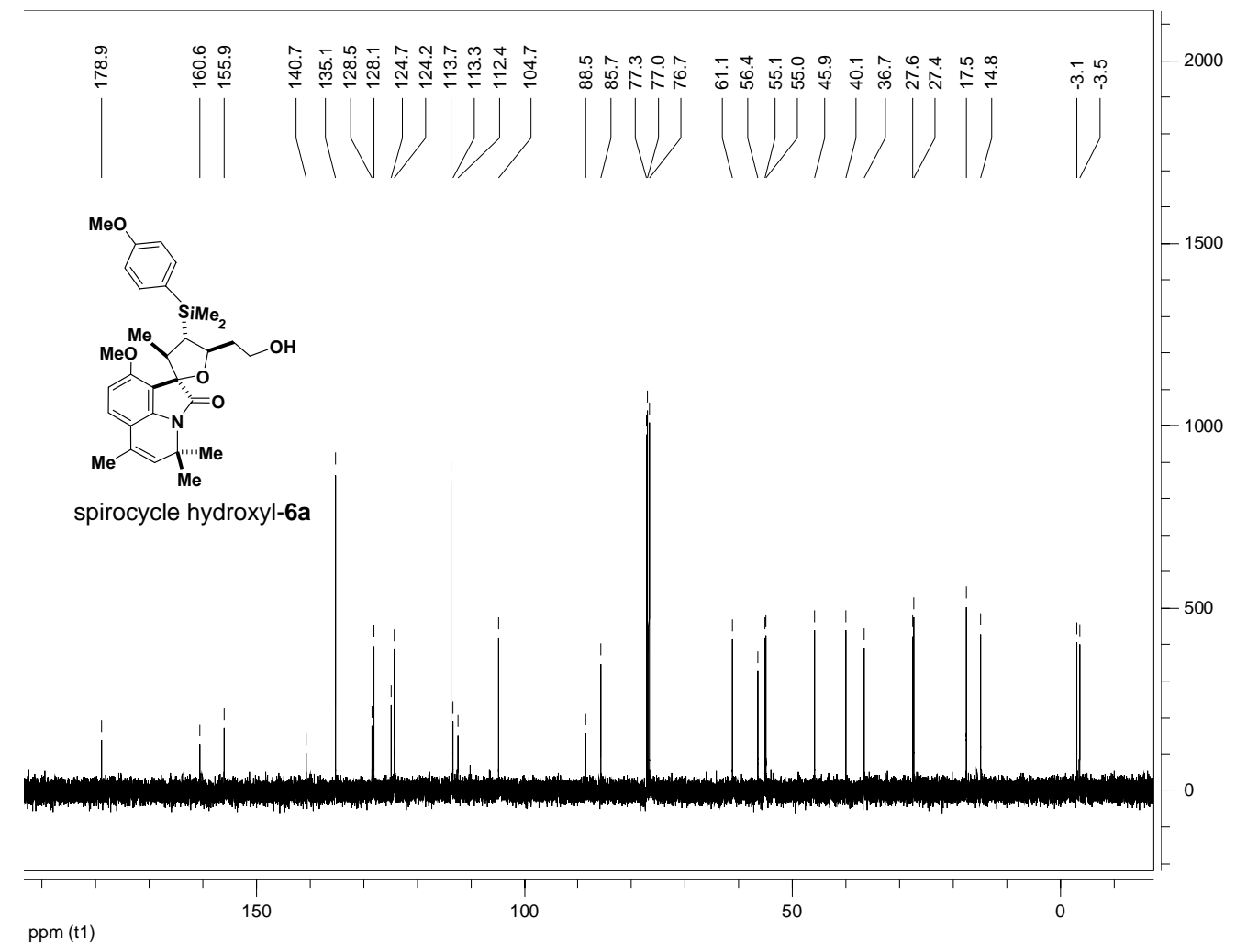

$\mathrm{MeO}$

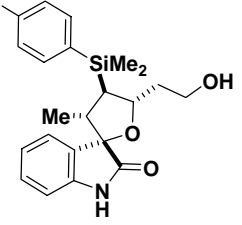

spirocycle hydroxyl-6d

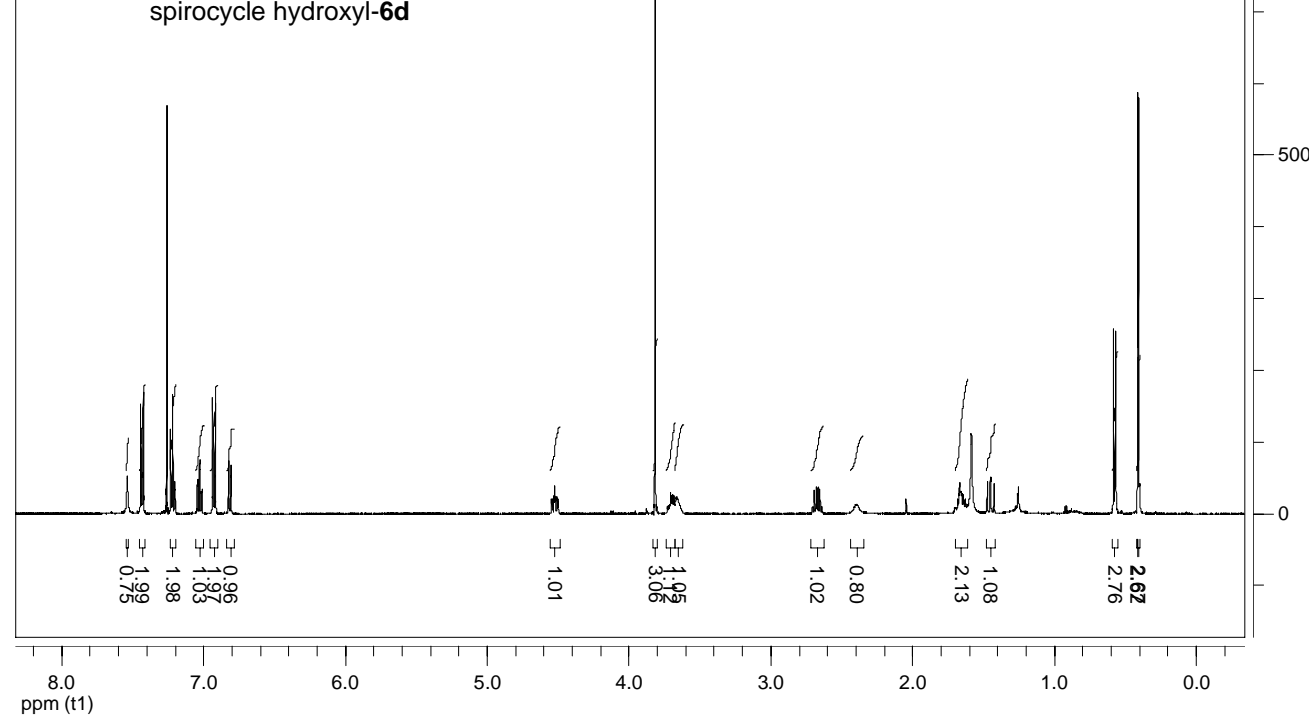



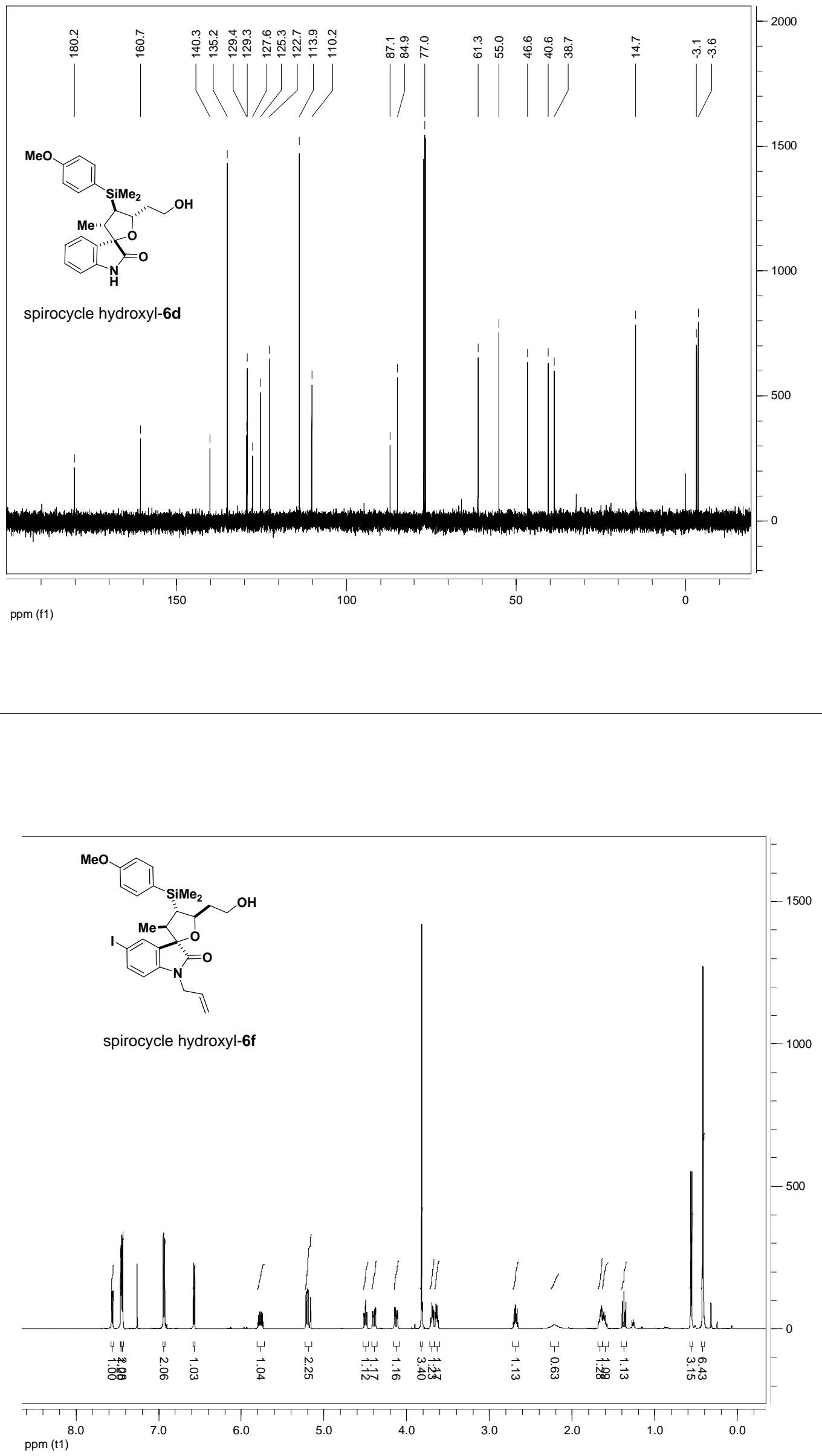

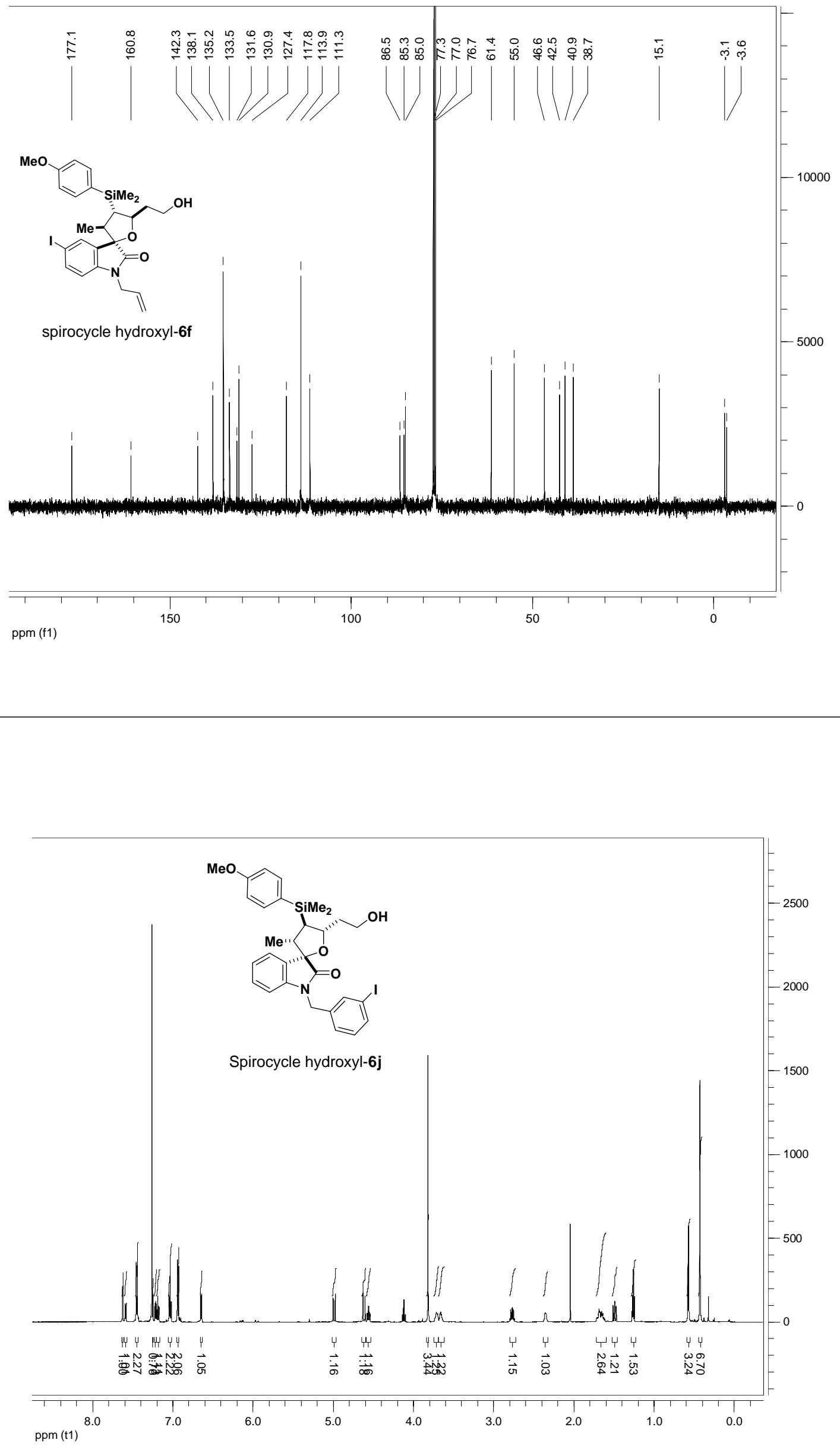

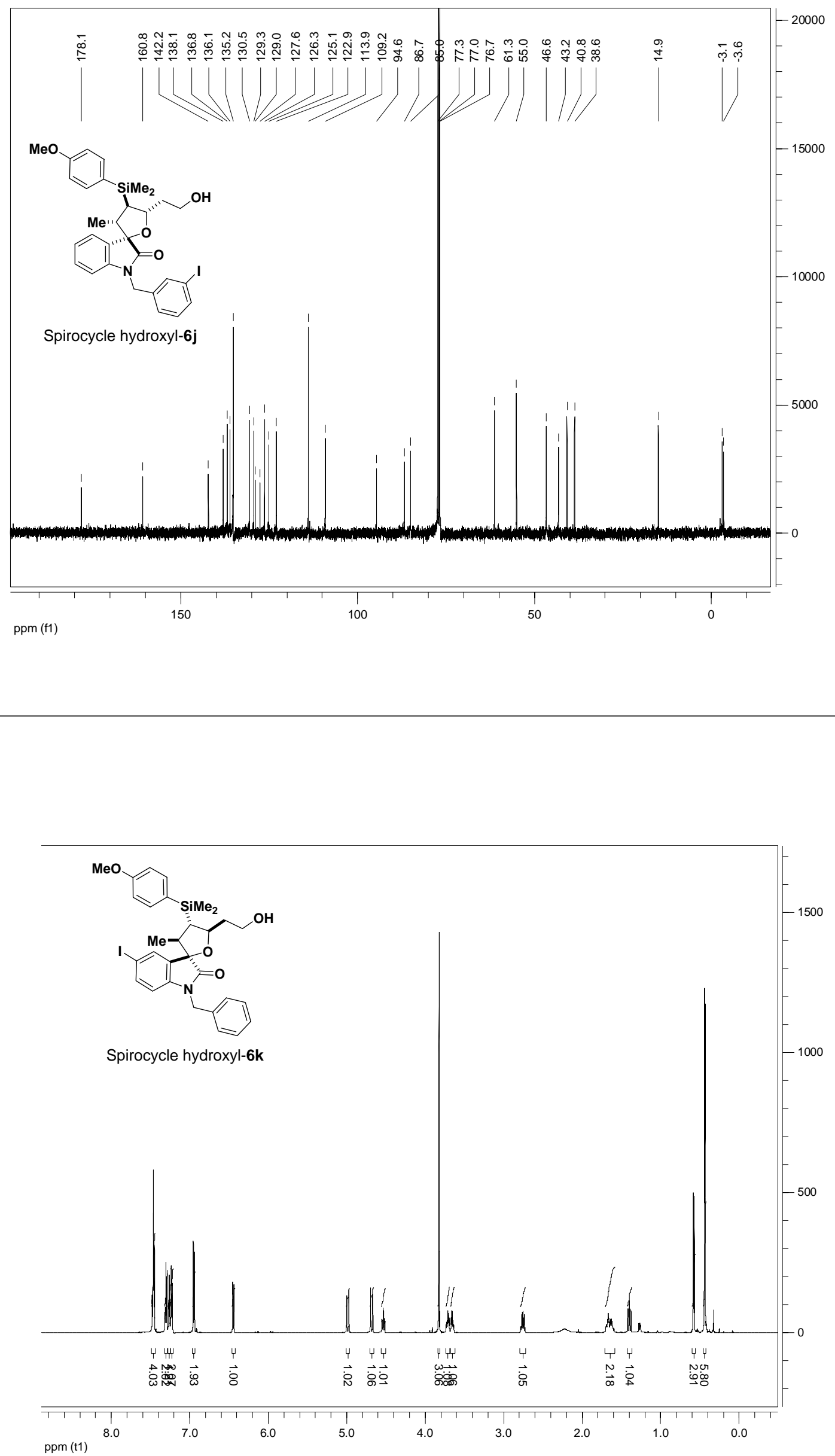

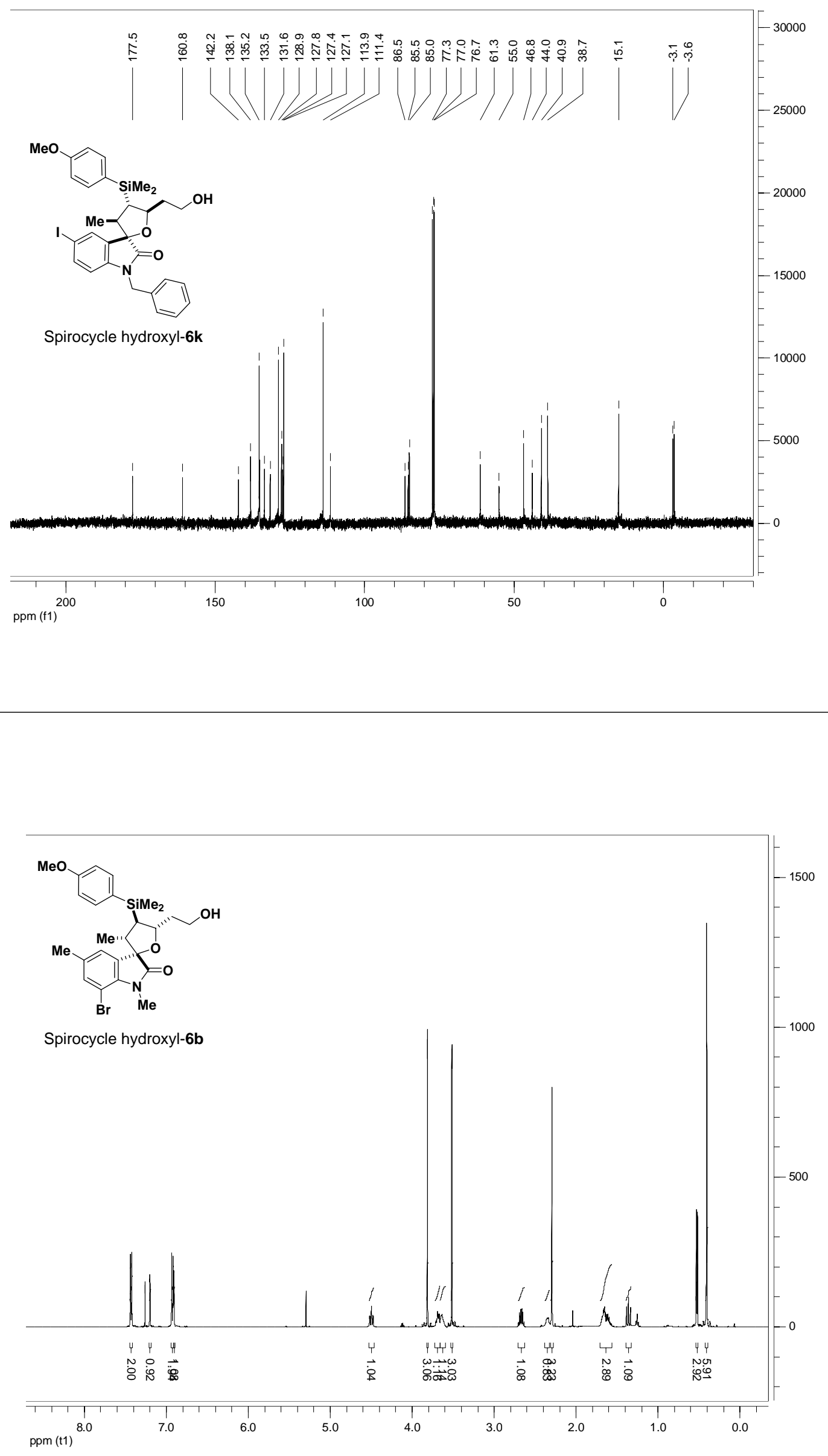


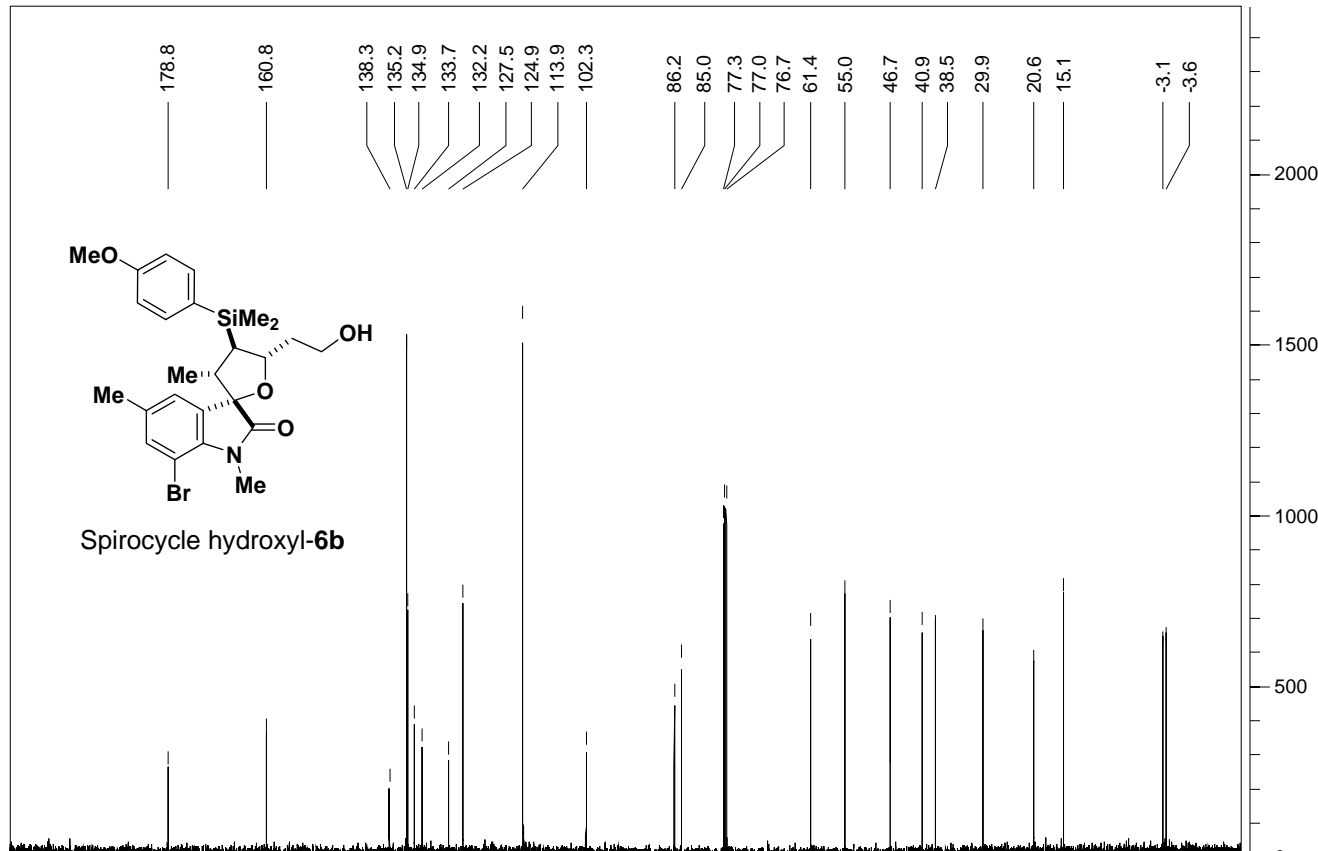

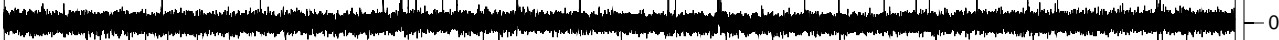
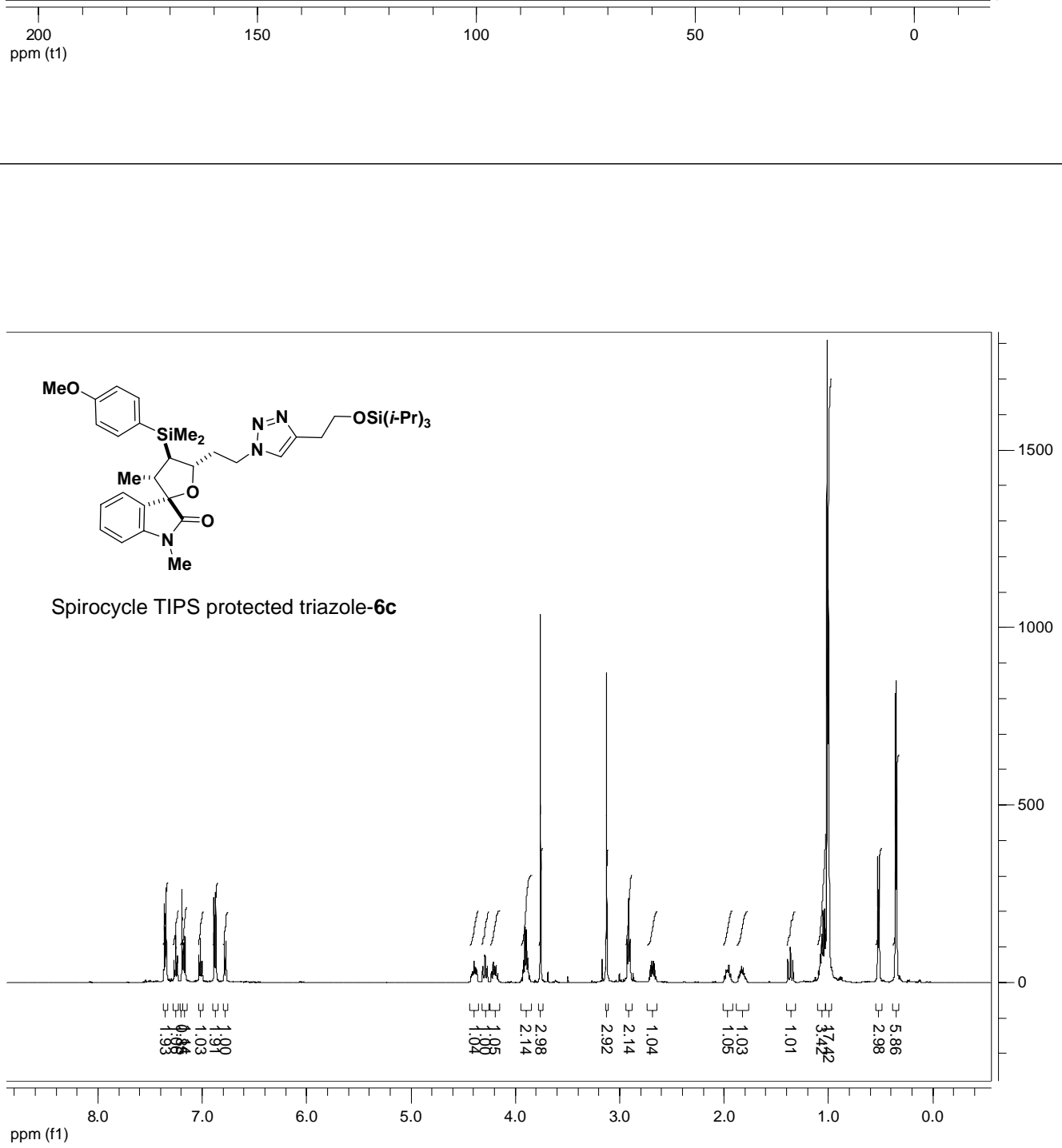

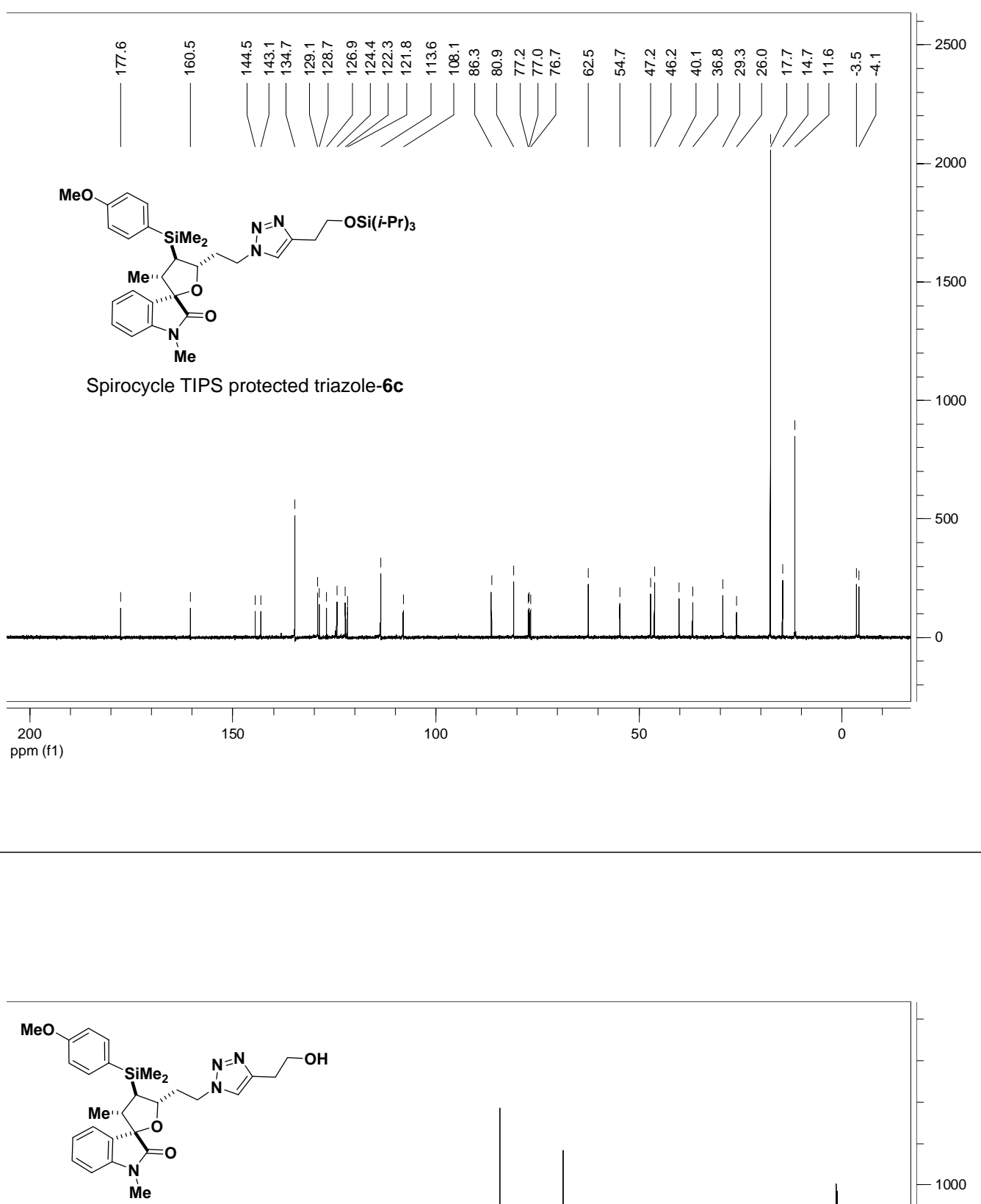

Spirocycle triazole-6c

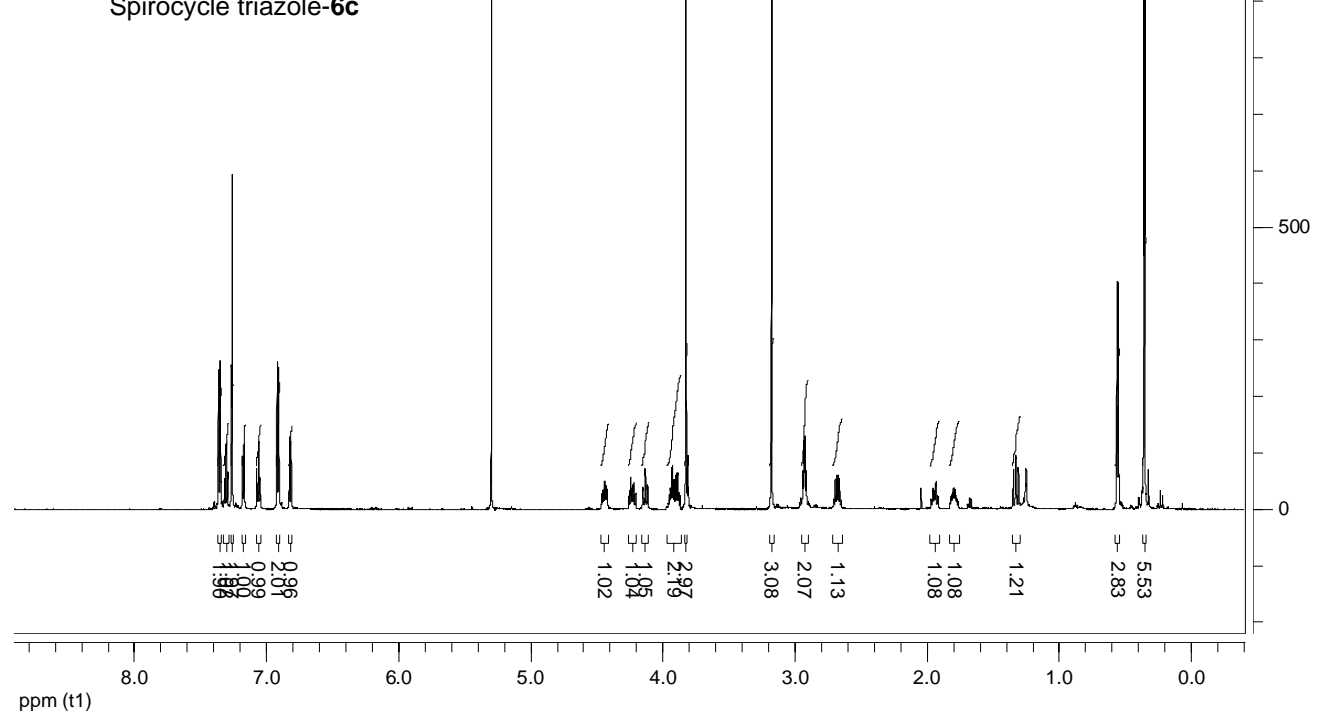



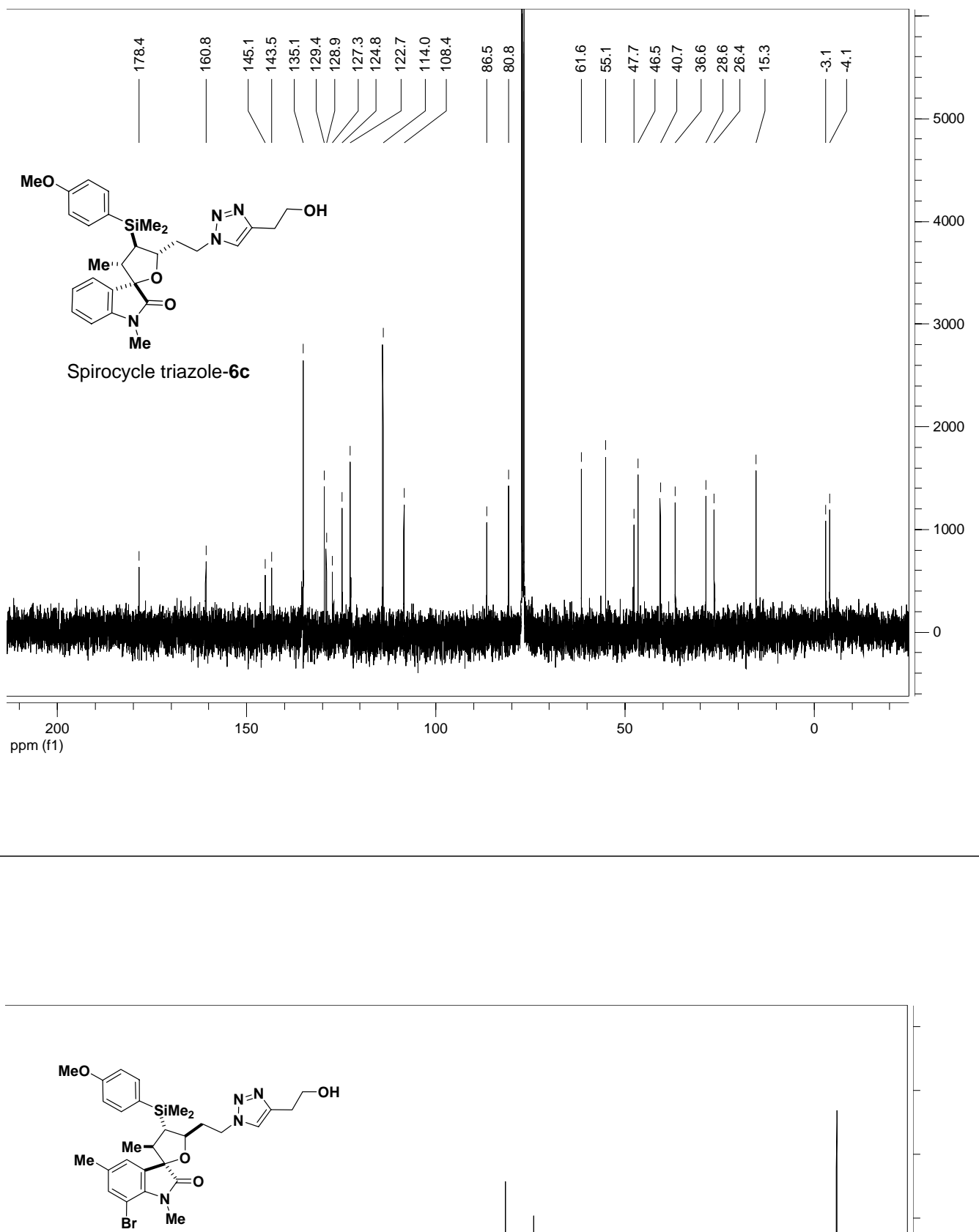

Spirocycle 11

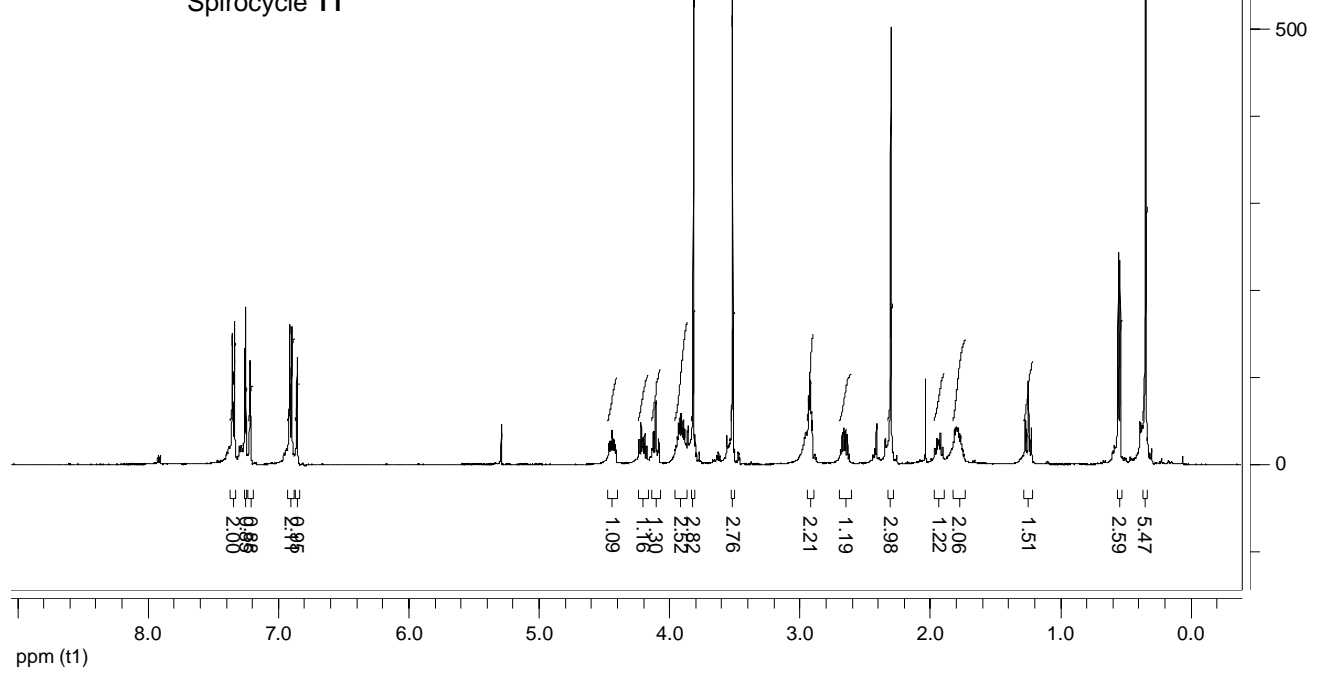



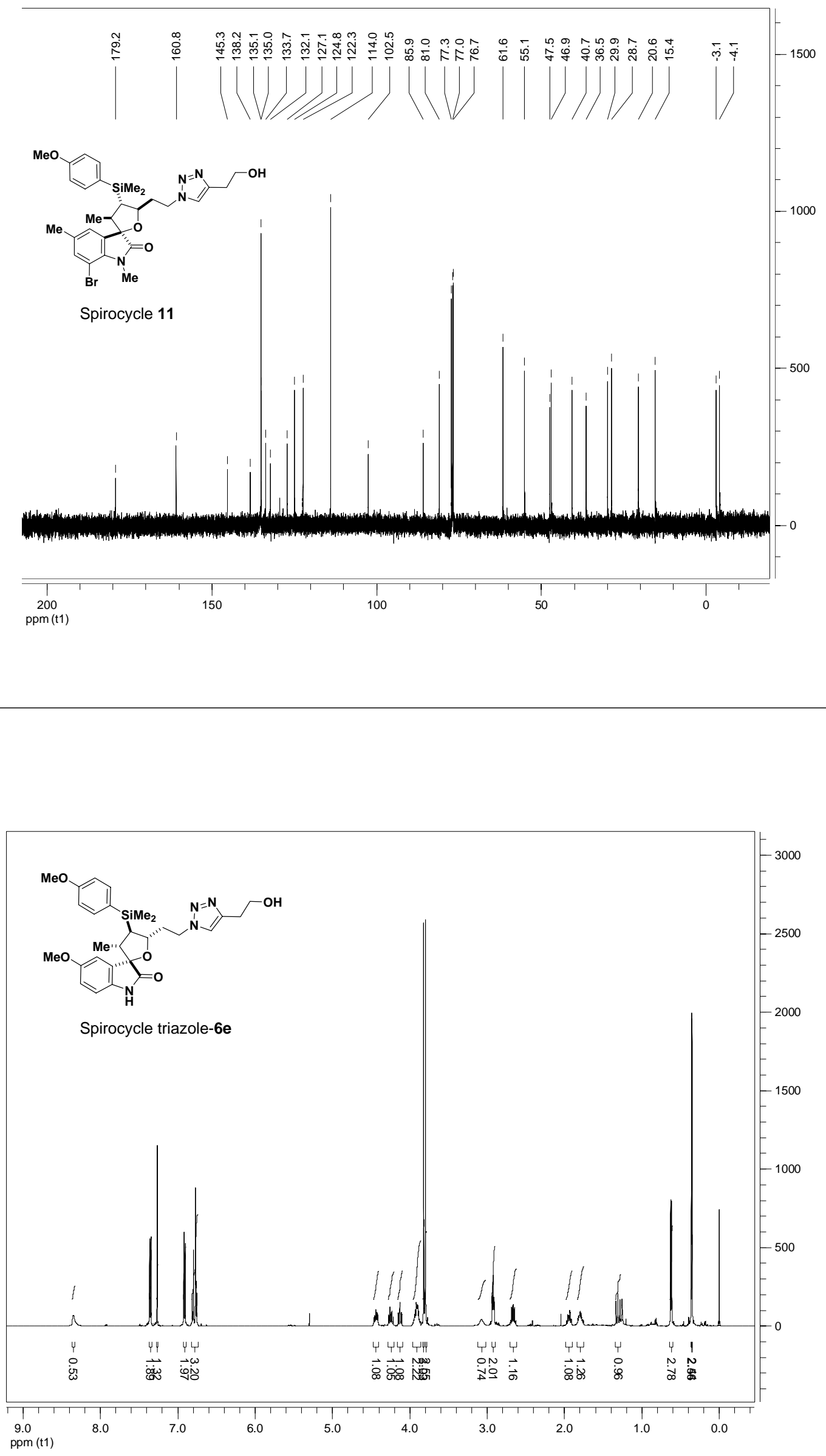

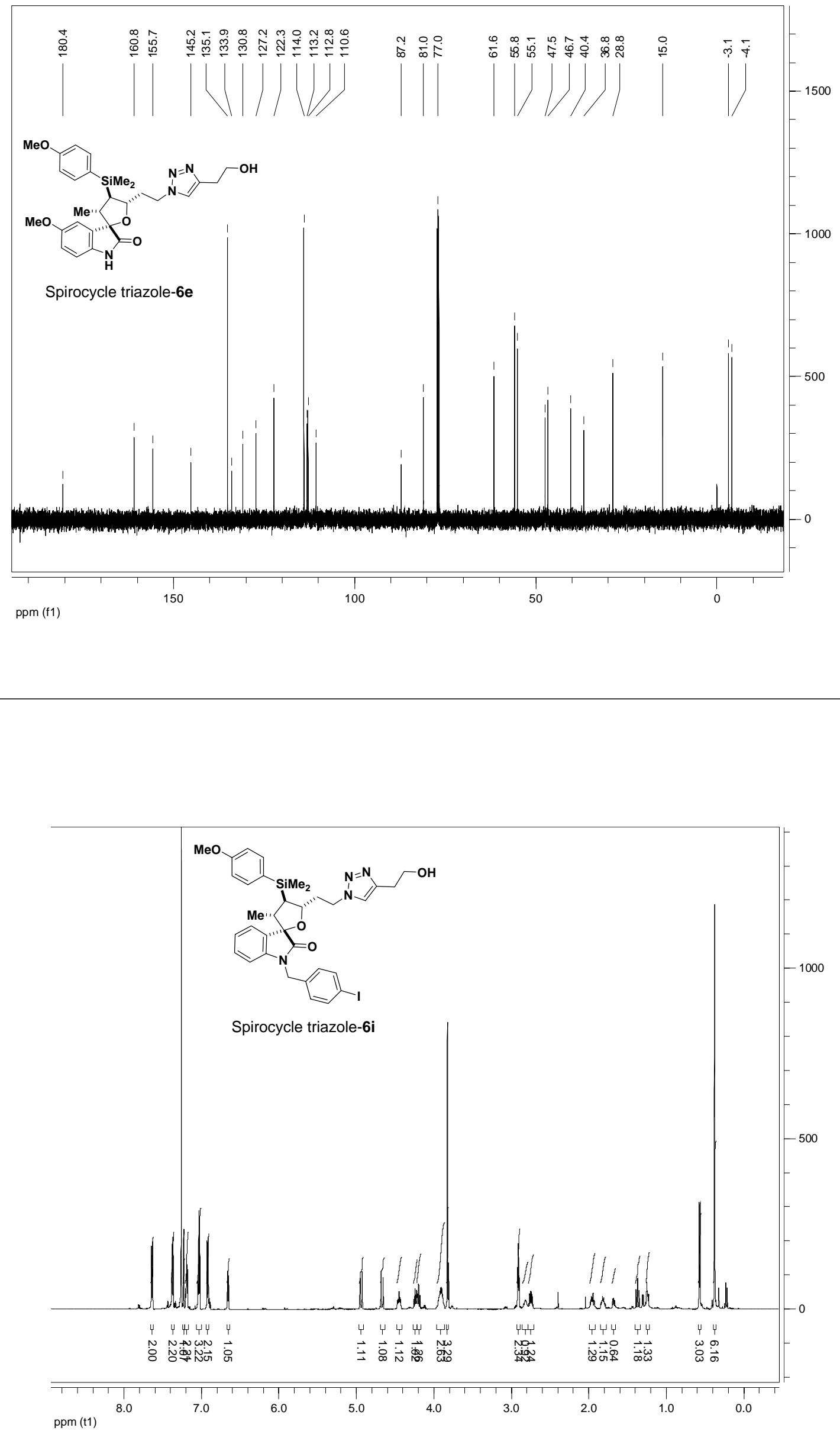

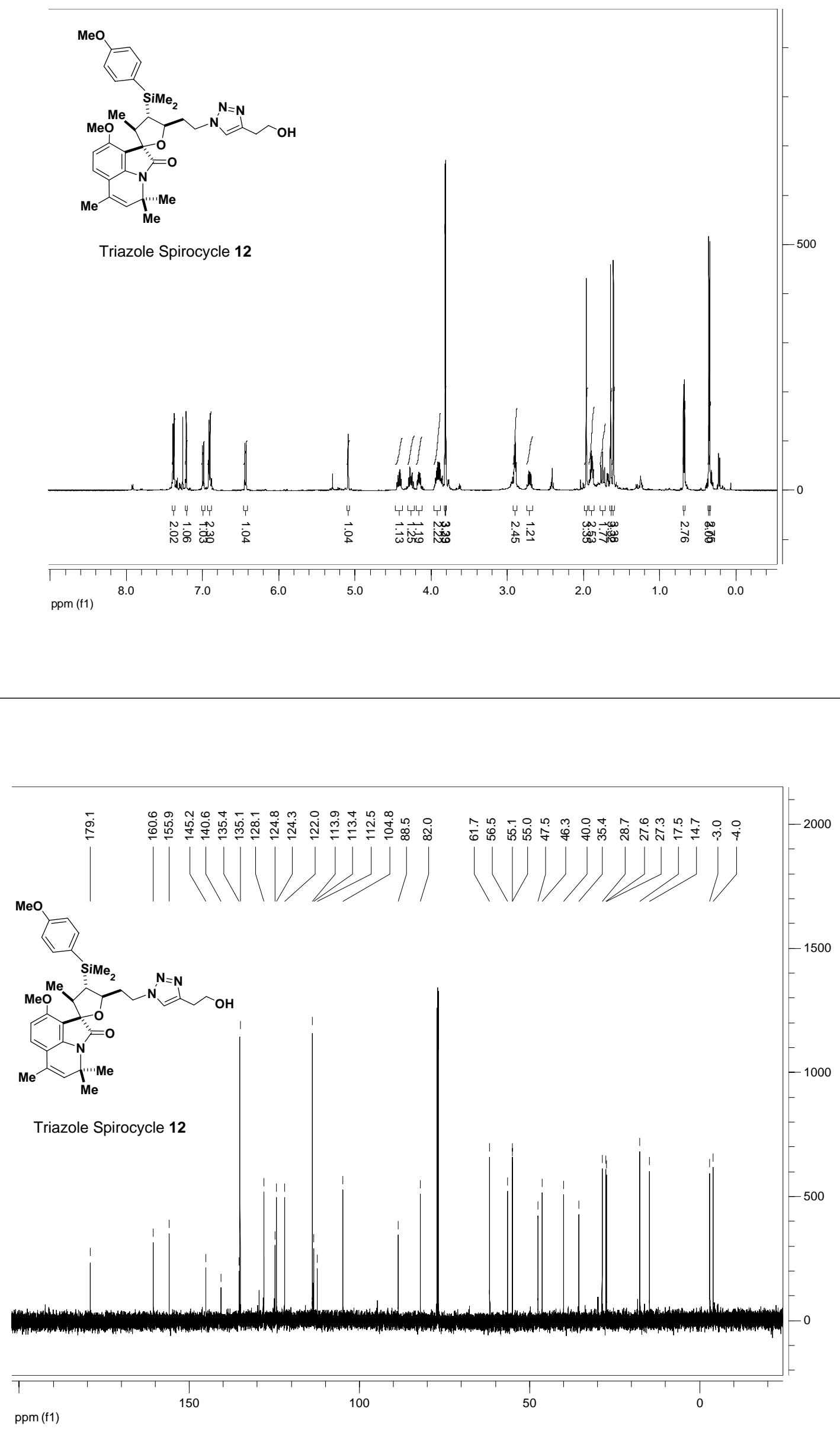

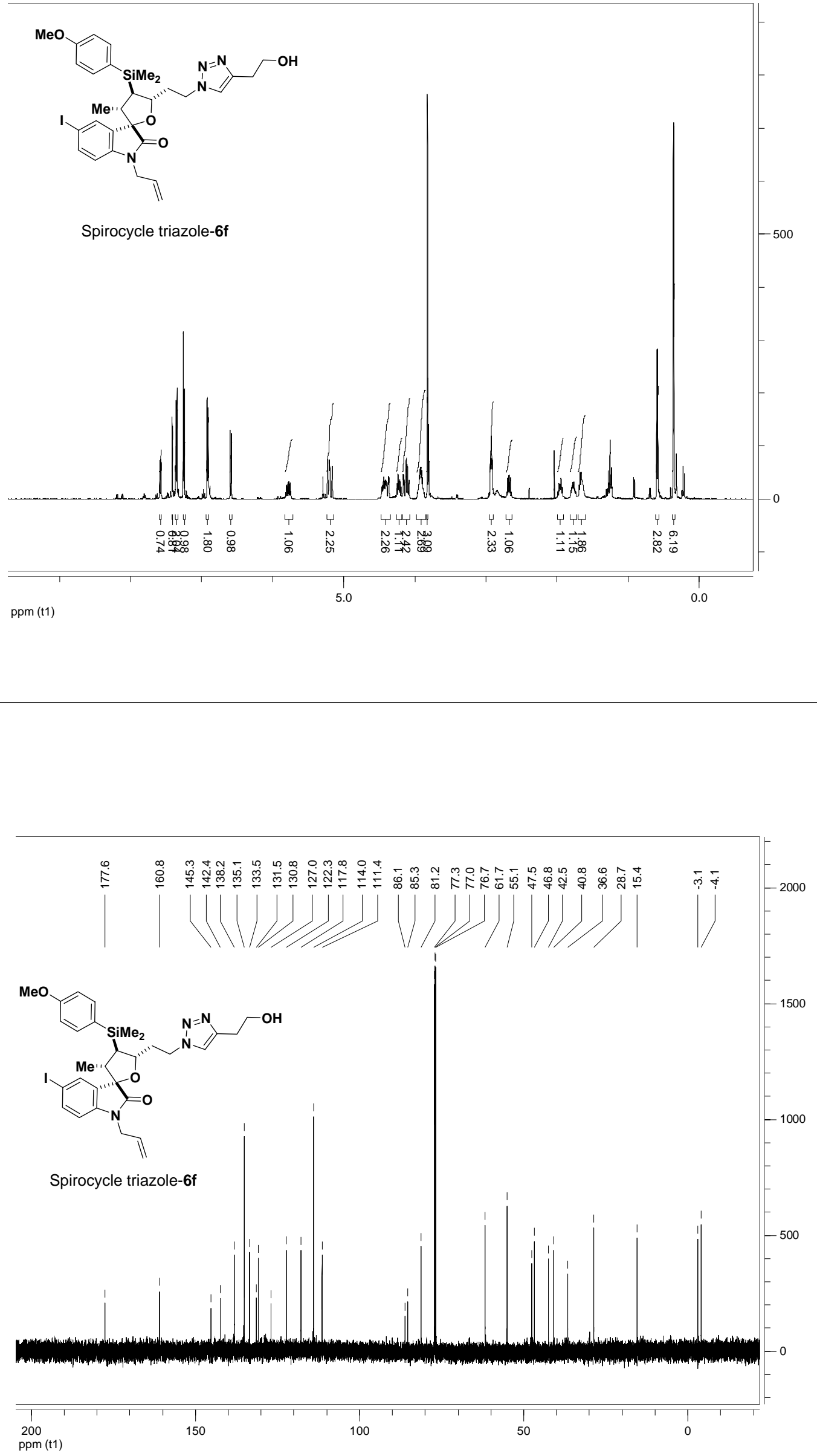

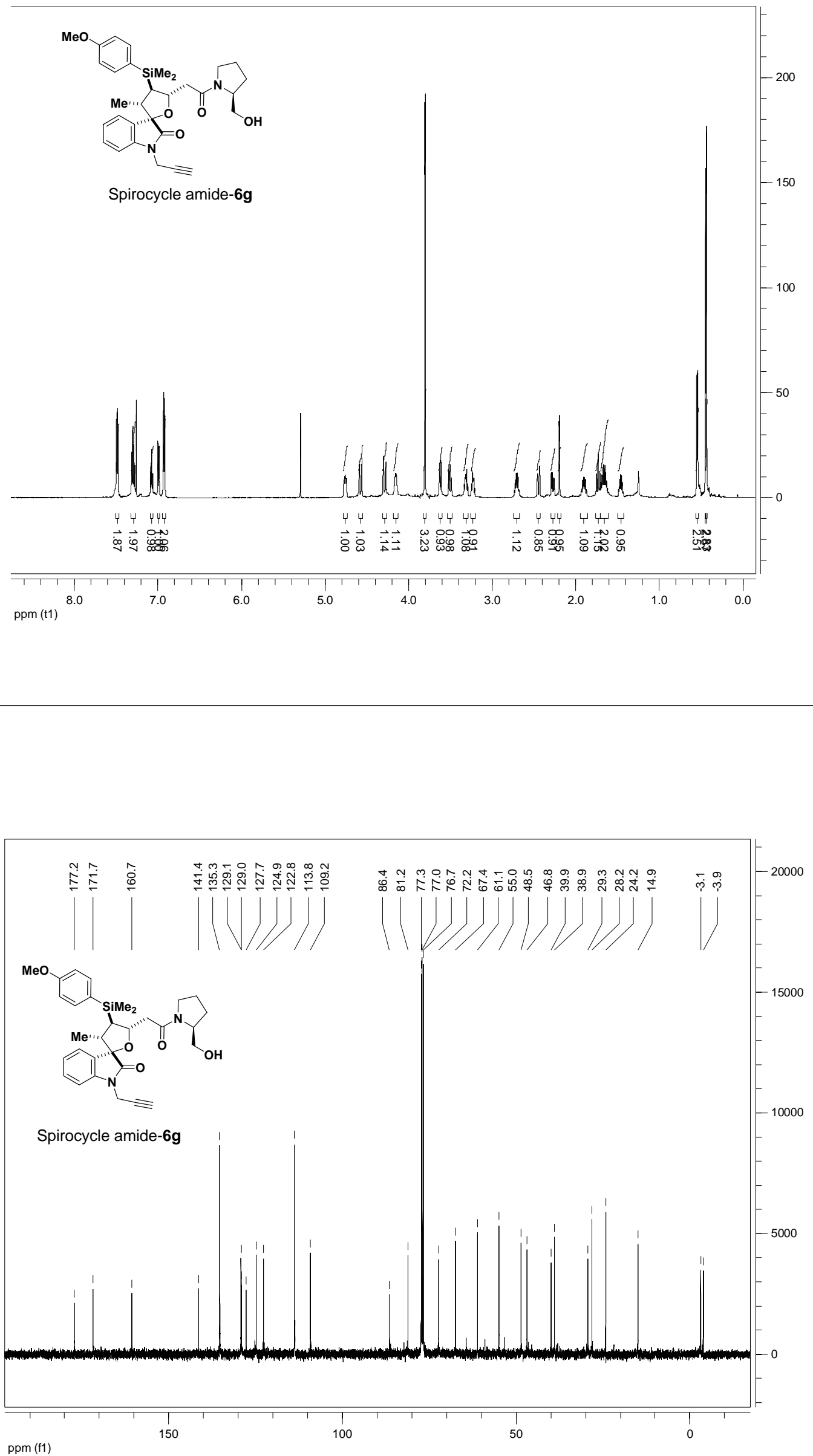

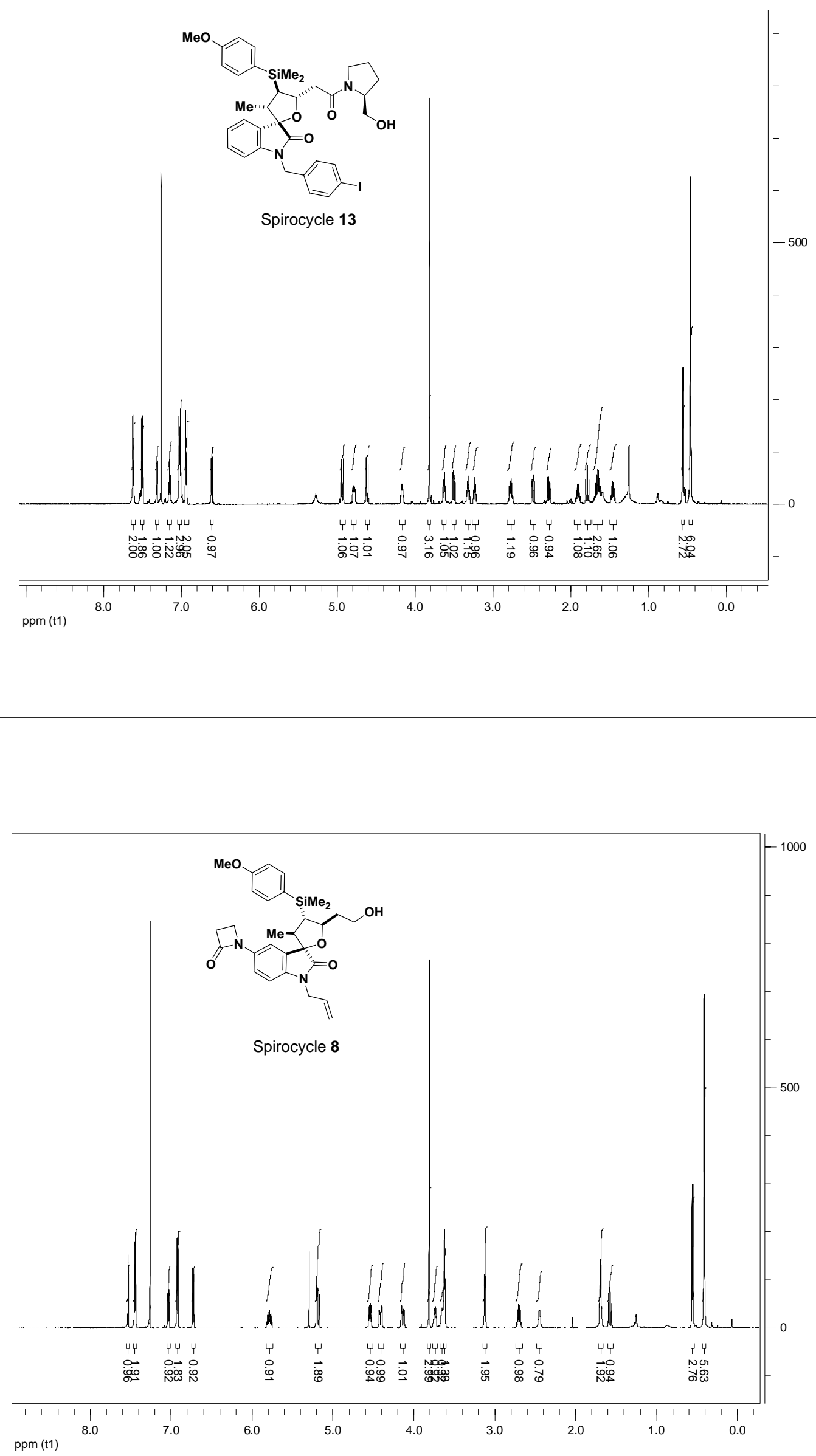

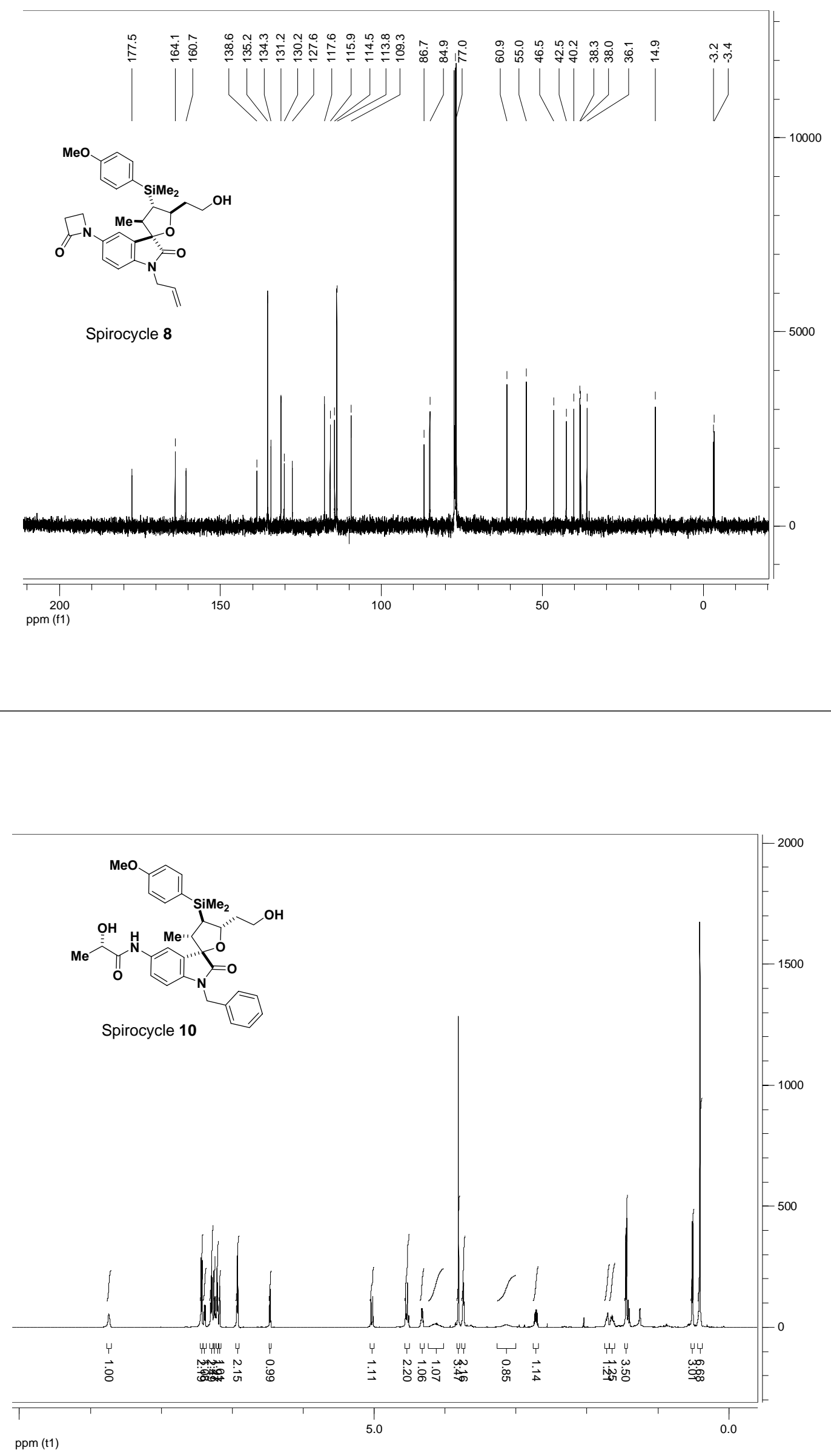


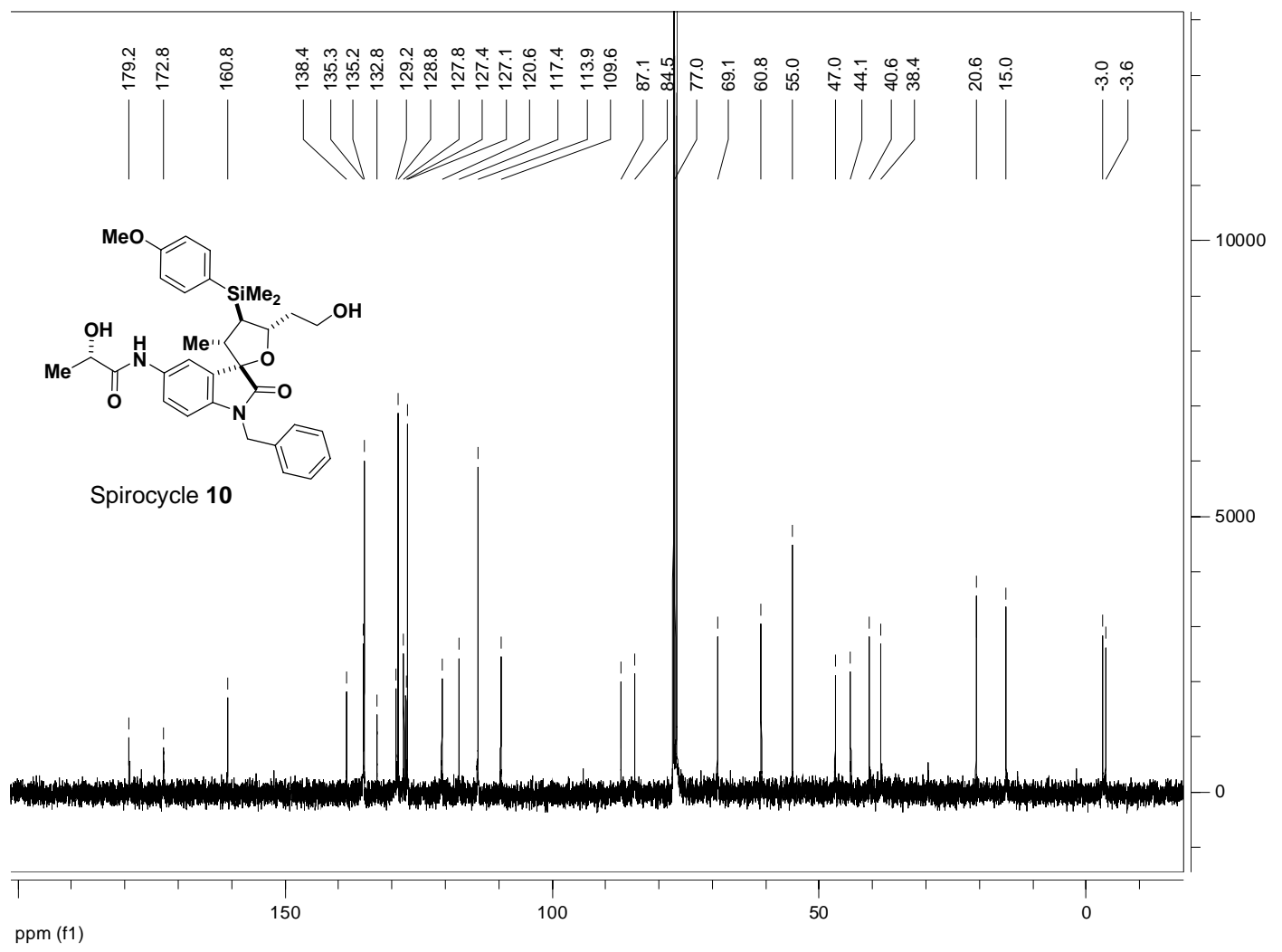

